\title{
ZUSGS
}

science for a changing world

Prepared in cooperation with the Rhode Island Coastal Resources Management Council

\section{Hydrogeology and Simulated Ground-Water Flow in the Salt Pond Region of Southern Rhode Island}

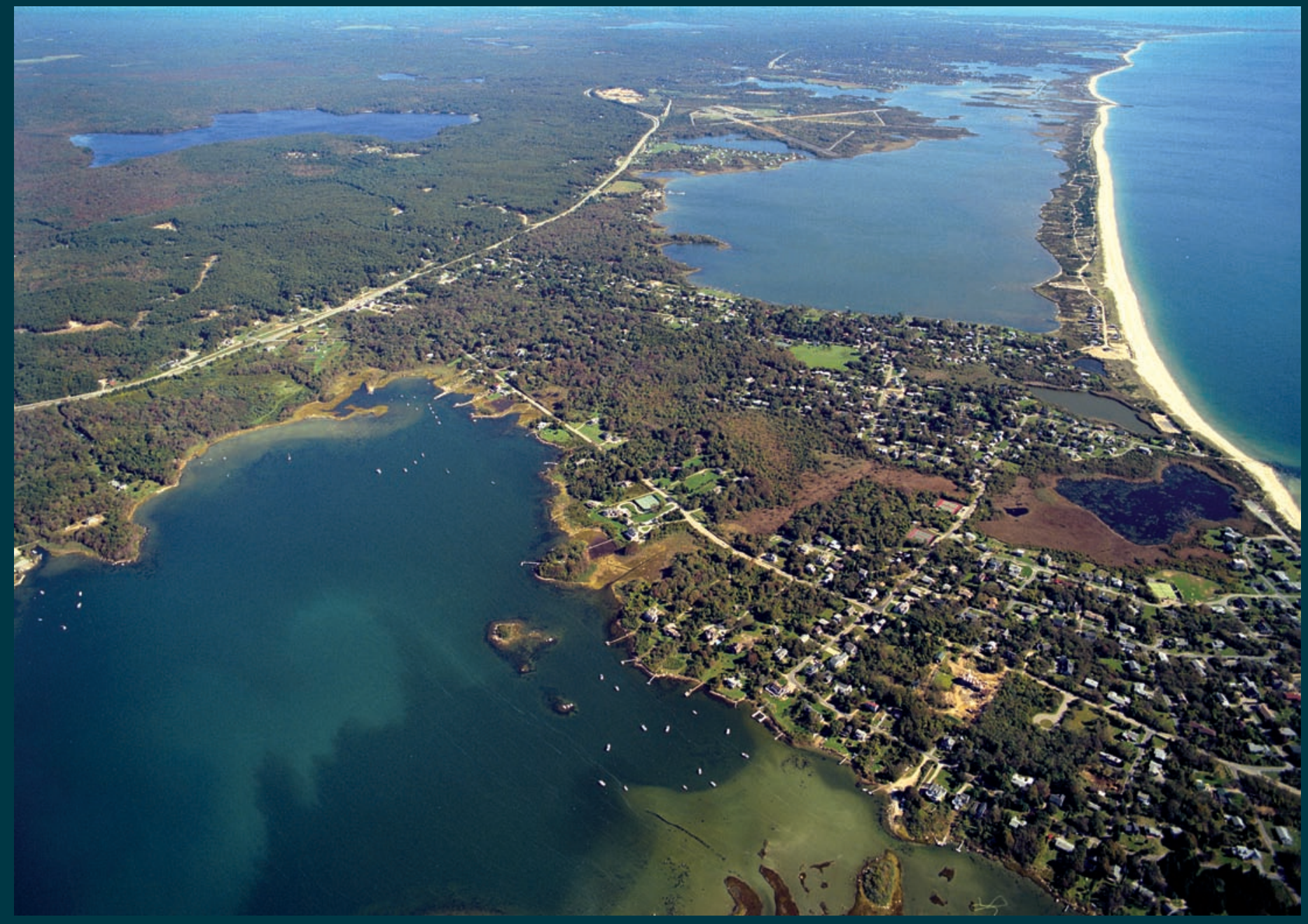

Scientific Investigations Report 2006-5271

U.S. Department of the Interior

U.S. Geological Survey 
Cover: Salt Pond region of southern Rhode Island. View is to the east with Quonochontaug Pond in the foreground and Ninigret Pond in the center. Photograph (C) Joseph R. Melanson of www.skypic.com 


\section{Hydrogeology and Simulated Ground-Water Flow in the Salt Pond Region of Southern Rhode Island}

By John P. Masterson, Jason R. Sorenson, Janet R. Stone, S. Bradley Moran', and Andrea Hougham ${ }^{2}$

1 University of Rhode Island Graduate School of Oceanography

${ }^{2}$ University of South Carolina - Columbia

Prepared in cooperation with the Rhode Island Coastal Resources

Management Council

Scientific Investigations Report 2006-5271 


\section{U.S. Department of the Interior DIRK KEMPTHORNE, Secretary}

\section{U.S. Geological Survey \\ Mark D. Myers, Director}

\section{U.S. Geological Survey, Reston, Virginia: 2007}

For product and ordering information:

World Wide Web: http://www.usgs.gov/pubprod

Telephone: 1-888-ASK-USGS

For more information on the USGS-the Federal source for science about the Earth, its natural and living resources, natural hazards, and the environment:

World Wide Web: http://www.usgs.gov

Telephone: 1-888-ASK-USGS

Any use of trade, product, or firm names is for descriptive purposes only and does not imply endorsement by the U.S. Government.

Although this report is in the public domain, permission must be secured from the individual copyright owners to reproduce any copyrighted materials contained within this report.

Suggested citation:

Masterson, J.P., Sorenson, J.R., Stone, J.R., Moran, S.B., Hougham, A., 2007, Hydrogeology and simulated groundwater flow in the Salt Pond region of southern Rhode Island: U.S. Geological Survey, Scientific Investigations Report 2006-5271, $56 \mathrm{p}$ 


\section{Contents}

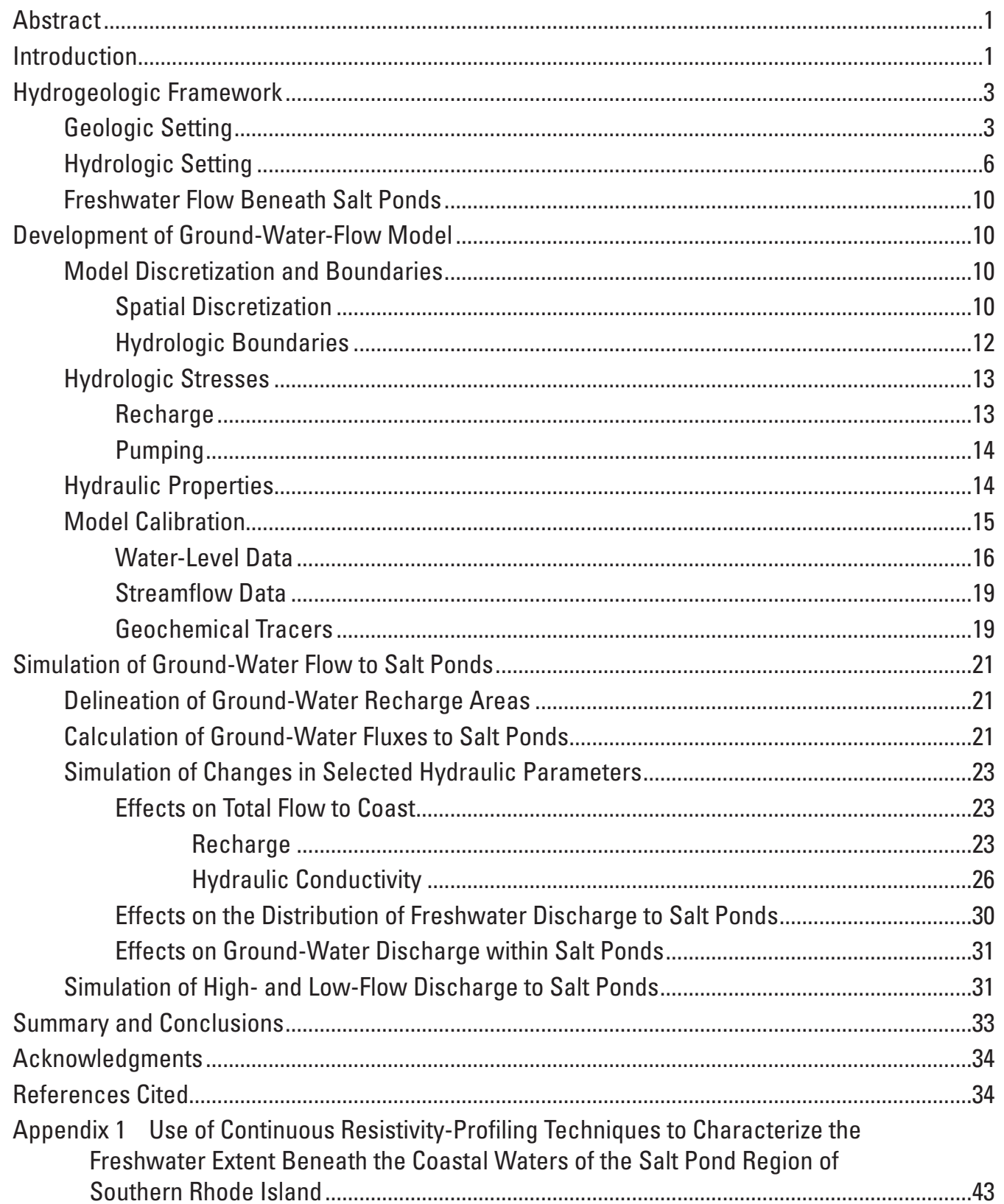




\section{Figures}

1-3. Maps showing:

1. Production wells, water-supply districts, long-term streamflow-gaging stations, and long-term observation well in the Salt Pond region of southern Rhode Island ....................2

2. Watershed boundaries of the salt ponds in the South Coastal Basin aquifer ..................4

3. Surficial geology and altitude of bedrock surface. Sections A-A' and B-B' are shown in figure 4

4. Geologic cross sections ( $A$ and $B$ ) showing deposits of southern Rhode Island 7-8

5. Generalized cross section of the Salt Pond region

6. Diagram of ground-water flow in the South Coastal Basin aquifer.......................................

7. Map showing extent and distribution of boundary conditions for ground-water-flow model of South Coastal Basin aquifer

8. Section showing model representation of geologic section B-B'

9. Graph showing long-term water levels for U.S. Geological Survey observation well Charlestown 18 (CHW-18) from 1954 through 1961

10-11. Maps showing:

10. Observation wells, ponds, and streamflow-gaging stations from which data were used for model calibration, South Coastal Basin aquifer

11. Delineation of ground-water recharge areas to production wells, streams, and salt ponds in the South Coastal Basin aquifer .....

12. Diagrams showing possible ground-water flow conditions in the South Coastal Basin aquifer where the ground-water divide is $A$, coincident with the surface-water divide; $B$, north of the surface-water divide; and $C$, south of the surface-water divide

13. Map showing changes in the model-calculated recharge area to Winnapaug Pond in response to changes in the simulated hydraulic-conductivity values representing the Charlestown moraine in the ground-water-flow model of the South Coastal Basin aquifer.

14. Graphs showing $A$, changes in model-calculated freshwater flow to Ninigret Pond in response to changes in simulated hydraulic parameters from low- to high-flow values; and $B$, changes in model-calculated freshwater flow to Green Hill Pond in response to changes in simulated hydraulic parameters from low- to high-flow values. 


\section{Tables}

1. Average pumping rates for production wells in the South Coastal Basin aquifer, southern Rhode Island, 1995-99

2. Lithology and hydraulic conductivity of lithologic units used in the ground-water-flow model of the South Coastal Basin aquifer.

3. Measured water levels for selected observation wells in the modeled area (1954-61), and the model-calculated water-level altitudes for simulated current (1995-1999) pumping and recharge conditions, South Coastal Basin aquifer

4. Water levels for selected ponds in the modeled area determined by plane-table surveys between 1953 and 1957 and reported on U.S. Geological Survey 1:24,000 topographic maps, and the model-calculated water levels for simulated current (1995-1999) pumping and recharge conditions, South Coastal Basin aquifer

5. Measured streamflows for selected locations on streams in the modeled area, and the model-calculated streamflows for simulated current (1995-1999) pumping and recharge conditions, South Coastal Basin aquifer.

6. Estimated ground-water discharge to selected salt ponds in the modeled area, and the model-calculated ground-water discharge to these ponds for simulated current (1995-1999) pumping and recharge conditions, South Coastal Basin aquifer

7. Model-calculated hydrologic budget for the South Coastal Basin aquifer under current (1995-1999) pumping and recharge conditions

8. Changes in model-calculated freshwater fluxes to selected salt ponds in response to

changes in simulated hydraulic parameters, South Coastal Basin aquifer 


\section{Conversion Factors, Datums, and Abbreviations}

\begin{tabular}{|c|c|c|}
\hline Multiply & By & To obtain \\
\hline \multicolumn{3}{|c|}{ Length } \\
\hline inch (in.) & 2.54 & centimeter $(\mathrm{cm})$ \\
\hline inch (in.) & 25.4 & millimeter $(\mathrm{mm})$ \\
\hline foot $(\mathrm{ft})$ & 0.3048 & $\operatorname{meter}(\mathrm{m})$ \\
\hline mile (mi) & 1.609 & kilometer (km) \\
\hline yard (yd) & 0.9144 & meter $(\mathrm{m})$ \\
\hline \multicolumn{3}{|c|}{ Area } \\
\hline square foot $\left(\mathrm{ft}^{2}\right)$ & 929.0 & square centimeter $\left(\mathrm{cm}^{2}\right)$ \\
\hline square foot $\left(\mathrm{ft}^{2}\right)$ & 0.09290 & square meter $\left(\mathrm{m}^{2}\right)$ \\
\hline square mile $\left(\mathrm{mi}^{2}\right)$ & 2.590 & square kilometer $\left(\mathrm{km}^{2}\right)$ \\
\hline \multicolumn{3}{|c|}{ Volume } \\
\hline million gallons (Mgal) & 3,785 & cubic meter $\left(\mathrm{m}^{3}\right)$ \\
\hline cubic inch $\left(\mathrm{in}^{3}\right)$ & 16.39 & cubic centimeter $\left(\mathrm{cm}^{3}\right)$ \\
\hline cubic foot $\left(\mathrm{ft}^{3}\right)$ & 0.02832 & cubic meter $\left(\mathrm{m}^{3}\right)$ \\
\hline \multicolumn{3}{|c|}{ Flow rate } \\
\hline foot per second (ft/s) & 0.3048 & meter per second $(\mathrm{m} / \mathrm{s})$ \\
\hline foot per day $(\mathrm{ft} / \mathrm{d})$ & 0.3048 & meter per day $(\mathrm{m} / \mathrm{d})$ \\
\hline cubic foot per second $\left(\mathrm{ft}^{3} / \mathrm{s}\right)$ & 0.02832 & cubic meter per second $\left(\mathrm{m}^{3} / \mathrm{s}\right)$ \\
\hline gallon per day (gal/d) & 0.003785 & cubic meter per day $\left(\mathrm{m}^{3} / \mathrm{d}\right)$ \\
\hline $\begin{array}{l}\text { gallon per day per square mile } \\
\qquad\left[(\mathrm{gal} / \mathrm{d}) / \mathrm{mi}^{2}\right]\end{array}$ & 0.001461 & $\begin{array}{l}\text { cubic meter per day per square } \\
\text { kilometer }\left[\left(\mathrm{m}^{3} / \mathrm{d}\right) / \mathrm{km}^{2}\right]\end{array}$ \\
\hline million gallons per day (Mgal/d) & 0.04381 & cubic meter per second $\left(\mathrm{m}^{3} / \mathrm{s}\right)$ \\
\hline inch per year (in/yr) & 25.4 & millimeter per year $(\mathrm{mm} / \mathrm{yr})$ \\
\hline
\end{tabular}

Vertical coordinate information is referenced to the National Geodetic Vertical Datum of 1929 (NGVD 29). Horizontal coordinate information is referenced to the North American Datum of 1983 (NAD 83).

Transmissivity: The standard unit for transmissivity is cubic foot per day per square foot times foot of aquifer thickness $\left[\left(\mathrm{ft}^{3} / \mathrm{d}\right) / \mathrm{ft}^{2}\right] \mathrm{ft}$. In this report, the mathematically reduced form, foot squared per day $\left(\mathrm{ft}^{2} / \mathrm{d}\right)$, is used for convenience.

Specific conductance is given in microsiemens per centimeter at 25 degrees Celsius $\left(\mu \mathrm{S} / \mathrm{cm}\right.$ at $\left.25^{\circ} \mathrm{C}\right)$.

$\begin{array}{ll}\text { CRP } & \text { continuous resistivity profiling } \\ \text { DRN } & \text { MODFLOW Drain Package } \\ \text { GWM } & \text { U.S. Geological Survey Ground-Water Map } \\ \text { NOAA } & \text { National Oceanic and Atmospheric Administration } \\ \text { PPT } & \text { parts per thousand } \\ \text { RICRMC } & \text { Rhode Island Coastal Resources Management Council } \\ \text { RIGIS } & \text { Rhode Island Geographic Information System } \\ \text { URI-GSO } & \text { University of Rhode Island Graduate School of Oceanography } \\ \text { USGS } & \text { U.S. Geological Survey } \\ \text { UWRI } & \text { United Water of Rhode Island } \\ \Omega-m & \text { ohm-meter }\end{array}$




\title{
Hydrogeology and Simulated Ground-Water Flow in the Salt Pond Region of Southern Rhode Island
}

\author{
By John P. Masterson, Jason R. Sorenson, Janet R. Stone, S. Bradley Moran' ${ }^{1}$ and Andrea Hougham²
}

\section{Abstract}

The Salt Pond region of southern Rhode Island extends from Westerly to Narragansett Bay and forms the natural boundary between the Atlantic Ocean and the shallow, highly permeable freshwater aquifer of the South Coastal Basin. Large inputs of fresh ground water coupled with the low flushing rates to the open ocean make the salt ponds particularly susceptible to eutrophication and bacterial contamination. Ground-water discharge to the salt ponds is an important though poorly quantified source of contaminants, such as dissolved nutrients.

A ground-water-flow model was developed and used to delineate the watersheds to the salt ponds, including the areas that contribute ground water directly to the ponds and the areas that contribute ground water to streams that flow into ponds. The model also was used to calculate ground-water fluxes to these coastal areas for long-term average conditions. As part of the modeling analysis, adjustments were made to model input parameters to assess potential uncertainties in model-calculated watershed delineations and in ground-water discharge to the salt ponds.

The results of the simulations indicate that flow to the salt ponds is affected primarily by the ease with which water is transmitted through a glacial moraine deposit near the regional ground-water divide, and by the specified recharge rate used in the model simulations. The distribution of the total freshwater flow between direct ground-water discharge and ground-water-derived surface-water (streamflow) discharge to the salt ponds is affected primarily by simulated stream characteristics, including the streambed-aquifer connection and the stream stage. The simulated position of the ground-water divide and, therefore, the model-calculated watershed delineations for the salt ponds, were affected only by changes in the transmissivity of the glacial moraine.

Selected changes in other simulated hydraulic parameters had substantial effects on total freshwater discharge and the distribution of direct ground-water discharge and groundwater-derived surface-water (streamflow) discharge to the salt

\footnotetext{
${ }^{1}$ University of Rhode Island Graduate School of Oceanography

${ }^{2}$ University of South Carolina - Columbia
}

ponds, but still provided a reasonable match to the hydrologic data available for model calibration. To reduce the uncertainty in predictions of watershed areas and ground-water discharge to the salt ponds, additional hydrogeologic data would be required to constrain the model input parameters that have the greatest effect on the simulation results.

\section{Introduction}

The Salt Pond region of southern Rhode Island extends from Westerly to Narragansett Bay (fig. 1). These salt ponds, or coastal lagoons, include Maschaug, Winnapaug, Quonochontaug, Ninigret, Green Hill, Trustom, Cards, Potters, and Point Judith Ponds, and form the boundary between the Atlantic Ocean and the shallow, highly permeable, freshwater aquifer of the South Coastal Basin. Large inputs of freshwater discharge coupled with low flushing rates in the salt ponds create valuable finfishing and shellfish habitats, but also make these ponds particularly susceptible to eutrophication and bacterial contamination (Olsen and Lee, 1984).

Ground-water discharge to the salt ponds is an important although poorly quantified source of dissolved nutrients and contaminants that can lead to significant detrimental effects on this economically and ecologically important coastal region. Ground-water quality can be rapidly degraded by individual on-site waste-disposal systems, particularly in permeable glacial sediments; a close correlation exists in a number of coastal communities between population density and concentrations of nitrate in ground water (Johannes, 1980; Nixon and others, 1982; Sewell, 1982; Persky, 1986; Giblin and Gaines, 1990).

As recently as 1995, nearly 40 percent of the Salt Pond region was undeveloped; however, as the population in this region continues to increase at a rate double the statewide average, open space continues to be developed for residential use (Ernst and others, 1999). Managing the cumulative effects of the input of chemical (nutrients, contaminants) and biological (bacteria) substances derived from on-site waste-disposal systems to the salt ponds requires an understanding of the areas that contribute ground water to these coastal receiving waters and the streams that flow into them. 


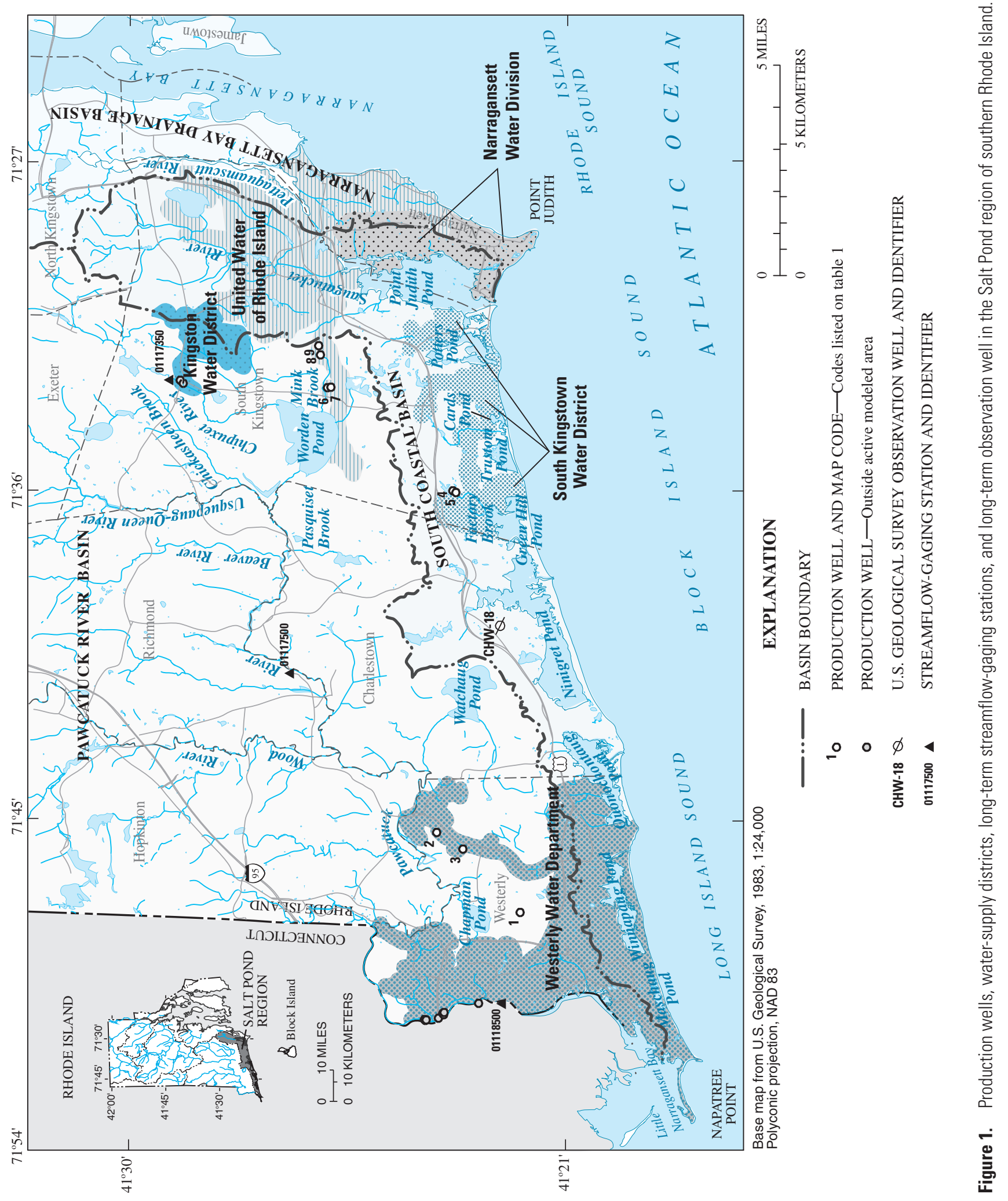


The Rhode Island Coastal Resources Management Council (RICRMC), which has regulatory authority over the salt ponds and their associated coastal resources, has taken a comprehensive, watershed-based approach to protect the ecosystems in the Salt Pond region by balancing future development with protection of coastal resources. This approach requires delineating the areas that contribute ground-water flow and associated contaminants to the salt ponds, and to the streams that flow into them.

Two methods have been used in the past to delineate the watersheds to the salt ponds. The first was to delineate the areas that contribute ground-water recharge to the ponds on the basis of the ground-water-flow directions drawn from the water-table contours published for each of the U.S. Geological Survey (USGS) quadrangle maps in the study area from 1954 through 1961 (Hahn, 1959; Johnson and Marks, 1959; Lang and others, 1960; LaSala and Hahn, 1960; LaSala and Johnson, 1960; Johnson, 1961a, 1961b). This first method included a synthesis of these quadrangle-scale contour maps into a regional water-table map extending from Point Judith to Ninigret Ponds (Grace and Kelley, 1981; H.E. Johnson, U.S. Geological Survey, written commun., 1981). Watersheds to several of the larger salt ponds (Ninigret, Green Hill, Trustom, Cards, Potters, and Point Judith Ponds) were then delineated on the basis of these ground-water contours, and the total freshwater discharge to these ponds was calculated on the basis of an assumed aquifer recharge rate specified for these watersheds (Grace and Kelley, 1981). The accuracy of this method was limited by the lack of water-level data and the uncertainty of the water-table contours in the northern parts of watersheds in and around the upland areas between the Pawcatuck River and the salt ponds (fig. 1).

The second method used to delineate the watersheds to the salt ponds was to identify the topographic divides of the watersheds. In the river basins north of the South Coastal Basin, the ground-water divide is assumed to coincide with the surface-water divide, and both are defined by the topographic divide. This method also was applied to the watersheds in the South Coastal Basin (fig. 2) (Ernst and others, 1999); however, the water-table contours used in the first method suggest that the assumption that the ground-water and surface-water divides are coincident is not always valid in this basin.

In response to the ever-increasing development pressures and growing concerns over the detrimental effects of eutrophication to coastal resources, the USGS, in cooperation with the RICRMC, began a 2-year investigation in 2003 to improve the regional understanding of the hydrogeologic framework and ground-water flow in the Salt Pond region of southern Rhode Island. A characterization of the hydrogeologic framework of the glacial sediments provided the information needed to develop a preliminary ground-water-flow model for the area south of the Pawcatuck River from Napatree Point to Point Judith (fig. 1), which includes includes Maschaug, Winnapaug, Quonochontaug, Ninigret, Green Hill, Trustom, Cards, Potters, and Point Judith Ponds.
This report provides an overview of the hydrogeology of the Salt Pond region of southern Rhode Island and the development of the ground-water-flow model, which was based on this hydrogeologic framework. The ground-water-flow model was used to delineate the watersheds that contribute ground-water discharge to the salt ponds (direct ground-water discharge) and the streams that flow into them (ground-waterderived surface-water discharge), and to calculate groundwater fluxes to these coastal areas for long-term average conditions. As part of the modeling analysis, adjustments were made to model-input parameters, within reasonable bounds, to assess potential changes in the watershed delineations and in ground-water discharge to the salt ponds. This report also describes the use of the ground-water-flow model for (1) evaluating the appropriateness of the existing map-drawn watersheds of the salt ponds (Grace and Kelley, 1981; Ernst and others, 1999); (2) providing estimates of ground-water fluxes to the salt ponds; and (3) identifying reasonable uncertainties in these model-calculated flux values in light of the limited hydrogeologic data available for the study area.

\section{Hydrogeologic Framework}

Characterizing ground-water flow and freshwater discharge to the Salt Pond region of southern Rhode Island requires an understanding of the hydrogeologic processes that affect how freshwater enters, flows through, and leaves the aquifer of the South Coastal Basin. The accuracy of numerical models developed to simulate ground-water flow and coastal discharge depends to a large extent on how well these processes are characterized and represented in these models.

\section{Geologic Setting}

The southern Rhode Island coastal region is dominated by thick glacial deposits that overlie an irregular bedrock surface formed by seaward-sloping bedrock valleys and intervening ridges. Postglacial sediments locally overlie glacial deposits. In the salt-pond areas, Holocene barrier beach and tidal-delta sands and lagoonal fine-grained sediments overlie coarser-grained glacial deposits. Paleozoic bedrock beneath the study area consists predominantly of Narragansett Pier granite and other granitic rock units (Hermes and others, 1994). The present-day westerly course of the Pawcatuck River is a glacial drainage diversion caused by deposition of the Charlestown Moraine and its associated meltwater deposits across the valleys of formerly south-flowing rivers. Glacial deposits are as much as $300 \mathrm{ft}$ thick where the moraine crosses the deepest parts of bedrock valleys. The bedrock-surface contours shown on figure 3 were constructed by using all available well data and offshore data from high-resolution seismicreflection profiles (Needell and Lewis, 1984).

The generalized distribution of glacial deposits shown on figure 3 is modified from a digital compilation available from 

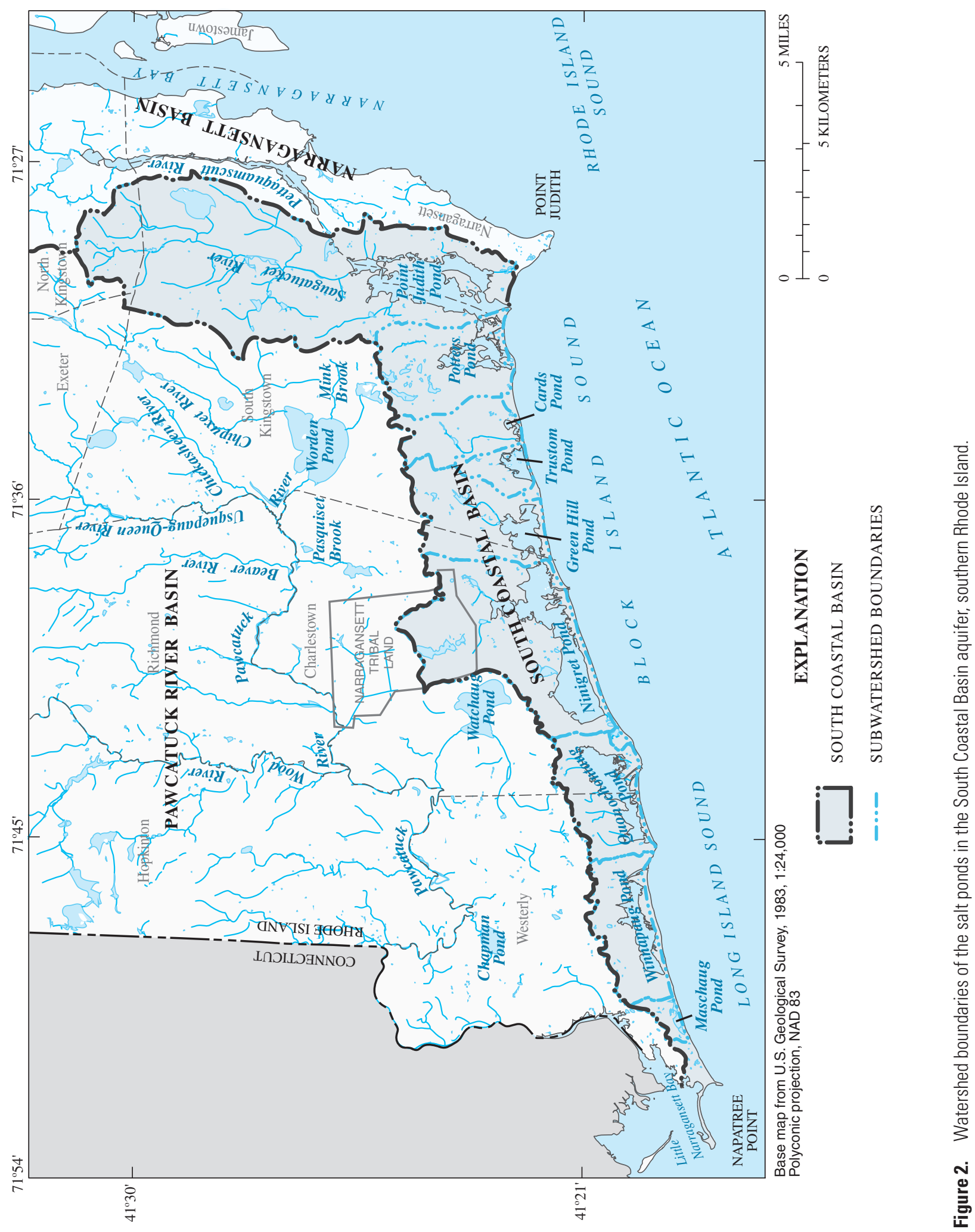


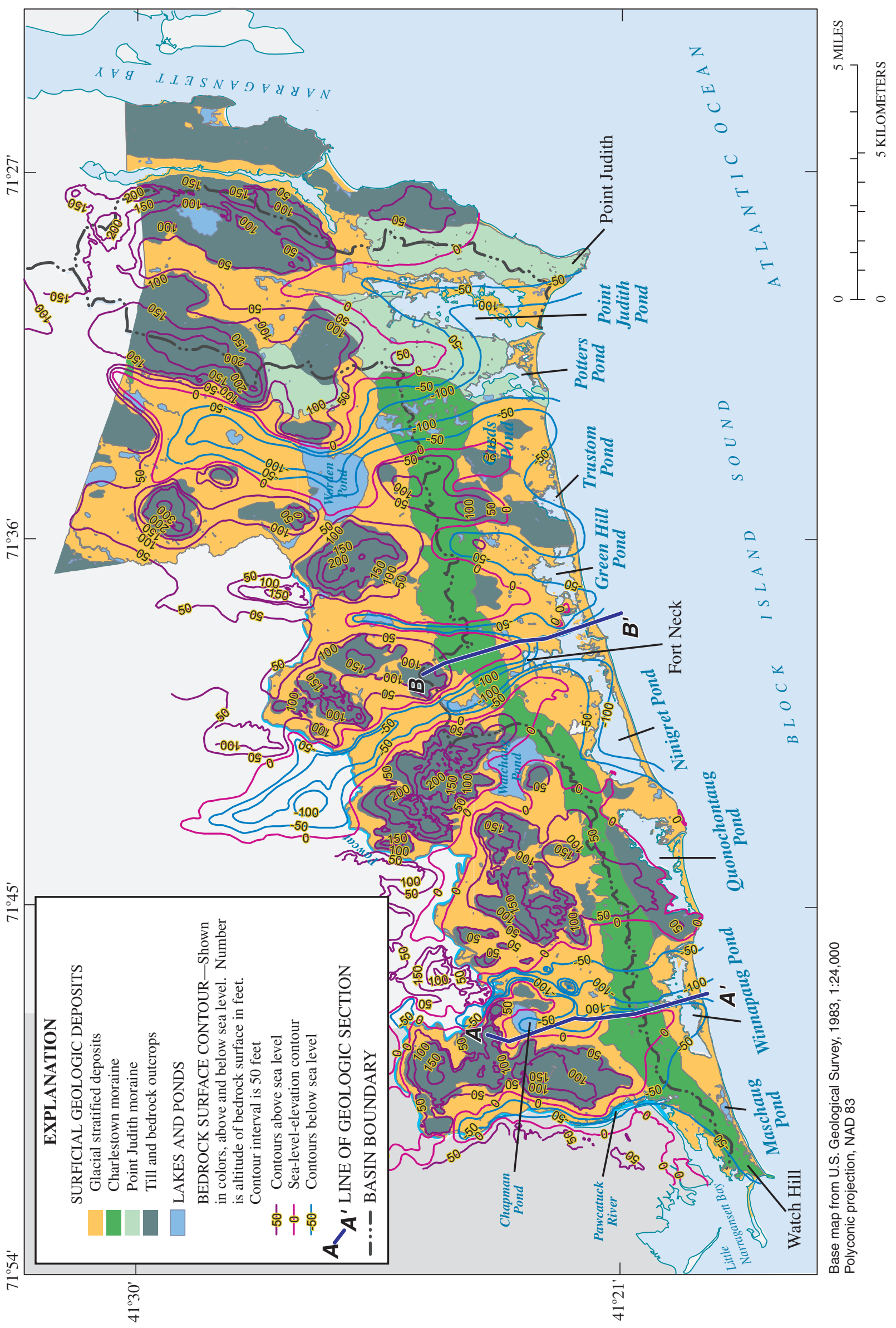

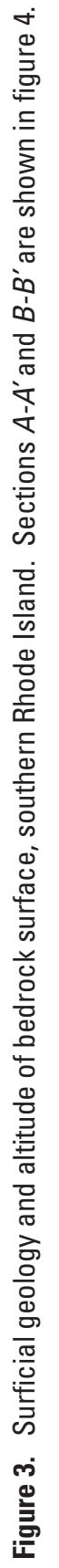


the Rhode Island Geographic Information System (RIGIS) website. Available metadata for this coverage is minimal, but geologic contacts between till, moraine, and glacial stratified deposits are represented as mapped by Kaye (1960), LaSala and Hahn (1960), LaSala and Johnson (1960), and Schafer (1961, 1965). Glacial deposits include subglacially deposited till, glacial-meltwater deposits, and morainal deposits of the Charlestown, Point Judith, and other recessional moraines.

The distribution of surficial materials that lie between the land surface and the bedrock surface is shown on cross-sections $A-A^{\prime}$ and $B-B^{\prime}$ (figs. $4 \mathrm{a}, \mathrm{b}$ ). The cross sections illustrate the characteristic vertical succession of glacial till, glacialmeltwater deposits, and postglacial deposits. Most of these materials are deposits of the last two continental ice sheets that covered New England during the middle and late Pleistocene. Most were laid down during the advance and retreat of the last (late Wisconsinan) ice sheet, which reached its terminus on Long Island, NY, about 21,000 years ago and was retreating northward through the southern Rhode Island coastal area by about 19,500 years ago (Stone and Borns, 1986; Boothroyd and others, 1998).

Glacial till in the study area was deposited directly by glacier ice and is characterized as a nonsorted, nonlayered, relatively compact mixture of sand, silt, and clay with variable amounts of stones and large boulders. Till blankets the bedrock surface in most places and is generally less than 20 $\mathrm{ft}$ thick. In many places within the area shown as "till and bedrock outcrops" (fig. 3), till is absent and bedrock is present at the land surface.

The Charlestown Moraine is a WSW-ENE trending, hummocky linear ridge extending from Watch Hill to just west of Point Judith Pond (fig. 3). The morainal ridge forms the surface-water drainage divide between northerly flowing streams tributary to the Pawcatuck River and small, southerly flowing streams that discharge into the coastal salt ponds. The moraine is a thick and complex mixture of sediments including sandy ablation till and intermixed sands and gravel.

The Charlestown Moraine, described by Kaye (1960), consists of belts of uneven topography containing narrow ridges (called ice-fracture fillings and colluvial ramparts) and mounds. The mounds tend to be flat-topped and underlain by sandy foreset bedding. Shallow exposures in the moraine commonly reveal sandy, bouldery ablation till. No deep exposures have been observed. Some logs of deep wells in the moraine indicate it is cored by stratified sand and gravel. Alternative explanations for emplacement of the Charlestown Moraine are discussed in Boothroyd and others (1998).

The Point Judith Moraine, described by Schafer (1961), is a lower relief landform trending NNW-SSE and intersects the Charlestown Moraine west of Point Judith Pond. This moraine may be slightly younger in age than the Charlestown Moraine.

Glacial-meltwater deposits that consist of glaciofluvial and glaciolacustrine gravel, sand, silt, and clay cover most of the coastal area. South of the Charlestown Moraine, these sediments were deposited by meltwater streams that issued from the ice margin and flowed into a large glacial lake that occupied Block Island Sound and Narragansett Bay (Peck and McMaster, 1991; Boothroyd and others, 1998). Large glaciofluvial outwash plains grade southward to deltaic deposits that interfinger with glaciolacustrine silts and clays offshore. The lacustrine deposits have been mapped in Block Island Sound by using high-resolution seismic reflection profiles (Needell and Lewis, 1984).

The glaciofluvial outwash-plain deposits consist primarily of very coarse cobble-boulder gravel. Delta topset beds are also gravelly and overlie sandy delta foreset beds. The surfaces of these deposits contain many ice-block depressions; parts of the salt ponds have developed in these large (kettle) depressions. North of the Charlestown Moraine, meltwater deposits are predominantly sand and gravel ice-marginal deltas and fine sand and silt lake-bottom sediments laid down in several glacial lakes impounded behind the moraine.

Postglacial deposits overlie glacial deposits and include floodplain alluvium along rivers and streams and organic peat and muck (swamp deposits) in low-lying closed depressions. In the salt-pond areas, barrier-beach and tidal-delta sands are present on the seaward sides; these sands interfinger with and locally overlie lagoonal fine-grained sediment on the landward sides of the salt ponds. Beach and tidal-delta sands and the lagoonal fine-grained sediments overlie freshwater marsh deposits of peat and muck, which is postglacial organic fill in former kettle-hole depressions (fig. 5) (Dillon, 1970; Boothroyd and others, 1985).

\section{Hydrologic Setting}

For the purpose of this investigation, the South Coastal Basin aquifer includes the glacial stratified deposits south of the Pawcatuck River; these deposits include those that underlie the towns of Westerly, Charlestown, Narragansett, and South Kingstown. The aquifer ranges in thickness from less than 10 $\mathrm{ft}$ in the upland till areas to more than $100 \mathrm{ft}$ in the bedrock valleys (namely, the Fort Neck area of Ninigret Pond) (fig. 3). This aquifer is underlain by crystalline bedrock, which is not considered part of the South Coastal Basin aquifer because of its low transmissivity.

The South Coastal Basin aquifer system is bounded laterally by surface-water bodies and underneath by crystalline bedrock. The Pawcatuck and Chipuxet Rivers form the northern and westernmost extent of the aquifer, and the Pettaquamscutt River and Narragansett Bay form the easternmost extent of the aquifer (fig. 1). Ground water also discharges to the streams that flow to the salt ponds south of the Charlestown Moraine. These streams can contribute substantial amounts of freshwater discharge to the salt ponds (Grace and Kelley, 1981; Nixon and others, 1982; Ernst, 1996). The southernmost extent of the South Coastal Basin aquifer is beneath the coastal waters of southern Rhode Island; however, ground-water discharge to this coastal area is poorly understood.

The primary source of freshwater to the South Coastal Basin aquifer is from precipitation. Precipitation at the 


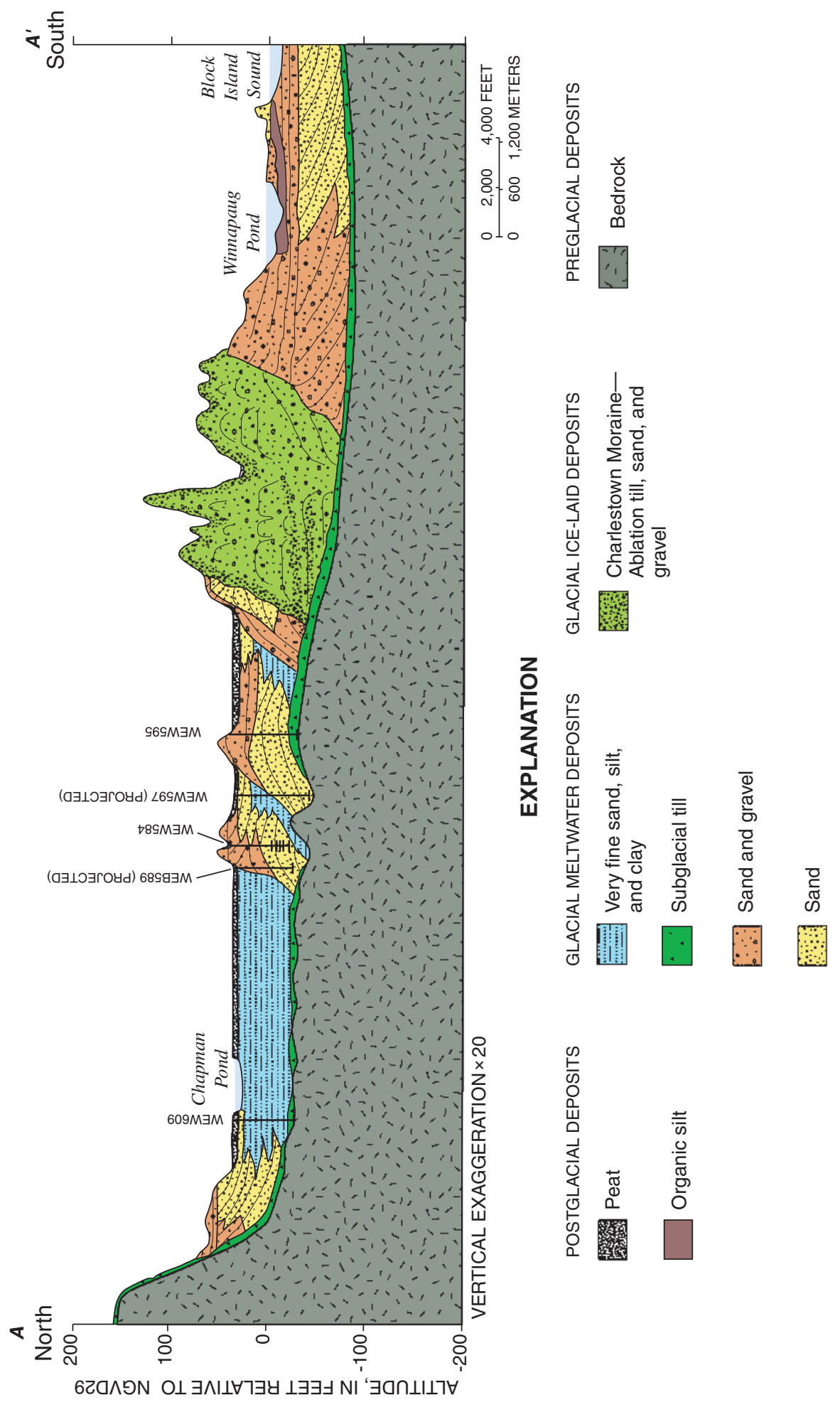

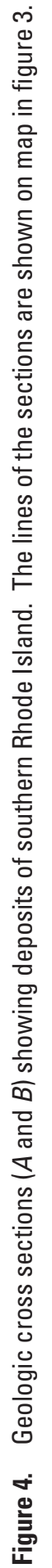




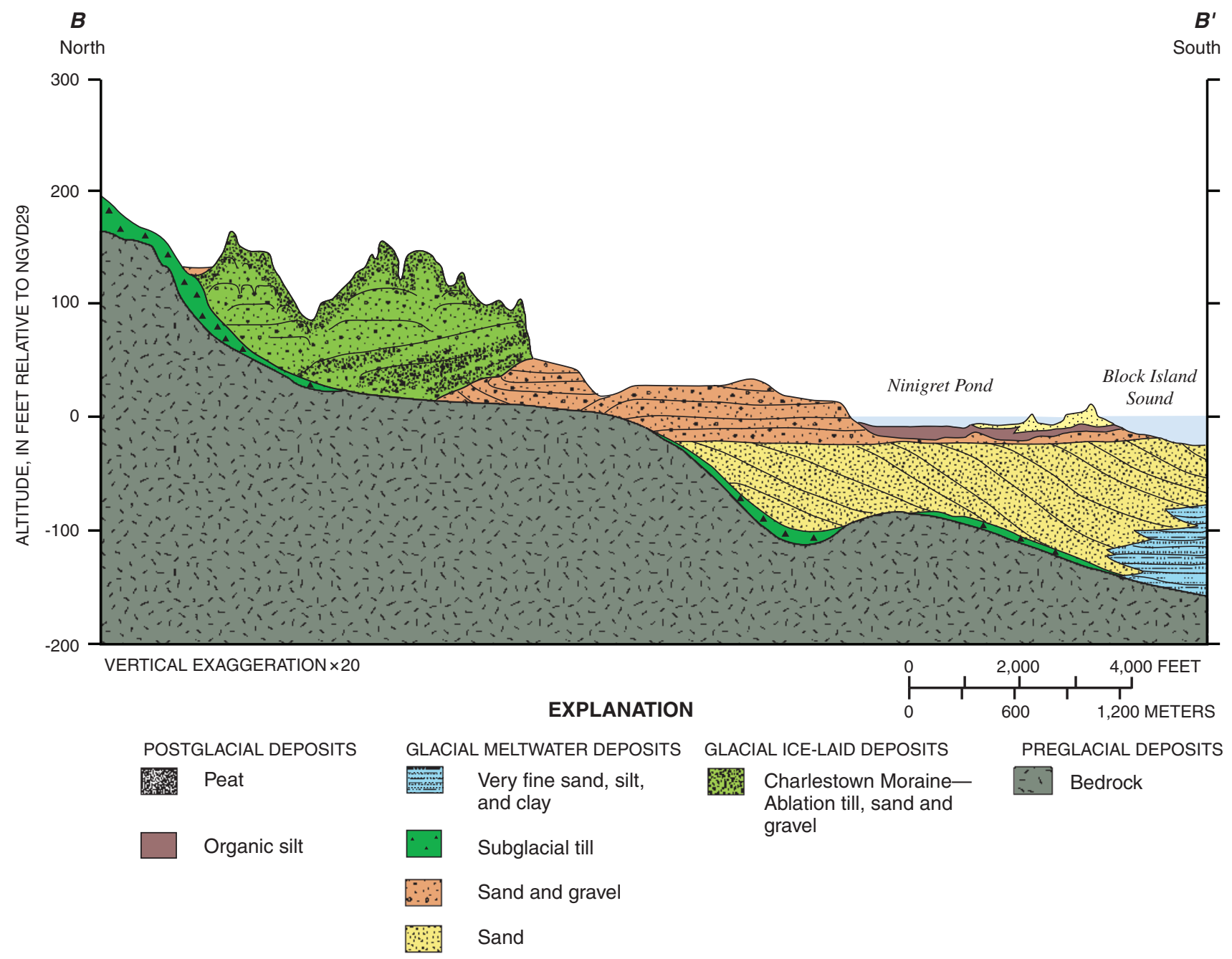

Figure 4. Geologic cross sections $(A$ and $B)$ showing deposits of southern Rhode Island. The lines of the sections are shown on the map in figure 3. - Continued

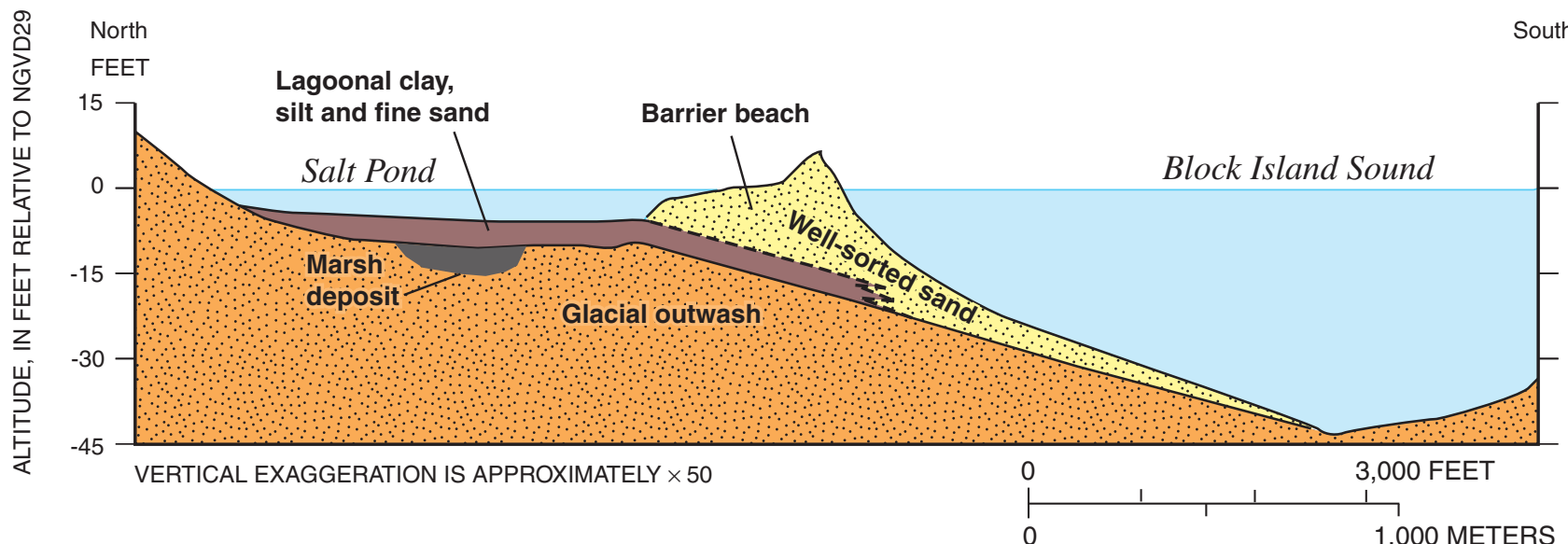

Figure 5. Generalized cross section of the Salt Pond region of southern Rhode Island. Modified from Dillon (1970). 


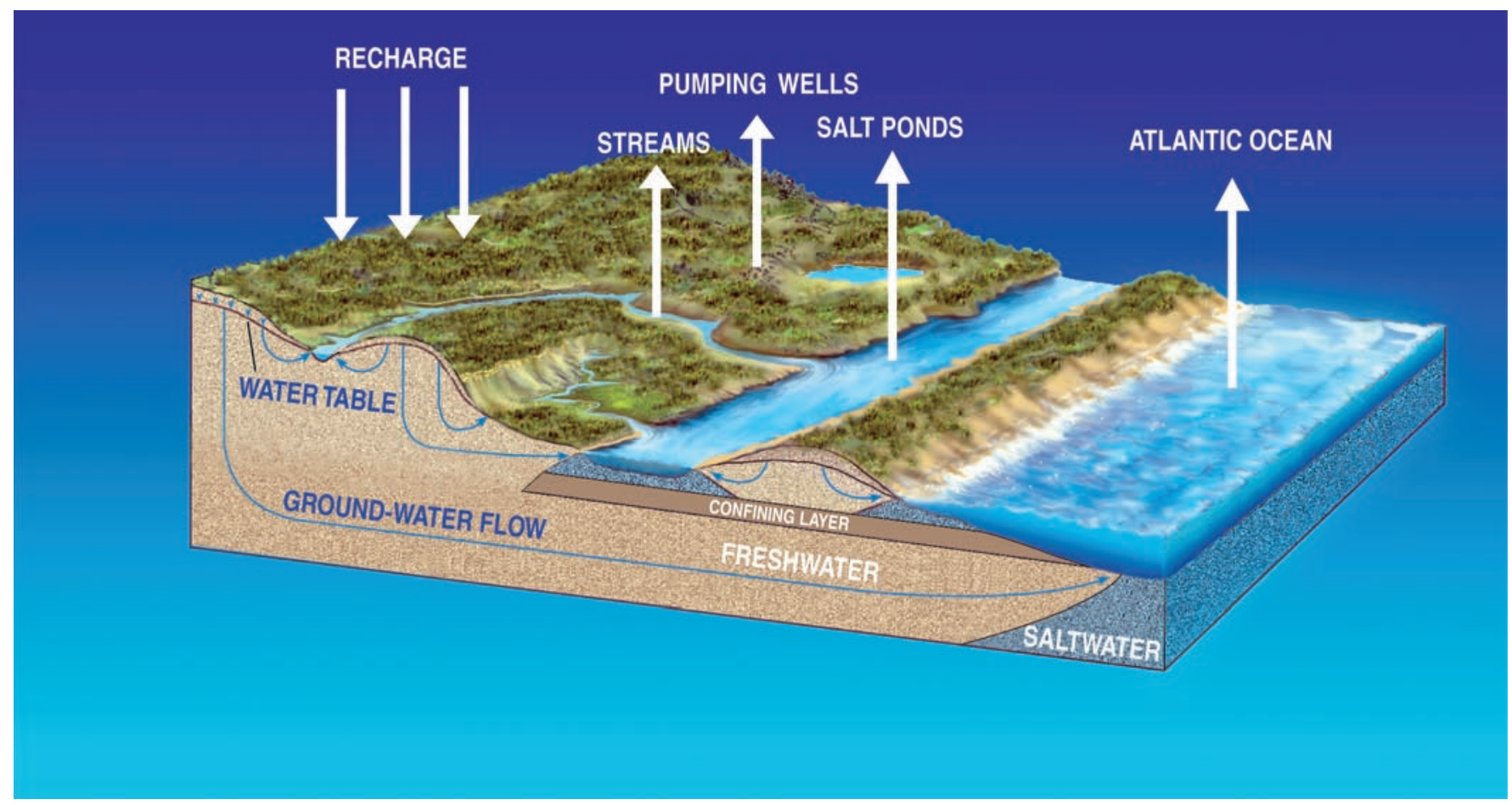

Figure 6. Diagram of ground-water flow in the South Coastal Basin aquifer, southern Rhode Island. Freshwater enters the aquifer as recharge from precipitation and leaves as ground water pumped from wells, discharged to streams, the salt ponds, or directly to the Atlantic Ocean. Modified from figure 3 in Barlow (2003).

National Oceanic and Atmospheric Administration (NOAA) station at T.F. Green Airport near Providence averaged about 45 in/year from 1960-2001 (National Oceanic and Atmospheric Administration, 2003). Recharge estimates from previous investigations in southern Rhode Island range from about 25 to 28 in/yr (Dickerman and others, 1997; Barlow and Dickerman, 2001; Friesz, 2004; Zarriello and Bent, 2004). Therefore, on average, about 38 to 44 percent of precipitation is lost through either evaporation or plant transpiration, and 25 to $28 \mathrm{in} / \mathrm{yr}$ enters the aquifer as recharge.

Recharge rates are assumed to be lower in wetlands (about $9 \mathrm{in} / \mathrm{yr}$ ) and ponds (14 in/yr) because of enhanced evapotranspiration in the surface-water bodies (Zarriello and Bent, 2004). Estimates of recharge in the upland till areas are also assumed to be lower than in the glacial stratified deposits because of enhanced runoff in these upland-till areas. Zarriello and Bent (2004) determined this recharge rate to be about $21 \mathrm{in} / \mathrm{yr}$ in till areas in southern Rhode Island, whereas Mullaney (2004) determined that recharge rates in similar till deposits in western Connecticut and eastern New York can be as low as $8 \mathrm{in} / \mathrm{yr}$.

It has been hypothesized that an additional source of freshwater may be ground water that potentially underflows the Pawcatuck River through deep north-south trending bedrock valleys that extend from the Pawcatuck River Basin to the coast (Ernst and others, 1999). No hydrologic data, however, are available to confirm the occurrence of this possible underflow beneath the Pawcatuck River.
Water that enters the aquifer as recharge flows from higher to lower water-level altitudes (fig. 6). Generally, in areas of high topographic relief, such as the upland till areas, the water-table contours tend to mimic the land-surface topography and ground water flows from these high areas to discharge areas, such as streams and inland wetlands, and ultimately to the coast. In the South Coastal Basin, the principal divide between surface-water flow to the Pawcatuck River to the north and to the coastline to the south is along the Charlestown Moraine (figs. 2 and 3). For watershed-management purposes, it has been assumed that the ground-water divide is coincident with the surface-water divide, which has served as the basis for the watershed delineations for the salt pond as discussed previously (Ernst and others, 1999; fig. 2); however, maps of water-table contours in the study area have shown that this is not always the case, especially near the Charlestown Moraine northeast of Ninigret Pond (Quonochontaug Quadrangle, LaSala and Johnson, 1960). In these areas, ground water flows from north to south from lower topographic altitudes north of the Charlestown Moraine, through the higher topographic altitudes of the Charlestown Moraine, to the lower topographic altitudes of the salt ponds.

Ground water is used in the study area for domestic, commercial, and industrial purposes. Detailed information regarding the use of this water is reported in Wild and Nimiroski (2004 a,b). Only the water pumped from large-capacity municipal wells is considered in this investigation. On-site 
domestic supply wells with on-site domestic septic systems were not considered in this investigation because the combination of on-site pumping and wastewater return flow has little effect on the regional ground-water system.

Public-supply water in the study area is obtained primarily from the production wells of the Westerly Water Department in Westerly and the Kingston, United Water of Rhode Island, and South Kingstown Water Departments in South Kingstown (fig. 1). The Narragansett Water Department obtains all of its water from United Water of Rhode Island. The average daily water volume pumped in the study area for public supply for 1995-99 as reported in Wild and Nimiroski (2004a,b) is about 7.2 Mgal/d.

Wastewater is either collected and treated at wastewatertreatment facilities or returned to the aquifer through on-site domestic septic systems. It is difficult to determine how much of the wastewater generated from the $7.2 \mathrm{Mgal} / \mathrm{d}$ pumped for domestic supply is exported to wastewater-treatment facilities (then discharged to surface-water bodies) or returned to the aquifer through on-site domestic septic systems, because although this information is available on a town-wide basis, town boundaries do not coincide with basin and study-area boundaries.

About $1.2 \mathrm{Mgal} / \mathrm{d}$ of water is returned to the aquifer after consumptive use (E.C. Wild, U.S. Geological Survey, written commun., 2005). This wastewater is returned to the aquifer through on-site domestic septic systems in the study area in the nonsewered areas within the water-supply districts shown on figure 1 . The remainder of the water pumped from the South Coastal Basin aquifer is either exported north of the Pawcatuck River for use outside the study area or used in sewered areas within the study area that discharge directly to the Pawcatuck River or Narragansett Bay through municipal wastewater-treatment facilities.

\section{Freshwater Flow Beneath Salt Ponds}

The coastal area is the ultimate discharge point for freshwater entering the South Coastal Basin aquifer as recharge from precipitation; however, where ground-water discharge occurs and how much water is discharging is not well understood and is the subject of ongoing research in the Salt Pond region (Rhode Island Sea Grant Program, 2001; Ernst and others, 1999; Kelly and Moran, 2002). Several possible groundwater discharge areas along the coast have been identified: (1) along the shoreline of the salt ponds; (2) beneath the salt ponds, seaward of the shoreline; or (3) beyond the barrierisland system directly into the Atlantic Ocean (fig. 6).

A geophysical technique known as continuous resistivity profiling (CRP) was used in this investigation to characterize the offshore extent of the ground-water discharge (submarine ground-water discharge) beneath the coastal waters and to better constrain the coastal discharge boundary used in the ground-water-flow model. A detailed discussion of this geophysical technique and the results of this effort are reported in appendix 1.

\section{Development of Ground-Water- Flow Model}

Numerical models provide a means to synthesize existing hydrogeologic information into an internally consistent mathematical representation of a real system or process and thus are useful tools for testing and improving conceptual models or hypotheses of ground-water-flow systems (Konikow and Reilly, 1999). A ground-water-flow model was developed for the South Coastal Basin aquifer for the purpose of (1) synthesizing the available hydrogeologic data, including a conceptual depositional model of the surficial glacial sediments of the region; (2) providing estimates of watershed delineations and ground-water fluxes to the salt ponds; and (3) assessing the effect of reasonable changes in simulated hydrogeologic parameters on these flux estimates.

The numerical model developed for simulating groundwater flow in the South Coastal Basin aquifer of southern Rhode Island was based on the USGS computer program MODFLOW (Harbaugh and McDonald, 1996). A USGS particle-tracking program (MODPATH) developed by Pollock (1994) was used to calculate the initial locations of water particles that discharge to the salt ponds and the streams that flow into them.

\section{Model Discretization and Boundaries}

The finite-difference model grid consists of a series of orthogonal model cells in which user-specified hydraulic parameters, model stresses, and boundary conditions are varied spatially. The conceptualization of how and where water enters, moves through, and leaves the aquifer is critical to the development of an accurate flow model (Reilly, 2001). A detailed discussion of grid discretization, boundary conditions, and the use of finite-difference equations to simulate groundwater flow is presented in McDonald and Harbaugh (1988).

\section{Spatial Discretization}

The total active modeled area of the South Coastal Basin aquifer is about $150 \mathrm{mi}^{2}$ (fig. 7). The finite-difference grid representing this area consists of 170 rows and 315 columns of uniformly spaced model cells that are $400 \mathrm{ft}$ on a side. The South Coastal Basin aquifer was subdivided vertically into five layers of variable thickness that extend from the water table to bedrock.

Previous modeling investigations in areas that include upland till and bedrock areas surrounding glacial stratified deposits typically do not explicitly simulate the upland areas, but rather specify the recharge that would have entered the aquifer through these areas as enhanced recharge at the till-glacial stratified deposits contact (Dickerman and others, 1997; Barlow and Dickerman, 2001; DeSimone and others, 2002; Granato and others, 2003; Friesz, 2004). This approach 


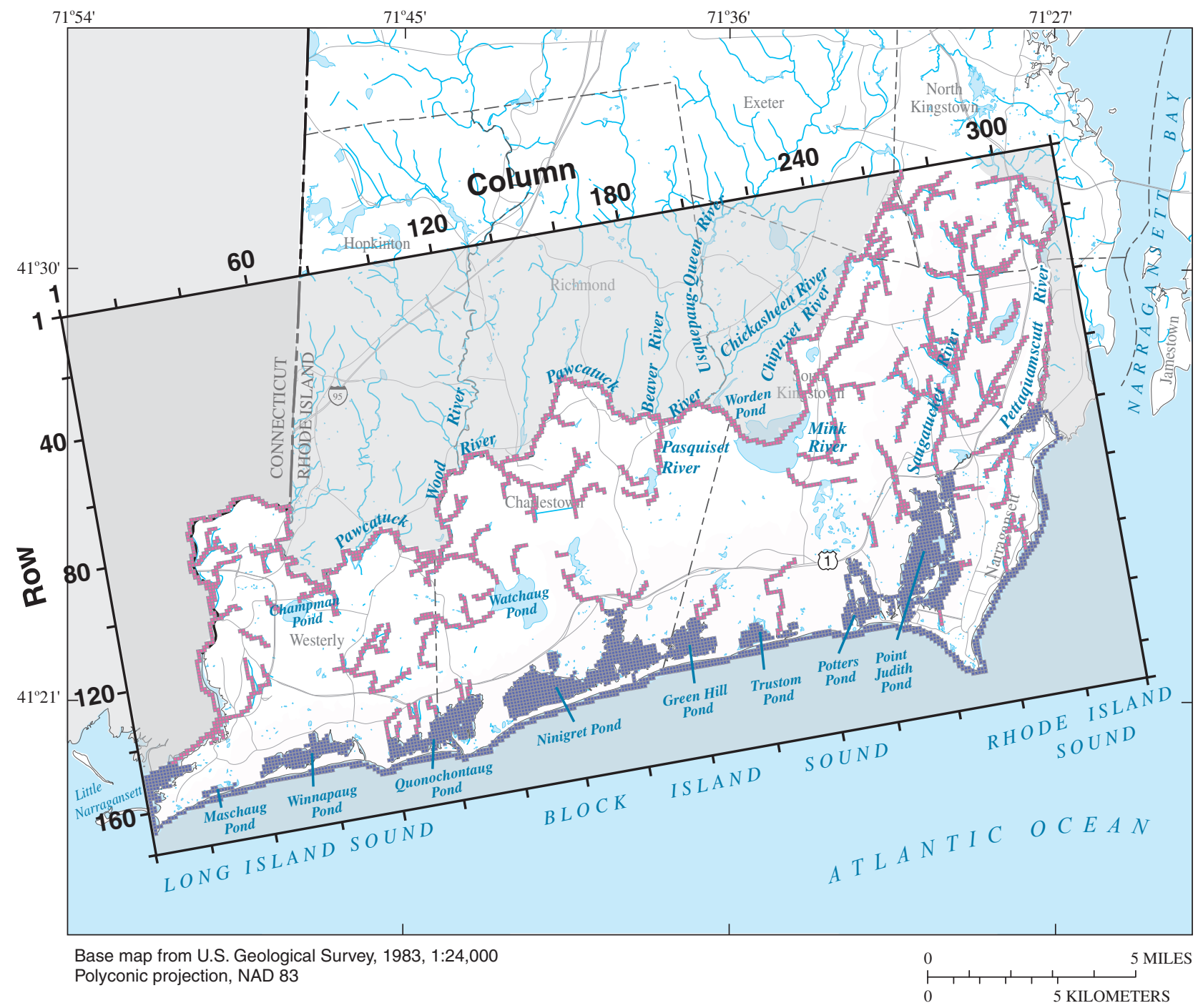

EXPLANATION

SIMULATED MODEL BOUNDARIES

CONSTANT HEAD

HEAD-DEPENDENT FLUX (DRN)

NO FLOW (INACTIVE)

Figure 7. Extent and distribution of boundary conditions for ground-water-flow model of South Coastal Basin aquifer, southern Rhode Island.

is used to avoid the numerical instabilities that result from simulating steeply sloping, thinly saturated deposits, such as the upland till areas north of the Charlestown Moraine.

A more recent investigation in the Assabet River Basin in central Massachusetts (DeSimone, 2004) used a fixed-transmissivity approach that allows for the simulation of both the glacial stratified deposits and the upland till and bedrock areas. This approach is equivalent to simulating a confined aquifer, which, for steady-state conditions where seasonal fluctuations of the water table are not represented, is a reasonable representation of the aquifer. The benefit of this approach is that it allows for simulation of the upland till and bedrock areas and a more realistic representation of flow from these upland areas to the surrounding glacial stratified deposits.

The model layer most affected by this fixed-transmissivity approach is the top layer. In the variable-transmissivity approach, the top of layer 1 is the water table calculated by the model, whereas in the fixed-transmissivity approach, the 


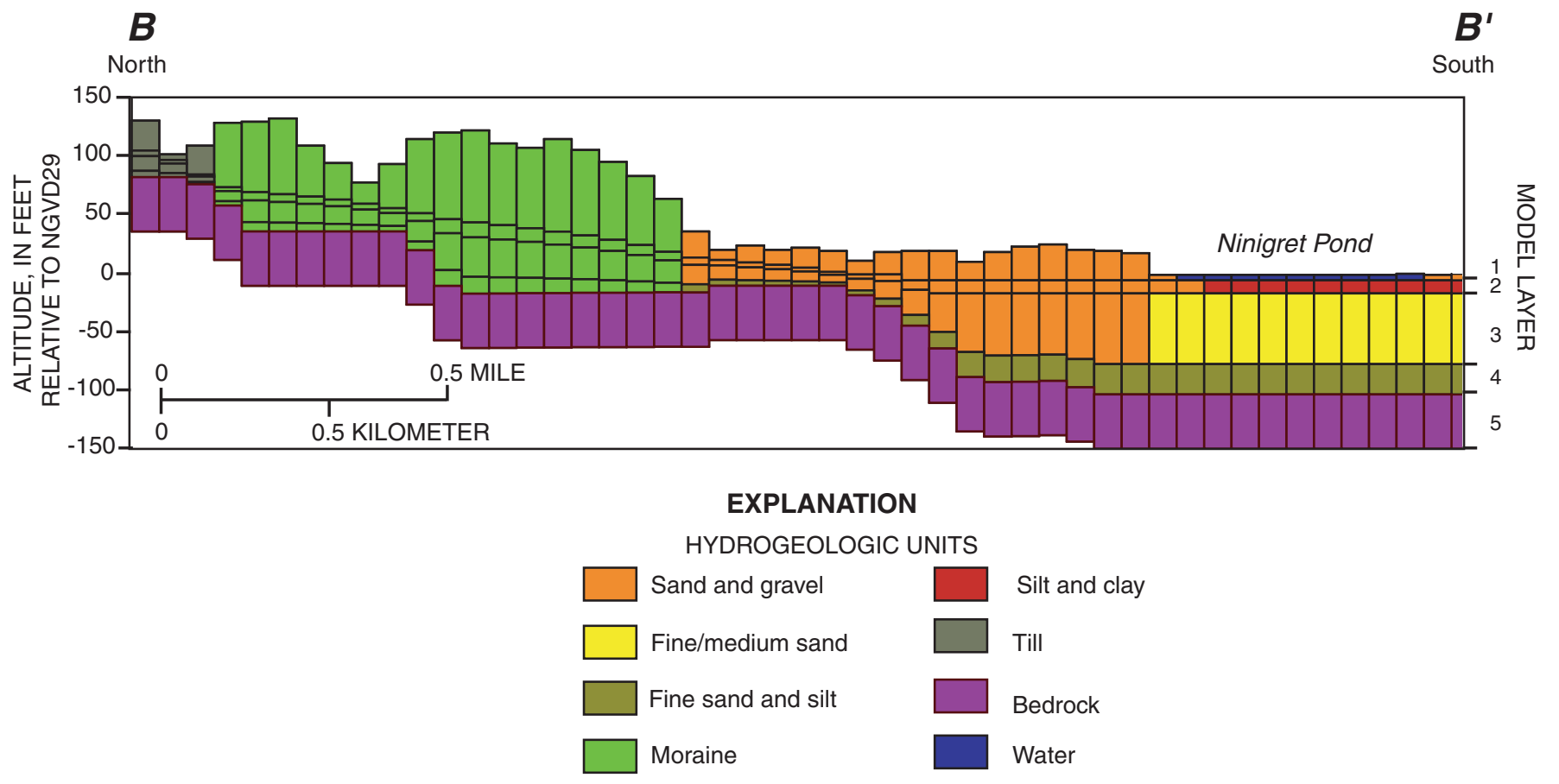

Figure 8. Model representation of geologic section $B-B^{\prime}$. Line of section is shown on figure 3 .

top of the layer must be specifed. The top of the uppermost layer (layer 1) was initially set to the land-surface elevation, which was interpolated from 30-m digital-elevation-model data (P.A. Steeves, U.S. Geological Survey, written commun., 2004), and then reset to the simulated water table during the model-calibration process. After several iterations of resetting the top of layer 1 based on the model-calculated water table, a reasonably close match to the observed water-level data was achieved, and that water-table altitude was then specified as the top of layer 1.

The glacial stratified deposits were then represented by four draping model layers (layers 1-4) from the water table to bedrock to allow for the detail necessary to represent the vertical changes in the lithology, the depth of the salt ponds, and the thickness of the pond-bottom sediments (sections $A-A^{\prime}$ and $B$ - $B^{\prime}$ ) (fig. 4). The bottom layer (layer 5) extends from top of bedrock to $50 \mathrm{ft}$ below the bedrock surface to allow for flow in bedrock in areas where unconsolidated deposits are thin, such as beneath upland tills. An example of the model layering in the area of section $B-B^{\prime}$ (fig. 3 ) is shown in figure 8.

\section{Hydrologic Boundaries}

The hydrologic boundaries, or boundary conditions, in the ground-water-flow model are the areas from which, and the method by which, all the water entering and leaving the model is specified. The boundaries of the numerical model of freshwater flow in the South Coastal Basin aquifer coincide with the physical boundaries of the flow system.

It was assumed in this investigation that the only input of freshwater to the modeled area is recharge from precipitation. It has been hypothesized that a potential additional source of freshwater may be ground water flowing beneath the Pawcatuck River through deep, north-south trending bedrock valleys that extend from the Pawcatuck River Basin to the coast (Ernst and others, 1999). No hydrologic data are available to confirm the existence of such underflow, but the ongoing modeling study in the Pawcatuck River Basin supports the hypothesis that the Pawcatuck River is the regional discharge location for southward-flowing ground water (G.C. Bent, U.S. Geological Survey, oral commun., 2004). 
The upper boundary of the model is the water table, which is a free-surface boundary that receives spatially variable recharge from precipitation and wastewater disposal. The lower boundary of the model is the crystalline bedrock that underlies the entire study area. The bottom of the model was set at $50 \mathrm{ft}$ below the bedrock surface to allow for simulation of the upper part of the bedrock. It was assumed that the upper $50 \mathrm{ft}$ of bedrock transmits water into and out of the South Coastal Basin aquifer, especially beneath the upland areas where thin (less than $20 \mathrm{ft}$ ) till deposits overlie weathered bedrock.

The lateral boundaries of the model, through which all discharge to streams and the coast occurs, are represented in the model as either head-dependent flux boundaries or specified-head boundaries. The head-dependent flux boundary used to represent streams in the model specifies stream stage and streambed conductance. The specified stream stage represents the surface-water level of the stream, and the streambed conductance represents the hydraulic connection between the stream and the ground-water system.

These stream boundaries were simulated by the Drain Package (DRN) in MODFLOW (McDonald and Harbaugh, 1988), which assumes the stream can only receive water from the aquifer. Therefore, it is assumed that all the streams in the South Coastal Basin aquifer only receive ground-water discharge and that no water flows from the streams to the aquifer.

Discharge fluxes to the streams are calculated by the model on the basis of the hydraulic gradient between the model-calculated head in the model cell and the specified boundary head and hydraulic conductance at the boundary face. The boundary head specifed for the streams simulated in the DRN package was determined by the stream-stage altitudes estimated from the digital elevation data for the study area (P.A. Steeves, written commun., 2004). The hydraulic conductance was calculated for each model cell containing a stream, as described in McDonald and Harbaugh (1988), as

$$
C=\frac{(K)(W)(L)}{(M)},
$$

where

$C$ is hydraulic conductance of the streambed, in square feet per day;

$K$ is vertical hydraulic conductivity of streambed deposits, in feet per day;

$W$ is the width of the stream, in feet;

$L$ is the length of the stream within model cell, in feet; and

$M$ is the thickness of the streambed, in feet.

The parameters used to calculate hydraulic conductance (C) were assumed to be the same for all streams and rivers in the study area. The simulated vertical hydraulic conductivity of the streambed deposits $(K)$ was $40 \mathrm{ft} / \mathrm{d}$; it was assumed that the permeability of the streambed is similar to that of the surrounding aquifer. The width $(W)$ of the streams was assumed to be $10 \mathrm{ft}$, the length $(L)$ was equal to the length of the model cell containing the stream (400 ft), and the thickness
$(M)$ was assumed to be $5 \mathrm{ft}$. Adjustments to these parameters may affect the location and amount of model-calculated fluxes from these simulated surface-water bodies; therefore, localscale analyses of specific surface-water bodies may require more detailed hydrologic data collection than was possible for this regional analysis.

Specified, or constant-head, boundaries are used for large surface-water bodies, such as the salt ponds and the Atlantic Ocean. It is assumed that flow to or from these water bodies will not affect their water levels. The amount of water flowing between the surface-water body and the aquifer in the model depends on the ground-water heads in the model cells that surround the specified-head boundary (Reilly, 2001).

The constant head specified for the Atlantic Ocean was $0.6 \mathrm{ft}$ above NGVD 29, which is consistent with a long-term tidal gage in Narragansett Bay, Newport, R.I. (Ernst and others, 1999). The water-level altitude of the individual salt ponds could not be obtained; however, it was assumed that pond levels were higher than the Altantic Ocean, but lower than the water-level altitudes of the observation wells close to the coast. A uniform value of $1.5 \mathrm{ft}$ above NGVD 29 was specified in all the ponds. Model simulations showed that adjusting this value $+/-1.0 \mathrm{ft}$ had little effect on model-calculated fluxes to these coastal waters.

\section{Hydrologic Stresses}

The hydrologic stresses simulated in the model include recharge from precipitation and return flow from domestic waste disposal, and pumping for municipal water supply. The recharge estimates are based on previous investigations and represent long-term average conditions. The pumping from municipal supply and the resulting wastewater return flow estimates are based on the average daily pumping rates from 1995 through 1999 (Wild and Nimiroski, 2004a,b).

\section{Recharge}

The only natural inflow of freshwater to the South Coastal Basin aquifer is recharge from precipitation. Specified recharge rates ranged from 9 to $27 \mathrm{in} / \mathrm{yr}$ throughout the modeled area depending on the surficial geology and the presence of ponds, streams, and wetlands. Areas defined on the surficial-materials map (fig. 3) as glacial stratified deposits, excluding wetlands, had a specified recharge rate of $27 \mathrm{in} / \mathrm{yr}$, based on previous investigations in southern Rhode Island (Dickerman and others, 1997; Barlow and Dickerman, 2001; Granato and others, 2003; Friesz, 2004; Zarriello and Bent, 2004).

In areas characterized as till deposits (fig. 3), the recharge rate was reduced from 27 to $21 \mathrm{in} / \mathrm{yr}$ because it was assumed that surface runoff in these upland areas can account for as much as a $6 \mathrm{in} / \mathrm{yr}$ reduction in recharge (DeSimone, 2004; Zarriello and Bent, 2004). It is then assumed this surface runoff discharges to wetlands that border these upland areas, and this 
Table 1. Average pumping rates for production wells in the South Coastal Basin aquifer, southern Rhode Island, 1995-99.

[Map code: Location shown on figure 1. UWRI, United Water of Rhode Island. Pumping rates are in million gallons per day]

\begin{tabular}{|c|c|c|c|c|c|}
\hline \multirow{2}{*}{ Well name } & \multirow{2}{*}{$\begin{array}{l}\text { Map } \\
\text { code }\end{array}$} & \multirow{2}{*}{$\begin{array}{c}\text { Pumping } \\
\text { rate } \\
(1995-99)\end{array}$} & \multicolumn{3}{|c|}{ Model cell } \\
\hline & & & Layer & Row & Column \\
\hline Crandall & 1 & 0.327 & 3 & 117 & 55 \\
\hline Bradford II & 2 & .270 & 4 & 96 & 84 \\
\hline Bradford III & 3 & .281 & 4 & 103 & 78 \\
\hline South Kingstown No. 1 & 4 & .195 & 3 & 120 & 188 \\
\hline South Kingstown No. 2 & 5 & .195 & 3 & 119 & 190 \\
\hline UWRI No. 1 & 6 & .012 & 3 & 86 & 240 \\
\hline UWRI No. 2 & 7 & .297 & 3 & 86 & 239 \\
\hline UWRI No. 3 & 7 & .010 & 3 & 86 & 239 \\
\hline UWRI No. 4 & 6 & .398 & 3 & 86 & 240 \\
\hline UWRI No. 5 & 8 & .839 & 3 & 86 & 227 \\
\hline UWRI No. 6 & 9 & 1.047 & 3 & 86 & 228 \\
\hline Total pumping & & 3.871 & & & \\
\hline
\end{tabular}

water is lost to enhanced evapotranspiration or surface-water drainage in these wetlands (Zarriello and Bent, 2004).

Recharge rates also were reduced in areas occupied by ponds and wetlands. It was assumed the recharge rate for ponds was equal to $17 \mathrm{in} / \mathrm{yr}$, which is the annual average precipitation rate of $45 \mathrm{in} / \mathrm{yr}$ minus the annual average free-watersurface potential evaporation rate of $28 \mathrm{in} / \mathrm{yr}$ from surfacewater bodies for northeastern United States (Farnsworth and others, 1982).

In wetlands, evapotranspiration is assumed to account for a substantial loss of water, which can be as large, or larger, than the evaporation loss from ponds because of the combined effect of evaporation and transpiration in these flooded, vegetated areas. Therefore, a uniform recharge rate of $9 \mathrm{in} / \mathrm{yr}$ was specified for all the wetlands in the study area, which is about half the recharge rate specified for ponds and is one third the rate for the surrounding aquifer. This value was based on a previous analysis in the Pawcatuck River Basin (Zarriello and Bent, 2004). It should be noted, however, that recharge in wetlands can vary greatly depending on the extent of open water, amount and type of vegetation, location of the wetland in the flow system, and whether the wetlands have surfacewater outflows (P.J. Zarriello, U.S. Geological Survey, written commun., 2005).

Recharge in wetlands is poorly characterized and subject to a large degree of uncertainty as noted by the previously mentioned complexities. As a result, recharge rates for wetlands simulated in numerical models commonly are determined through model calibration rather than by field measurements. The areas occupied by inland wetlands in the South Coastal Basin aquifer account for only about 9 percent of the total surface area and most of these wetlands are north of the ground-water divide that separates the flow to the Pawcatuck River from flow to the coastal areas. Therefore, large changes in the recharge rates specified for wetlands in the study area have little effect on the amount of ground-water discharge to the coastal areas.

An additional input of water simulated in the flow model is the return of wastewater from on-site domestic waste disposal via septic systems. This additional source of water was 1.2 Mgal/d, or about 1 percent of the total recharge simulated in the model. This wastewater recharge was specified in the model in the cells that included residential areas in the nonsewered parts of the water-supply districts shown on figure 1 .

\section{Pumping}

Pumping for municipal supply was simulated in the model from 11 production wells in the towns of Westerly, South Kingstown, and North Kingstown (fig. 1). The total pumping simulated was about $3.9 \mathrm{Mgal} / \mathrm{d}$ (table 1 ). The total pumping from the study area is about $7.2 \mathrm{Mgal} / \mathrm{d}$; however, about $3.3 \mathrm{Mgal} / \mathrm{d}\left(5.1 \mathrm{ft}^{3} / \mathrm{s}\right)$ of this pumping is from wells along the Pawcatuck River, which are not simulated in the model. It was assumed that because the Pawcatuck River has an average daily flow of $576 \mathrm{ft}^{3} / \mathrm{s}$ at the Westerly, R.I., streamflow-gaging station (station identifier 01118500, fig. 1) (Socolow and others, 2004), the small amount of pumping $\left(5.1 \mathrm{ft}^{3} / \mathrm{s}\right)$ from the area near the river would have no effect on either the river or ground-water flow to the salt ponds.

\section{Hydraulic Properties}

The hydraulic properties required as input data for the steady-state simulation of ground-water flow for this investigation are the horizontal and vertical hydraulic conductivity of the aquifer. The hydraulic-conductivity values initially specified in the flow model were assigned on the basis of aquifer test, lithologic, and geologic information (Gonthier and others, 1974, Melvin and others, 1992), as well as values used in previous modeling investigations in southern Rhode Island (Dickerman and others, 1990; Dickerman and others, 1997; Barlow and Dickerman, 2001; Granato and others, 2003; Friesz, 2004). Hydraulic-conductivity values were distributed on the basis of the geologic processes that formed the glacial deposits of the South Coastal Basin aquifer. The relation between geologic framework and hydraulic-conductivity values from a similar hydrogeologic setting on Cape Cod was used for this analysis in southern Rhode Island (Masterson and others, 1997; Masterson, 2004; Walter and Whelan, 2004).

The range of horzontal hydraulic-conductivity values specified in the flow model is listed in table 2 for the lithologic deposits shown in the surficial-materials map (fig. 3) and in sections $A-A^{\prime}$ and $B-B^{\prime}$ (fig. 4). An example of the distribution of hydraulic-conductivity values simulated in the calibrated model is shown for cross-section $B-B^{\prime}$ (fig. 8) to illustrate the relation between the model simulated hydraulic-conductiv- 
Table 2. Lithology and hydraulic conductivity of lithologic units used in the ground-water-flow model of the South Coastal Basin aquifer, southern Rhode Island.

[ft/d, foot per day]

\begin{tabular}{lrr}
\hline \multicolumn{1}{c}{ Lithologic deposit } & $\begin{array}{c}\text { Horizontal hydraulic } \\
\text { conductivity } \\
\text { (ft/d) }\end{array}$ & Anisotropy \\
\hline Stratified glacial deposits & & \\
$\quad$ Sand and gravel & $350-200$ & $3: 1-5: 1$ \\
Fine/medium sand & $125-70$ & $10: 1-30: 1$ \\
$\quad$ Fine sand and silt & $30-10$ & $30: 1-100: 1$ \\
$\quad$ Silt and clay & $10-.01$ & $100: 1-1: 1$ \\
Morainal deposits & $70-10$ & $30: 1-100: 1$ \\
Peat $\quad 1$ & $100: 1$ \\
Till $\quad 5-1$ & $10: 1$ \\
Bedrock & 1 & $10: 1$ \\
\hline
\end{tabular}

ity values and the lithologic section from which they were derived. The final values simulated in the model were obtained from minor adjustments during the model-calibration process within the ranges listed in table 2.

Surface-water bodies, such as ponds and wetlands, were simulated as part of the aquifer system. It was assumed that kettle-hole ponds are in direct hydraulic connection with the aquifer, and therefore, represent parts of the aquifer that have no effective resistance to flow. As a result, ground-water flow lines converge towards ponds in upgradient areas, where ground water discharges to ponds, and diverge in downgradient areas, where ponds lose water to the aquifer. Ponds are simulated in the model as areas of high hydraulic conductivity $(50,000 \mathrm{ft} / \mathrm{d})$, as much as two orders of magnitude higher than the values specified for the surrounding aquifer (table 2).

It was assumed that wetlands had a greater resistance to horizontal flow than the kettle-hole ponds, yet less resistance to flow than the surrounding aquifer. As a result, areas of wetlands were assigned horizontal hydraulic-conductivity values ranging from 1,000 to $10,000 \mathrm{ft} / \mathrm{d}$, depending on the extent of open water within them.

The peat deposits that underlie the wetlands were assigned a horizontal hydraulic-conductivity value of $1 \mathrm{ft} / \mathrm{d}$ to account for the highly decomposed peat and organic-rich silts present beneath the wetlands (Friesz, 2004). It was assumed the peat deposits are highly anisotropic, and as a result, the vertical hydraulic conductivity of these deposits was specified at $0.01 \mathrm{ft} / \mathrm{d}$ (anisotropy of 100:1) (table 2).

The streambed deposits were assumed to be much more permeable than the wetland peats and more like the surrounding aquifer. Therefore, the vertical-hydraulic conductivity value used to determine the conductance, discussed previously in the section "Hydrologic Boundaries," is $40 \mathrm{ft} / \mathrm{d}$, the verticalhydraulic conductivity associated with a horizontal hydraulic conductivity of $200 \mathrm{ft} / \mathrm{d}$.
The geologic framework of the salt ponds, discussed in the section "Geologic Setting," indicates that the ponds are generally underlain by low-permeability organic material, silts, and clay (fig. 5). Field observations of the pond-bottom sediments along the shoreline indicate that the sediments may be more permeable and similar to the sand and gravels that underlie the less permeable pond-bottom deposits away from the shoreline. The pond-bottom deposits were represented numerically in the model by specifying horizontal and vertical-hydraulic conductivity values of $0.01 \mathrm{ft} / \mathrm{d}$ throughout the salt ponds in layer 2. Along the first model cell seaward of the shoreline, a zone of higher hydraulic-conductivity values was specified similar to the value used for the glacial stratified deposits that underlie the low-permeability pond-bottom deposits. The hydraulic-conductivity value specified along the shoreline was $200 \mathrm{ft} / \mathrm{d}$ in the horizontal and $40 \mathrm{ft} / \mathrm{d}$ in the vertical (table 2). The geologic framework of the ponds was assumed to be similar throughout the study area and, therefore, all the ponds were represented in the same manner. For more local pond-scale investigations, a more detailed characterization of the pond bottom would be required, and the representation of the pond-bottom subsurface lithology would need to be revised accordingly.

\section{Model Calibration}

Model calibration is the process by which modifications are made to the initial model-input parameters for the purpose of making the model output more closely match observed water levels and streamflows (Reilly and Harbaugh, 2004). Ideally, water-level and streamflow measurements used for model calibration are made over a relatively short period (within several days) and represent long-term average conditions. Because no new hydrologic data were collected for this investigation, the data used for model calibration was limited to that collected during previous investigations, data not necessarily ideal for model calibration. Because of the limitations in existing water-level and streamflow data, there was little justification to support substantial changes to the initially specified hydraulic parameters in order to improve the match between the model-calculated and measured hydrologic data. Also, it is important to note that ground-water-flow models produce non-unique solutions, such that the same model-calculated response in water levels or streamflows might be obtained by using different combinations of hydraulic parameters.

An example of a non-unique solution would be the combination of a lower recharge rate and lower hydraulicconductivity values in one simulation resulting in the same model-calculated distribution of water-levels and streamflows in a second simulation in which a combination of a higher recharge rate and higher hydraulic-conductivity values was used. Both of these simulations may produce an acceptable match to the measured values; however, the total flow 
through the model, and ultimately the total discharge to the coast, would differ directly by the difference in the recharge rate specified in the simulations. Without knowing with some degree of certainty the actual recharge rate or distribution of hydraulic conductivity in the study area, it would be difficult to determine which simulation provides the better representation of the actual ground-water-flow system.

An additional source of information that may improve model calibration is the use of geochemical tracers, such as naturally occurring radionuclides, to estimate ground-water fluxes to coastal waters (Kelly and Moran, 2002). This technique provides an innovative means of estimating groundwater discharge to large surface-water bodies. Although this geochemical method is subject to many assumptions and conditions, it provides some means of quantifying ground-water discharge to coastal waters that otherwise would be impossible to measure directly. Quantifying the amount of groundwater discharge to coastal waters, in addition to measuring streamflows and water levels, would further constrain the ground-water-flow model to provide a reasonable representation of the actual ground-water-flow system.

For the purpose of this investigation, only the hydraulicconductivity values were adjusted during the model-calibration process. It was assumed that the recharge rate estimated as part of a previous investigation in the Pawcatuck River Basin (Zarriello and Bent, 2004) was reasonable; therefore, it was not adjusted as part of the calibration process here. As part of the uncertainty analysis described in the section "Factors that Affect Simulated Flow to the Salt Ponds," however, the recharge rate was adjusted to evaluate the effect of changes in recharge on the total flow to the salt ponds.

Given the limited accuracy of the model-calibration data, only minor adjustments were made to the initially specified hydraulic-conductivity values to provide a reasonable match to the available field data and yet remain consistent with the published hydraulic-conductivity values for similar hydrogeologic settings in southern New England (Masterson and others, 1997) (table 2). These adjustments were not made to match individual calibration targets, such as observed water levels and streamflows, but rather to resolve regional inconsistences between the field data and the model. Adjustments then were made to the final values specified in the calibrated model to assess the effect of these changes on the modelcalculated fluxes to the salt ponds. This analysis is described in the section "Simulation of Changes in Selected Hydraulic Properties."

Finally, given the large extent of the modeled area and the scope of this investigation, it was impractical to collect enough hydrogeologic data to fully characterize the hydraulic parameters needed as model input and the hydrologic data needed for model calibration. However, a numerical model developed according to a well-reasoned conceptual model of the aquifer system and an understanding of the uncertainty and limitations of the simulation results can provide a valuable tool for improving the understanding of ground-water flow and discharge to the salt ponds.

\section{Water-Level Data}

The water-level data available for model calibration were primarily from the USGS Ground-Water Map (GWM) series and USGS Geological Bulletin (GB) series (GWM-5, Hahn, 1959; GWM-9, LaSala and Hahn, 1960; GWM-11, LaSala and Johnson, 1960; GWM-14, Johnson, 1961a; GWM-16, Johnson, 1961b; and GB-9, Bierschenk, 1956). These map reports correspond to the seven USGS topographic quadrangles that constitute the study area. The water-level altitudes shown on these maps include measurements made between 1954 and 1961, depending on when the quadrangle water-table-map investigations were completed. As a result, observation wells in some parts of the study area were measured as early as July 1954 and other wells were measured as late as June 1961.

In addition to the water-level measurements made between 1954 and 1961, the USGS has maintained a longterm observation well (CHW-18) in Charlestown, R.I. (fig. 1), from 1946 to the present (2007). The change in monthly water levels measured at this well for the period 1954-61 and the median water-level measurement for the period 1946-2004 are plotted on the hydrograph shown in figure 9. This hydrograph shows that water levels measured monthly at this well varied by as much as $5 \mathrm{ft}$ from the median water-level measurement for the period 1946-2004.

The annual fluctuations in water levels measured at the wells from 1954 through 1961 for the quadrangle water-table maps may have been greater or less than the 5-ft fluctuation observed at well CHW-18 for that period, depending on the locations of the wells within the aquifer. The closer the well is to the coast, the lower was the magnitude of the water-level fluctuations at the well. The large fluctuation in water levels at well CHW-18 suggests that single water-level measurements made in the South Coastal Basin aquifer for the quadrangle water-table maps during times when the water level at observation well $\mathrm{CHW}-18$ was not at the long-term median value do not necessarily represent long-term average conditions in the aquifer. Furthermore, the measuring-point altitudes of these wells were determined from map-estimated altitudes on the USGS 1:24,000 topographic maps for the study area. Errors in measuring-point altitude can be substantial (more than $5 \mathrm{ft}$ ) in areas of high topographic relief, such as in the upland tills and the Charlestown Moraine, and as much as $3 \mathrm{ft}$ in areas of low relief, such as in the glacial stratified deposits south of the moraine (fig. 3). Because of the potentially large errors associated with the measuring-point altitudes of the wells in areas of high topographic relief, water levels in the wells in these areas were not used for model calibration. Instead, only the water levels in wells in the glacial stratified deposits were used for the comparison between modeled and measured water levels (fig. 10).

Given the uncertainty of the measuring-point altitudes of these wells and the fact that the model layering is finely discretized vertically in the upper part of the aquifer, it was assumed, for the purpose of comparing model-calculated and measured water levels, that all the wells are completed 


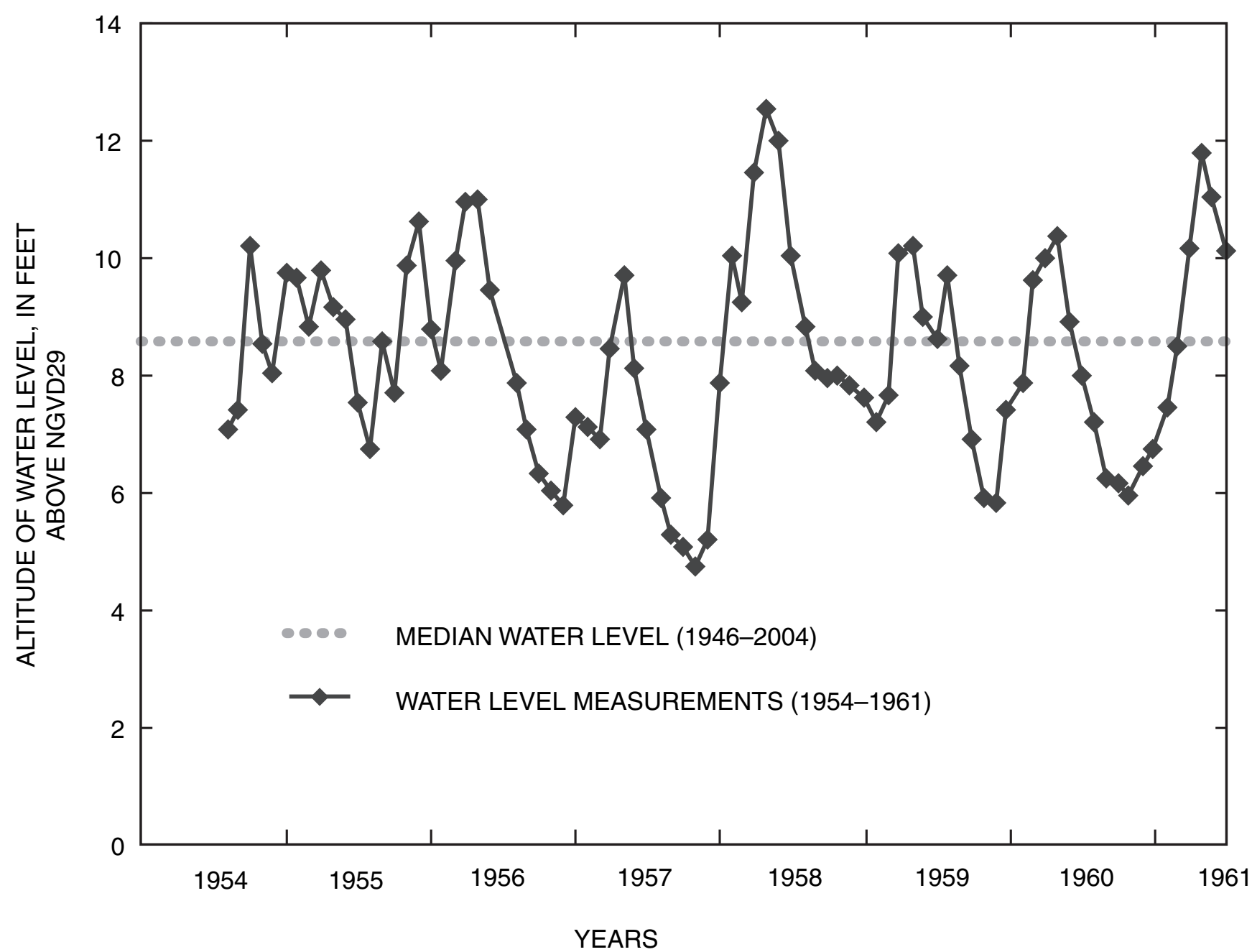

Figure 9. Long-term water levels for U.S. Geological Survey observation well Charlestown 18 (CHW-18), southern Rhode Island, from 1954 through 1961. Median water level for period 1946-2004 shown as dashed line.

in the top layer of the model. Simulation results indicate little vertical change in water levels between layers 1 and 3; therefore, the assumption that all of the wells are completed in layer 1 does not affect the comparison between measured and model-calculated water levels. The locations of these wells are shown in figure 10, and the comparison between these measured values and the modeled water levels are reported in table 3 (at the end of the report).

Model calibration to water levels includes a determination of the mean of the residuals (the difference between measured and model-calculated water levels) and the absolute mean of the residuals. Ideally, the mean of the residuals will be randomly distributed and close to zero, indicating no bias in the results and the mean of the absolute residuals is less than 5 percent of the total range in head for the water-level measurements used for model calibration (Anderson and Woessner, 1992). For the 142 wells used for model calibration, the mean of the residuals was $-0.36 \mathrm{ft}$ and the mean of the absolute errors was $3.97 \mathrm{ft}$, less than 3 percent of the total range $(155 \mathrm{ft})$ in water levels.
These wells were then subdivided by their location relative to the topographic divide, thus separating the wells in the glacial stratified deposits in the lower part of the Pawcatuck River Basin, north of the topographic divide, from the South Coastal Basin. The calibration statistics were determined separately for the wells in the South Coastal Basin and the Pawcatuck River Basin. The mean of the water-level residuals in the 61 wells in the South Coastal Basin is $-0.03 \mathrm{ft}$, the mean of the absolute residuals is $1.72 \mathrm{ft}$, and the percentage error over the total water-level range of $34 \mathrm{ft}$ is about 5 percent (table 3 ). The mean of the water-level residuals in the 81 wells in the part of the Pawcatuck River Basin included in the study area is -0.60 $\mathrm{ft}$, the absolute mean of the water-level residuals is $5.66 \mathrm{ft}$, and the percentage error over the total water-level range of $155 \mathrm{ft}$ is about 4 percent (table 3 ).

The model-calculated water levels in ponds were also compared to the pond levels shown on the USGS 1:24,000 topographic maps for the study area. Fourteen ponds in the study area were used for this comparison (fig. 10, table 4). Unlike the wells, the ponds were not limited to those only 

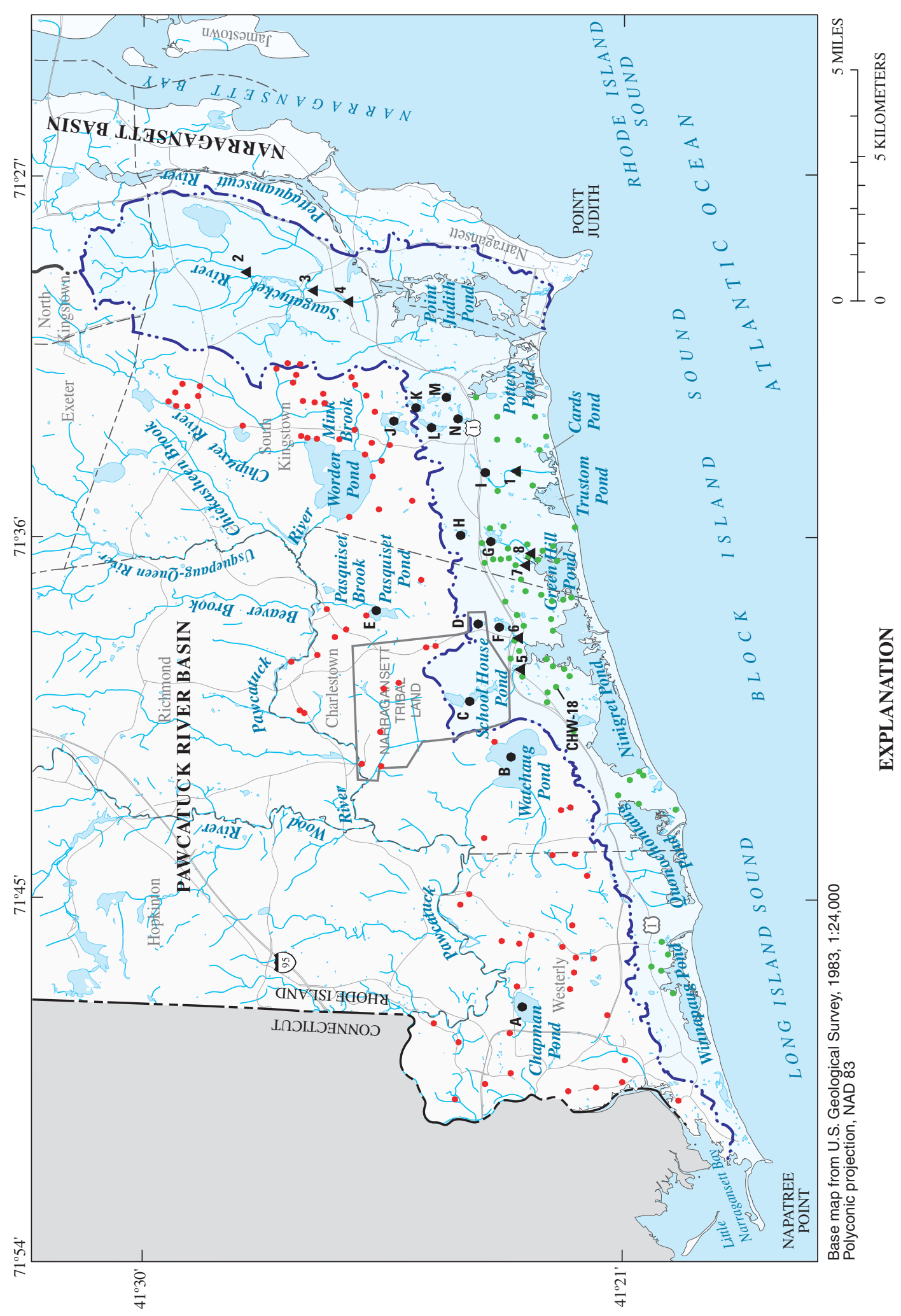

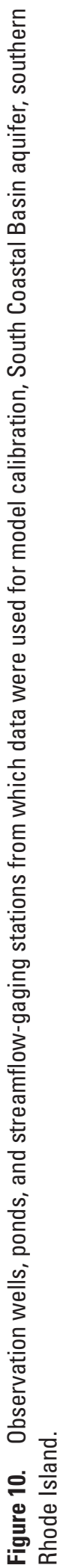


Table 4. Water levels for selected ponds in the modeled area determined by plane-table surveys between 1953 and 1957 and reported on U.S. Geological Survey 1: 24,000 topographic maps, and the model-calculated water levels for simulated current (1995-99) pumping and recharge conditions, South Coastal Basin aquifer, southern Rhode Island.

[Map code: Shown on figure 10. Residual: Residual equals map-estimated minus model-calculated. All values in feet relative to NGVD 29]

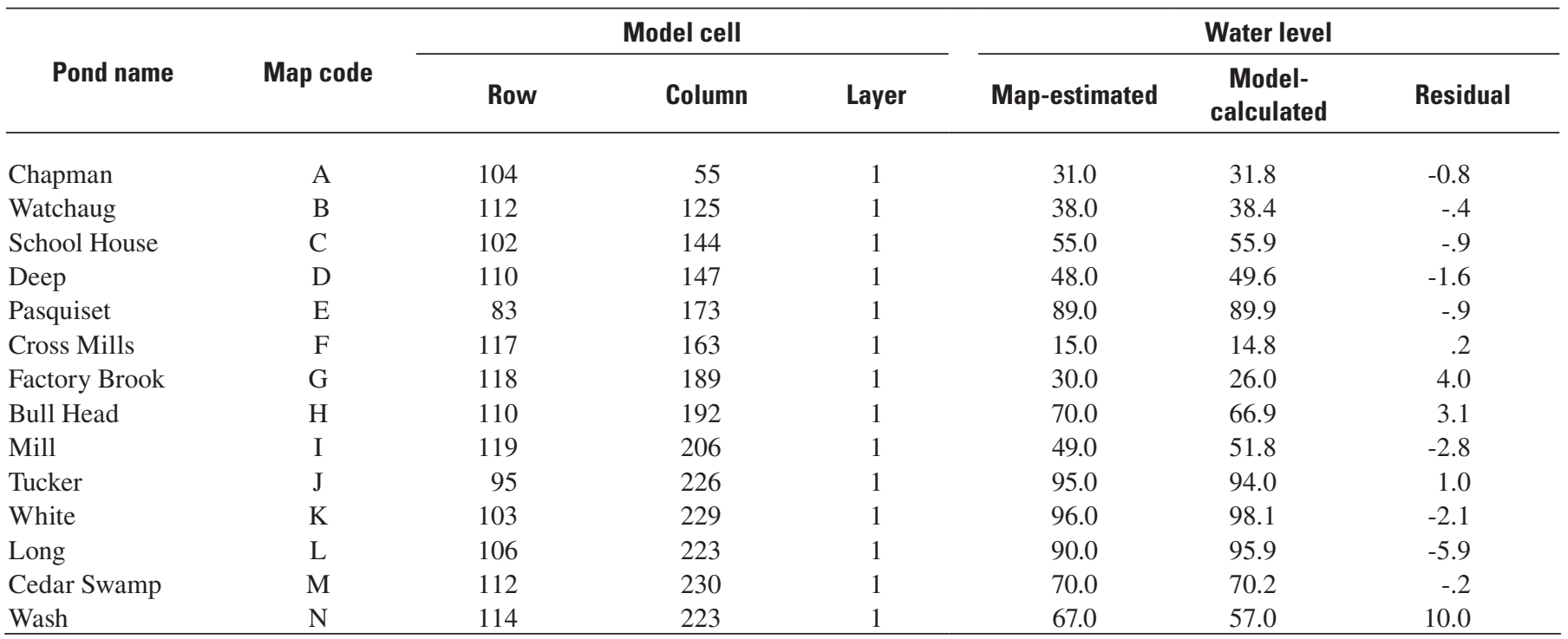

located in the glacial stratified deposits, because the error associated with the map-estimated measuring-point altitudes of the wells is not a concern with the pond altitudes. The pond altitudes indicated on the topographic maps were determined by plane-table surveys conducted over a four-year period from 1953-1957. This time period coincides with the period in which water levels in the observation wells were measured in the study area. The mean of the water-level residuals in the 14 ponds in the study area is $0.17 \mathrm{ft}$, the mean of the absolute water-level residuals is $2.37 \mathrm{ft}$, and the percentage error over the total water-level range of $81 \mathrm{ft}$ in the ponds is about 3 percent (table 4).

The current pumping rates (average for 1995-99, table 1) of wells were simulated during model calibration even though these wells were not being pumped or were being pumped at much lower rates when the water levels in observation wells used for calibration were measured. The few areas possibly affected by these pumping wells did not have a substantial effect on the model calibration. The area most likely affected by pumping from the South Coastal Basin aquifer is that around Factory Brook Pond (fig. 1). When the pumping from production wells in this area was removed, the simulated altitude of Factory Brook Pond increased by about $1.4 \mathrm{ft}$; however, given the limitations of the water-level data in the area around the pumping wells, this difference was still within a reasonable match of the calibration data.

\section{Streamflow Data}

A comparison between measured and modeled flow data for streams in the South Coastal Basin aquifer (fig. 10) is presented in table 5. The model-calculated streamflows appear to be generally consistent with the measured annual average values for 1980 (Nixon and others, 1982), for 1995 (Ernst, 1996), and from October 2003 to September 2004 (G.C. Bent, written commun., 2004); however, because of the limited number of measurements and the large variability in measured streamflows, the model parameters were not adjusted to closely match this streamflow data.

\section{Geochemical Tracers}

In addition to water-level and streamflow data, a comparison was made between model-calculated ground-water discharge fluxes to the salt ponds and those made by an analysis of naturally occurring radium isotopes (table 6). This radium-isotope analysis is an innovative approach for estimating ground-water discharge to large coastal waters by comparing the changes in radium isotope decay rates in ground-water and saline surface-water samples obtained in the field. This approach provides ground-water flux estimates to saline surface-water bodies that are otherwise impossible to measure directly. Given the uncertainties and limiting conditions associated with the isotope method, however, model parameters were not adjusted to improve the match between modelcalculated ground-water fluxes to the salt ponds and those estimated from radium isotopes. The fluxes determined by the radium-isotope method were presented only for the purpose of comparing the two methods of estimating ground-water fluxes in areas where direct field measurements are not possible.

The use of radium isotopes for estimating submarine ground-water discharge to coastal waters has been well documented (Moore, 1996; 1997; Rama and Moore, 1996). In this approach, ground-water fluxes typically are calcu- 
Table 5. Measured streamflows for selected locations on streams in the modeled area, and the model-calculated streamflows for simulated current (1995-99) pumping and recharge conditions, South Coastal Basin aquifer, southern Rhode Island.

[Map code: Shown on figure 10. All flows in cubic feet per second]

\begin{tabular}{|c|c|c|c|c|c|}
\hline \multirow[b]{2}{*}{ Stream } & \multicolumn{3}{|c|}{ Model cell } & \multirow{2}{*}{$\begin{array}{l}\text { Measured } \\
\text { streamflow }\end{array}$} & \multirow{2}{*}{$\begin{array}{c}\text { Model- } \\
\text { calculated } \\
\text { streamflow }\end{array}$} \\
\hline & $\begin{array}{l}\text { Map } \\
\text { code }\end{array}$ & Row & Column & & \\
\hline Mill Pond & 1 & 129 & 206 & 13.0 & 0.8 \\
\hline Saugatucket & 2 & 64 & 273 & ${ }^{1} 12.9$ & 16.1 \\
\hline Saugatucket & 3 & 79 & 267 & ${ }^{1} 19.8$ & 24.0 \\
\hline Saugatucket & 4 & 88 & 263 & ${ }^{2} 10.6$ & 25.9 \\
\hline Saugatucket & 4 & 88 & 263 & ${ }^{3} 47.0$ & 25.9 \\
\hline King Tom's Pond & 5 & 119 & 151 & ${ }^{1} 1.1$ & 1.4 \\
\hline Cross Mills & 6 & 129 & 159 & ${ }^{2} 2.9$ & 2.2 \\
\hline Cross Mills & 6 & 129 & 159 & 37.5 & 2.2 \\
\hline Teal Brook & 7 & 126 & 180 & ${ }^{2} 2.2$ & 2.0 \\
\hline Teal Brook & 7 & 126 & 180 & ${ }^{3} 2.6$ & 2.0 \\
\hline Factory Brook & 8 & 128 & 181 & ${ }^{2} 1.5$ & 2.8 \\
\hline Factory Brook & 8 & 128 & 181 & ${ }^{3} 2.8$ & 2.8 \\
\hline
\end{tabular}

${ }^{1}$ G. C. Bent, U.S. Geological Survey, written commun., 2004.

${ }^{2}$ Nixon and others, 1982.

${ }^{3}$ Ernst, 1996.

Table 6. Estimated ground-water discharge to selected salt ponds in the modeled area, and the model-calculated groundwater discharge to these ponds for simulated current (1995-99) pumping and recharge conditions, South Coastal Basin aquifer, southern Rhode Island.

[All discharges in cubic feet per second]

\begin{tabular}{lcc}
\hline \multicolumn{1}{c}{ Salt pond } & $\begin{array}{c}\text { Estimated } \\
\text { ground-water } \\
\text { discharge }\end{array}$ & $\begin{array}{c}\text { Model-calculated } \\
\text { ground-water } \\
\text { discharge }\end{array}$ \\
\hline Ninigret & ${ }^{1} 13.9$ & 13.8 \\
Ninigret & ${ }^{2} 19.2$ & 13.8 \\
Green Hill & 17.6 & 3.9 \\
Green Hill & 28.9 & 3.9 \\
Trustom & 11.2 & 3.3 \\
Cards & 12.5 & 1.6 \\
Potters & 16.6 & 8.1 \\
Potters & ${ }^{2} 10.1$ & 8.1 \\
Point Judith & ${ }^{1} 28.0$ & 9.3 \\
Point Judith & ${ }^{2} 25.8$ & 9.3 \\
\hline
\end{tabular}

${ }^{1}$ Grace and Kelley, 1981.

${ }^{2}$ Scott and Moran, 2001. lated by developing a simplified model of radium, referred to herein as a box model, in which changes in radium decay rates are determined for each of the following components of the hydrologic cycle: river, coastal lagoon, coastal ocean, open ocean, and ground water. The key principle of this approach is the construction of the overall radium mass balance, such that radium enrichments (additional radium that exceeds background levels) determined for the coastal lagoons must balance the input of radium from fluvial and ground-water sources.

Several recent studies have demonstrated the potential for using naturally occurring radium isotopes as tracers of ground-water input to the coastal environment (Moore, 1996, 1997, 1999; Rama and Moore, 1996; Hussain and others, 1999; Krest and others, 2000; Scott and Moran, 2001; Charette and others, 2001; Kelly and Moran, 2002). A benefit of this approach is the well-constrained production and decay rates of radium isotopes $\left({ }^{223} \mathrm{Ra}, \mathrm{t}_{1 / 2}=11.4 \mathrm{~d} ;{ }^{224} \mathrm{Ra}, \mathrm{t}_{1 / 2}=3.6 \mathrm{~d}\right.$; ${ }^{228} \mathrm{Ra}, \mathrm{t}_{1 / 2}=5.7 \mathrm{y} ;{ }^{226} \mathrm{Ra}, \mathrm{t}_{1 / 2}=1,600 \mathrm{y}$ ), which makes them useful for determining rates of ground-water flow. ${ }^{226} \mathrm{Ra}$ is a particularly promising ground-water tracer because of its prevalence in coastal aquifers. Moreover, the differing half-lives of radium isotopes provide information on annual time scales $\left.{ }^{(228} \mathrm{Ra},{ }^{226} \mathrm{Ra}\right)$ and short-term, storm-event-driven temporal variations $\left({ }^{223} \mathrm{Ra},{ }^{224} \mathrm{Ra}\right)$ in submarine ground-water discharge.

Estimates of submarine ground-water discharge to the salt ponds may be calculated by using a simplified box model of radium in the coastal system combined with measurements of radium in ground water, salt ponds, and adjacent nearshore coastal waters (Moore, 1996; Rama and Moore, 1996; Scott and Moran, 2001; Kelly and Moran, 2002). The total excess ${ }^{226} \mathrm{Ra}$ activity $\left({ }^{226} \mathrm{Ra}_{\mathrm{ex}}\right)$ was measured in each pond on approximately 3 -month intervals through the annual cycle. Excess radium is defined as the difference between the average ${ }^{226} \mathrm{Ra}$ activity in a given salt pond and the concentration of radium measured at high tide entering the pond through the inlet connecting the pond to the open ocean. The ground-water flux is the flow required to maintain the export flux of excess ${ }^{226} \mathrm{Ra}$ from the ponds to open ocean:

$$
F_{G W}=\frac{J_{R a}}{[R a]_{G W}} \text {, }
$$

where

$F_{G W}$ is the ground-water flux, in liters per meter squared per day;

$[R a]_{G W}$ is the measured ${ }^{226} \mathrm{Ra}$ activity in ground water, in disintegrations per minute per liter; and

$J_{R a} \quad$ represents the excess ${ }^{226} \mathrm{Ra}$ flux from the salt pond, in disintegrations per minute per centimeter squared per day.

It is important to note that an assumption made in this approach that ${ }^{226} \mathrm{Ra}$ in ground water is constant, so that any variability in the rate of ${ }^{226} \mathrm{Ra}$ activity in ground water will directly affect the calculated ground-water flux, as evident in the above equation. Therefore, radium-isotope data were obtained from several locations in the salt ponds as part of an 
ongoing investigation conducted by the University of Rhode Island Graduate School of Oceanography to better constrain any temporal and/or spatial variability in radium activity in ground water. The results of this radium-isotope analysis were not available in time for use in this modeling investigation, but could be used to benefit any future modeling investigations.

\section{Simulation of Ground-Water Flow to Salt Ponds}

The numerical ground-water-flow model described earlier was used to define the areas that contribute recharge and to quantify the freshwater discharge to these coastal waters. The delineations of the recharge areas to the salt ponds and the amount of ground-water discharge, including both direct ground-water discharge and ground-water derived surfacewater discharge, were calculated by the previously described model with the understanding that the accuracy of the model is limited by the aforementioned limitations in the modelcalibration data. A series of simulations was made to determine which parameters had the largest effect on the results to identify where future data collection could be focused to improve model accuracy.

\section{Delineation of Ground-Water Recharge Areas}

All the water that discharges to any hydrologic feature in the South Coastal Basin aquifer, including pumped wells, kettle-hole ponds, streams, and coastal areas, originates as precipitation or wastewater that enters the aquifer as recharge at the water table. The area at the water table that contributes water to these hydrologic features is designated as the recharge area or contributing area to that feature. The discharge location of all water that enters the aquifer can be determined once the recharge areas to all hydrologic features are delineated. In this investigation, the USGS particle-tracking program MODPATH (Pollock, 1994) was used in conjunction with the heads and flows calculated by MODFLOW to determine the initial location of water particles that discharge to pumped wells, kettlehole ponds, streams, and coastal areas in the South Coastal Basin aquifer; this approach is similar to that used in previous investigations on Cape Cod, Mass. (fig. 11) (Masterson and Walter, 2000; Walter and others, 2004).

A comparison between the model-calculated recharge areas to the salt ponds and the watershed delineations developed by the Rhode Island SEAGRANT program (fig. 11; Ernst and others, 1999) indicates the recharge areas based on ground-water flow and the ground-water divide are similar to the watersheds based primarily on the topographic divides. Where these two delineations differed, the ground-water divide typically extended north of the topographic divide, such as near Winnapaug Pond, the western side of Ninigret Pond, Green Hill Pond, and Trustom Pond (fig. 11). It is the position of the simulated ground-water divide that represents the northernmost extent of the model-calculated recharge areas.

The difference between the ground-water and topographic divides suggests ground water is flowing from lower to higher land-surface altitude near the Charlestown Moraine, but actually, ground water is flowing from higher to lower water-table altitude in the subsurface beneath the moraine. This phenomenon is supported by the inferred water-table contours shown in the ground-water maps for these areas (LaSala and Hahn, 1960; LaSala and Johnson, 1960; Johnson, 1961a,b) and is well documented in a similar hydrogeologic setting in western Cape Cod, Mass., near the Buzzards Bay and Sandwich Moraines (Savoie, 1995; Masterson and others, 1997).

In addition to delineating the total recharge areas to each of the salt ponds, recharge areas to the streams that flow to the salt ponds and pumped wells that capture water that otherwise would discharge to salt ponds can be delineated. The recharge areas to Point Judith Pond and Green Hill Pond indicate that streamflow accounts for a significant amount of the total freshwater discharge to these ponds. In the Green Hill Pond recharge area, the pumped wells near Factory Brook Pond are removing from the aquifer water that would otherwise discharge to the pond (fig. 11).

\section{Calculation of Ground-Water Fluxes to Salt Ponds}

Under steady-state conditions, the recharge areas are delineated so that the amount of water entering the aquifer as recharge equals the amount of ground water discharging to hydrologic features:

$$
Q=R \times A,
$$

where

$Q$ is discharge, in cubic feet per second;

$R$ is the recharge rate specified in the model, in feet per second; and

$A$ is the model-calculated recharge area, in square feet.

On the basis of this concept, the ground-water model can be used to quantify the total ground-water discharge to the coast, to the individual salt ponds, and to the streams that discharge to the salt ponds (tables 7 and 8).

The total freshwater discharge to the southern coast from Westerly to Point Judith, including the direct ground-water discharge to the salt ponds and the Atlantic Ocean $\left(65 \mathrm{ft}^{3} / \mathrm{s}\right)$ and the ground-water derived surface-water flow to the South Coastal Basin streams (44 $\left.\mathrm{ft}^{3} / \mathrm{s}\right)$, is $109 \mathrm{ft}^{3} / \mathrm{s}$ (table 7). Of the $44 \mathrm{ft}^{3} / \mathrm{s}$ of streamflow that discharges to the coast, nearly 70 percent discharges into Point Judith Pond by way of the Saugatucket River and its tributaries.

Water pumped from wells and not returned to the aquifer as wastewater return flow reduces the discharge to the coast by the amount of water pumped. Only 10 percent of the $6.0 \mathrm{ft}^{3} / \mathrm{s}$ that is pumped for water supply in the study area comes from wells in the South Coastal Basin. These wells are near Factory Brook Pond (fig. 1). 


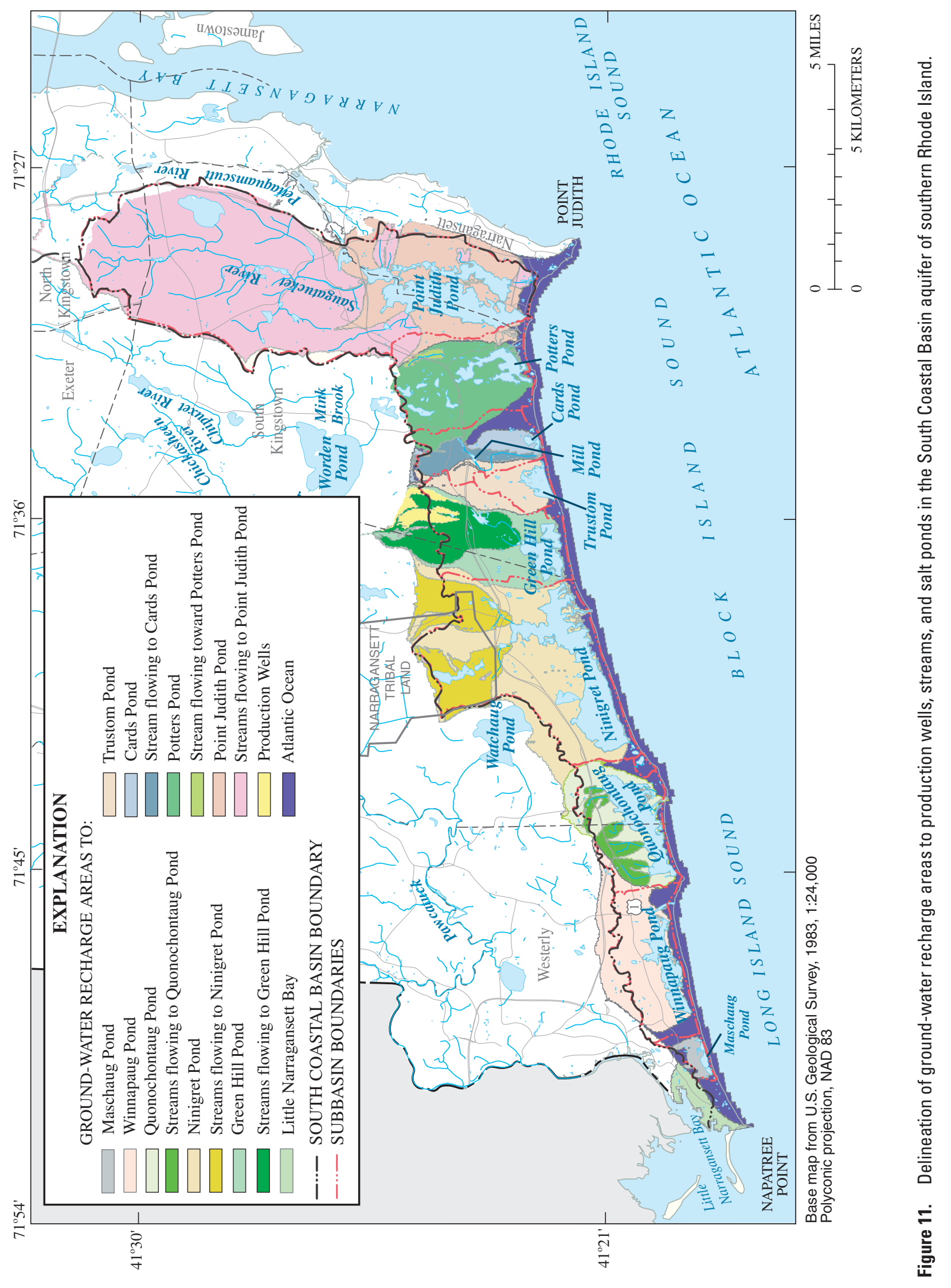


Table 7. Model-calculated hydrologic budget for the South Coastal Basin aquifer under current (1995-99) pumping and recharge conditions, southern Rhode Island.

[ft $\mathrm{ft}^{3} / \mathrm{s}$, cubic foot per second]

\begin{tabular}{lc}
\multicolumn{1}{c}{ Budget component } & $\begin{array}{c}\text { Volumetric } \\
\text { rate } \\
\left(\mathbf{f t}^{3} / \mathbf{s}\right)\end{array}$ \\
\hline \multicolumn{1}{c}{ Inflow } & \\
\hline Recharge & 221 \\
Wastewater return flow & 2 \\
Total inflow & $\mathbf{2 2 3}$ \\
\hline \multicolumn{1}{c}{ Outflow } & \\
\hline Wells & 6 \\
Streams & 91 \\
Pawcatuck and tributaries & 10 \\
Narragansett streams & 44 \\
South Coastal Basin streams & 145 \\
Total streams & \\
Coast & 65 \\
Salt Ponds/Atlantic Ocean & 7 \\
Narragansett Bay & 72 \\
Total coast & $\mathbf{2 2 3}$ \\
Total outflow &
\end{tabular}

The total discharge of freshwater to the coast can be subdivided into its separate flow components - either groundwater discharge or surface-water discharge to the individual salt ponds. The freshwater discharge ranged from as low as $0.16 \mathrm{ft}^{3} / \mathrm{s}$ to Maschaug Pond to as high as $39.64 \mathrm{ft}^{3} / \mathrm{s}$ to Point Judith Pond (highlighted columns, table 8). The distribution of direct ground-water discharge to the coast to ground-water derived surface-water (stream) discharge ranged from as high as 100 percent ground-water discharge in Maschaug, Little Maschaug, and Winnapaug Ponds to as low as 24 percent in Point Judith Pond, which is at the mouth of the Saugatucket River (fig. 1).

Model-calculated results of ground-water fluxes from this study were compared with ground-water flux values determined from previous investigations in which groundwater fluxes to the salt ponds were estimated on the basis of map-drawn recharge areas and assumed recharge rates (Grace and Kelley, 1981) and on the results of radium-isotope analyses (Scott and Moran, 2001) (table 6). The differences in the results highlight the importance of understanding the limitations and uncertainties in the methods used to quantify ground-water discharge to coastal waters.

\section{Simulation of Changes in Selected Hydraulic Parameters}

The simulated hydraulic parameters that affect the total freshwater flow to the coast and the relative proportions of direct ground-water discharge to ground-water derived surface-water discharge must be identified in order to understand the limitations or uncertainty of the ground-water flow-model simulations. Once the parameters that have the greatest effect on model-calculated coastal discharge have been identified, the effect of changes in these parameters on the calculated discharge can be determined.

One measure of determining whether the changes in the hydraulic parameters were within reasonable bounds is to compare results of the new simulations that include these changes to the measured values of water levels, pond levels, streamflows, and ground-water discharge to the salt ponds (tables 3-6). Because of limitations in the calibration data, as discussed previously in section "Model Calibration," only the water-level data from the glacial stratified deposits were considered in this analysis (table 3). It was assumed that an absolute mean residual of measured and model-calculated water levels of less than $3 \mathrm{ft}$ provided a reasonable match to the data. Furthermore, only the water levels in wells in the glacial stratified deposits south of the Charlestown Moraine (fig. 10) were used to determine model-calculated changes in response to changes in hydraulic parameters, because it is in this area of the model that the simulated changes in hydraulic parameters would have the largest effect on ground-water discharge to the salt ponds. If water-level data from wells farthest from the coast (those north of the ground-water divide) are used in the analysis of the effects of changes in model-input parameters on simulated ground-water discharge, the total change in model-calculated water levels (as expressed by the absolute mean residual values) would decrease.

\section{Effects on Total Flow to Coast}

The hydraulic parameters that have the largest effect on the total model-calculated discharge are those that affect either the recharge rate or the size of the recharge area (eq. 3). On the basis of the uncertainty analysis, it was determined that the specified recharge rate and the simulated hydraulic conductivity of the Charlestown Moraine had the largest effect on the total flow to the salt ponds.

\section{Recharge}

The distribution of recharge is difficult to quantify and may vary spatially with changes in surficial geology, hydrography, and to a lesser extent, land use. Previous investigations in nearby watersheds determined the ground-water component of total streamflow (baseflow) by a hydrograph-separation analysis of measured runoff (Barlow and Dickerman, 2001) and by the model-calculated active ground-water flow component from a precipitation-runoff model (Zarriello and Bent, 


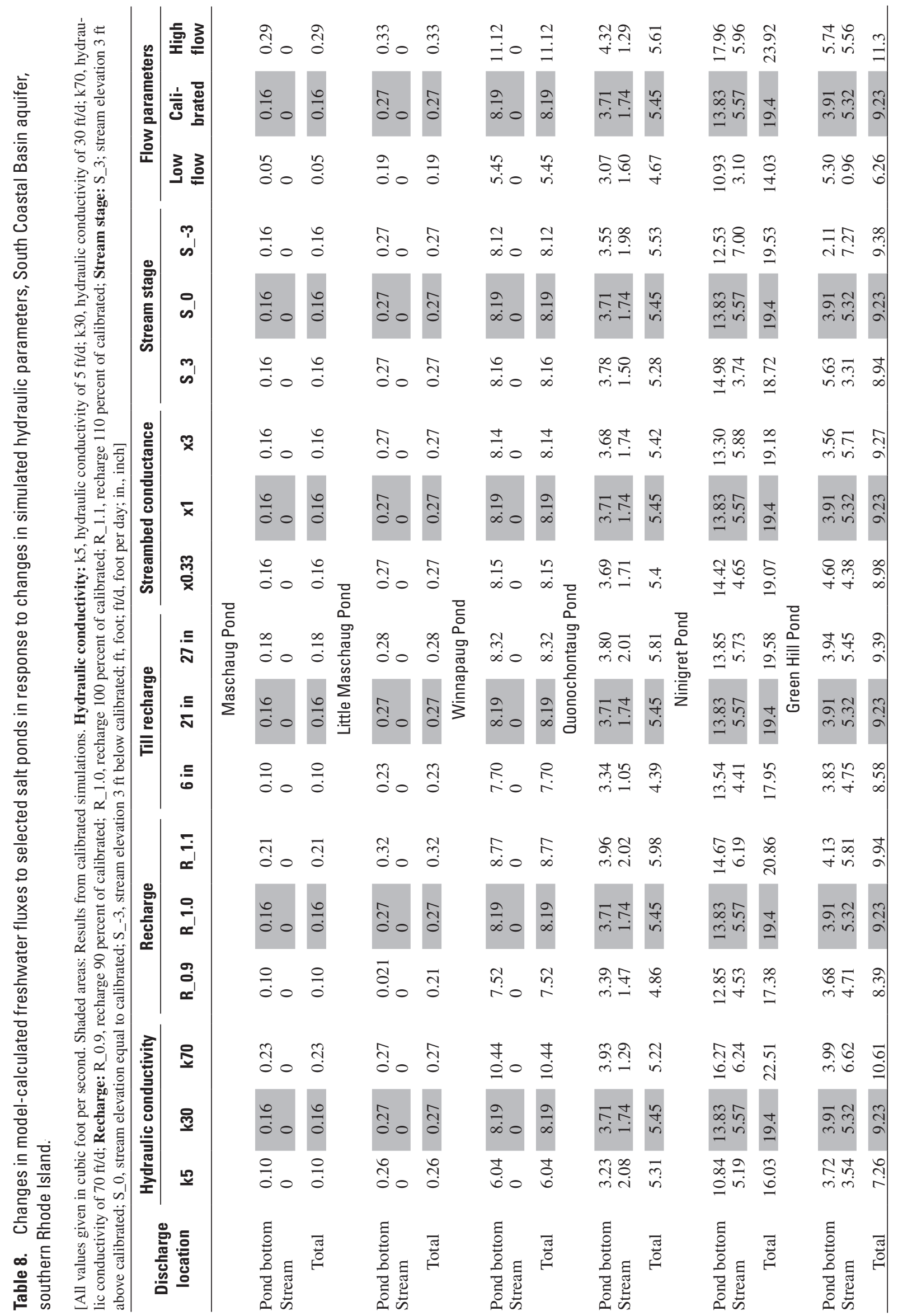




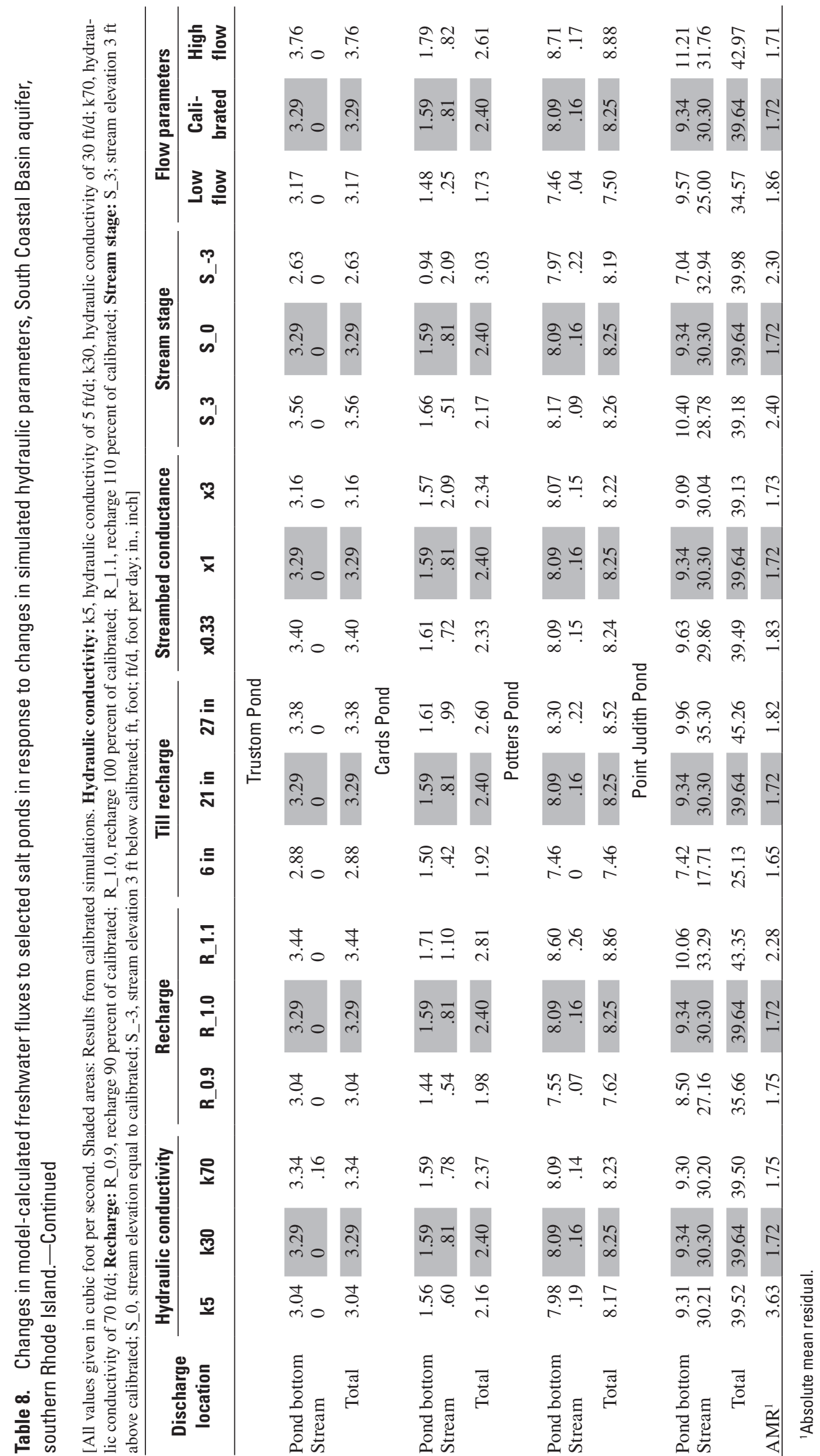


2004). Once the total ground-water flux is determined, the recharge rate over the drainage area can be estimated.

In the South Coastal Basin aquifer, unlike the aquifers in river basins north of the Pawcatuck River, the outflow of freshwater is to the coast rather than to a river, and therefore, recharge cannot be determined by the approaches described above. In this investigation, it was assumed that the recharge rate for the South Coastal Basin aquifer would be similar to that in the Pawcatuck River Basin (Zarriello and Bent, 2004) because of the similarities in hydrogeologic setting and rainfall. Given the uncertainties in specified recharge rates, the recharge rates for the South Coastal Basin were adjusted within reasonable bounds to assess the changes in model-calculated ground-water discharge rates to the ponds.

The effect of varying the specified recharge rate on total discharge to the salt ponds was attempted in a previous investigation (Grace and Kelley, 1981). In that investigation, the recharge rate was varied from $16 \mathrm{in} / \mathrm{yr}$ to $22 \mathrm{in} / \mathrm{yr}$ in the moraine and glacial stratified deposits and from 2 to $6 \mathrm{in} / \mathrm{yr}$ in the till areas. Estimates of ground-water discharge to the ponds were based on these recharge rates specified over the map-drawn recharge areas. The estimates of ground-water discharge to the salt ponds determined in that investigation are reported in table 6 and serve as the basis for nutrient-loading calculations in the Salt Pond Special Area Management Plan (Ernst and others, 1999).

An analysis similar to that of Grace and Kelley (1981) was made with the ground-water-flow model developed for this investigation. The total recharge specified in the model was varied by \pm 10 percent of the value determined for nearby river basins in previous investigations (G.C. Bent, written commun., 2004). This range in total recharge was based on the assumption that a reasonable range in recharge in the glacial stratified deposits is $27 \pm 2.7 \mathrm{in} / \mathrm{yr}$. This range was based on values reported for southern Rhode Island in previous investigations (Dickerman and others, 1997; Barlow and Dickerman, 2001; Granato and others, 2003; Friesz, 2004; Zarriello and Bent, 2004).

As the total recharge rate increased, the total freshwater discharge to the coast increased; conversely, when the total recharge rate decreased, the total freshwater discharge to the coast decreased. The discharge for each pond changed by about 10 percent, indicating that the change in discharge was related primarily to the change in recharge rate, not a change in recharge areas because changes in recharge areas were negligible. Also, even though the total discharge to the ponds varied in response to changes in the specified recharge rate, the distribution between direct ground-water discharge and ground-water derived surface-water discharge to the salt ponds generally remained constant.

The recharge rate specified in the upland till areas also was varied from $6 \mathrm{in} / \mathrm{yr}$ to $27 \mathrm{in} / \mathrm{yr}$ to account for the large uncertainty in recharge estimates for these areas. The resulting changes in ground-water discharge to the salt ponds were determined from these changes in specified recharge (table 8). The effect on ground-water discharge to the salt ponds from varying the recharge rate in upland till areas was greatest in the ponds that had large areas of upland tills in their recharge areas. These ponds include Point Judith, Trustom, and Quonochontaug Ponds (figs. 3, 11).

The pond most affected by a change in specified recharge in the upland till areas is Point Judith Pond because of the extensive upland till areas north of the pond from which the Saugatucket River flows, and because the Point Judith moraine deposits border the pond (fig. 3). In this investigation, these morainal deposits were assumed to have the same recharge rate as the upland till areas throughout the study area (fig. 3).

The total discharge to Point Judith Pond ranged from about 25 to $45 \mathrm{ft}^{3} / \mathrm{s}$ as the specified recharge in the till areas was varied from 6 to $27 \mathrm{in} / \mathrm{yr}$. Most of this change was in the streamflow to the pond (table 8). The direct ground-water discharge increased by about $2.5 \mathrm{ft}^{3} / \mathrm{s}$; the streamflow increased by about $17.6 \mathrm{ft}^{3} / \mathrm{s}$. As the recharge rate in the upland tills was increased from 6 to $27 \mathrm{in} / \mathrm{yr}$, the percentage of total freshwater discharge composed of streamflow increased from 70 to 80 percent. Because of the large effect the specified recharge rate for the upland till areas has on the total flow, understanding this process would be very important to characterizing groundwater flow to Point Judith Pond.

Changes in total recharge, and in recharge in the upland till areas, resulted in changes in the total discharge to the salt ponds, but the absolute mean residual for water levels for each of the model simulations provided a reasonable match to the calibration data set (less than $3 \mathrm{ft}$ ) (table 8). This analysis shows the effect of varying total recharge by only \pm 10 percent. The total range in specified recharge possibly could have been increased beyond \pm 10 percent and still result in a reasonable match to the calibration data; however, recharge values that deviate by more than \pm 10 percent of the rates specified in this analysis would be inconsistent with the reported recharge rates in previous studies. The fact that a larger range in simulated total recharge may still yield a reasonable match to the calibration data does not necessarily provide justification for a larger range in simulated total recharge, but rather highlights the limited accuracy of the calibration data. Therefore, because of the uncertainty in the calibration data, the model-calculated ground-water discharge to the salt ponds must include the uncertainties associated with reasonable ranges in recharge rates.

\section{Hydraulic conductivity}

In addition to changes in recharge, the effect of changes in hydraulic-conductivity values specified in the model were analyzed to determine the effect of these changes on freshwater discharge to the salt ponds. It was determined that changes in the hydraulic-conductivity values in the Charlestown Moraine and the glacial stratified deposits south of the Charlestown Moraine (fig. 3) had the largest effect on water levels and ground-water discharge to the streams and salt ponds in the South Coastal Basin aquifer. 
The hydraulic-conductivity value of the glacial stratified deposits was varied from 150 to $350 \mathrm{ft} / \mathrm{d}$ to determine the effect of this parameter on ground-water discharge. It was determined that although varying this parameter affected simulated water levels, it did not change the position of the ground-water divide and, therefore, did not affect total flow of ground water to the coast. On the basis of this analysis, a hydraulic-conductivity value of $250 \mathrm{ft} / \mathrm{d}$ provided the best match to the calibration data and, therefore, was specified in the calibrated model.

The hydraulic-conductivity value of the Charlestown Moraine was varied from 5 to $70 \mathrm{ft} / \mathrm{d}$. It was determined that this parameter did affect the position of the ground-water divide and thus the total freshwater discharge to the coast. The higher the hydraulic-conductivity value, the farther north the ground-water divide shifted toward the Pawcatuck River, resulting in larger recharge areas to the ponds and more ground-water discharge. Conversely, as the hydraulic-conductivity value for the Charlestown Moraine was decreased, the ground-water divide shifted toward to the coast, recharge areas to the ponds became smaller, and the ground-water discharge decreased.

The concept of a ground-water divide shifting in response to changes in the simulated hydraulic-conductivity values that represent the Charlestown Moraine is shown schematically in figure 12. As the hydraulic conductivity is increased, there is less resistance to flow from the stream to the coast, resulting in a shift of the ground-water divide toward to the stream (fig. 12b). In contrast, as the hydraulic conductivity is decreased, there is more resistance to flow from the stream to the coast, resulting in a shift of the ground-water divide away from the stream and toward the coast (fig. 12c).

The ponds most affected by the change in hydraulicconductivity values used to simulate the Charlestown Moraine in the flow model are Winnapaug, Ninigret, and Green Hill Ponds (fig. 1). The total freshwater discharge to Winnapaug Pond increases by nearly 75 percent from about 6.0 to $10.4 \mathrm{ft}^{3} / \mathrm{s}$ (table 8 ), as the hydraulic-conductivity value increases from 5 to $70 \mathrm{ft} / \mathrm{d}$. No streams flow into this pond, so that all freshwater discharge to the pond is from ground water. Because the recharge rate was not varied in these simulations, the change in total freshwater discharge is the result of the shift in the ground-water divide and, therefore, in the modelcalculated recharge area to this pond (fig. 13).

In the case of Ninigret and Green Hill Ponds, the change in total freshwater discharge is less than 50 percent as the hydraulic-conductivity value of the moraine increases from 5 to $70 \mathrm{ft} / \mathrm{d}$. In Ninigret Pond, where ground-water discharge accounts for most of the freshwater discharge to the pond, the total flow increases by about 40 percent, and the contribution of direct ground-water discharge to the total freshwater discharge increases from 68 to 72 percent of the total as the hydraulic conductivity is increased.

In the case of Green Hill Pond, where surface-water discharge is a substantial amount of the total flow to the pond, increases in the hydraulic conductivity of the moraine result in about a 45-percent increase in the total flow, and the contribution of surface-water discharge to the total freshwater discharge to the pond increases from 49 to 62 percent of the total flow. This result indicates that as the ground-water divide shifts farther north from the coast as the hydraulic conductivity is increased, the additional water entering the aquifer through the expanded recharge area discharges to the streams flowing to the ponds rather than flowing beneath the streams and discharging directly to the ponds. The lowering of the water table near the streams may affect where the ground water discharges along the stream channel, but the height of the water table is not low enough to result in a decrease in streamflow. Instead, the additional flow from the expanded recharge area results in additional streamflow.

The ponds east of Green Hill Pond are near the eastern extent of the Charlestown Moraine, where the moraine is farther north from the coast. Shifts in the ground-water divide in this area do not appear to result in significant changes in the total freshwater flow; therefore, recharge areas to these ponds are not affected. The hydraulic conductivity in the area of the moraine that includes the cluster of kettle-hole ponds north of Potters Pond was represented in the model with a hydraulicconductivity value of $10 \mathrm{ft} / \mathrm{d}$, the same value specified in the model for the other moraine deposit surrounding Point Judith Pond (fig. 3).

The hydraulic-conductivity value of $10 \mathrm{ft} / \mathrm{d}$, representing these moraine deposits north of Potters Pond and around Point Judith Pond, provided a better match with the pond-level data than the $30 \mathrm{ft} / \mathrm{d}$ specified in the western parts of the Charlestown Moraine. The pond-level data, unlike the water-level data, are believed to be more reliable for model calibration. This hydraulic-conductivity value of $10 \mathrm{ft} / \mathrm{d}$ was not varied as in the areas of the moraine east of Potters Pond, because the calibration match to these ponds was greater than the absolute residual error of $3 \mathrm{ft}$ when this value was varied.

Changes in the way the moraine is represented in the flow model did not appear to affect the total freshwater discharge to Quonochontaug Pond in the western part of the study area (fig. 1, table 8). As the hydraulic-conductivity value increases from 5 to $70 \mathrm{ft} / \mathrm{d}$, the percentage of direct groundwater discharge in the total freshwater discharge to the pond increases from about 60 to 75 percent; the total discharge remains nearly constant (table 8). The reason for this apparent lack of change in the total freshwater discharge to Quonochontaug Pond is the presence of streams immediately north and south of the moraine that appear to dampen the effect of simulated changes in hydraulic conductivity by limiting the shift in position of the ground-water divide. Instead of the groundwater divide shifting in response to changing water levels near the moraine, the simulated higher hydraulic-conductivity value results in lower water levels. These lower water levels reduce the amount of streamflow, but increase the amount of groundwater discharge because the water that otherwise would have discharged to the streams and then flowed to the coast is underflowing the streams and discharging directly to the coast. 
$\boldsymbol{A}$

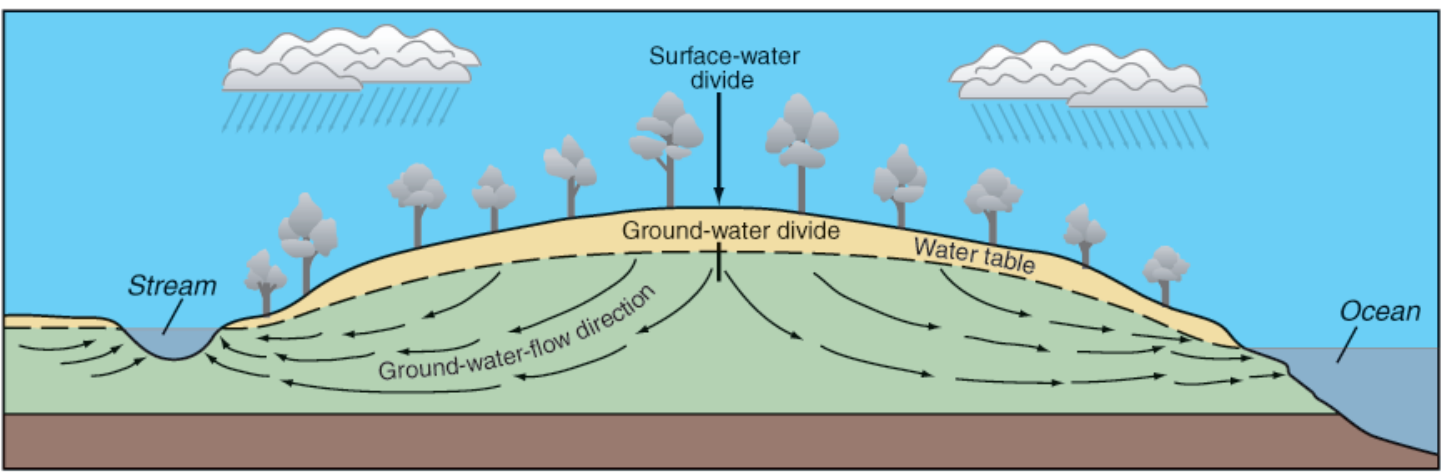

$B$

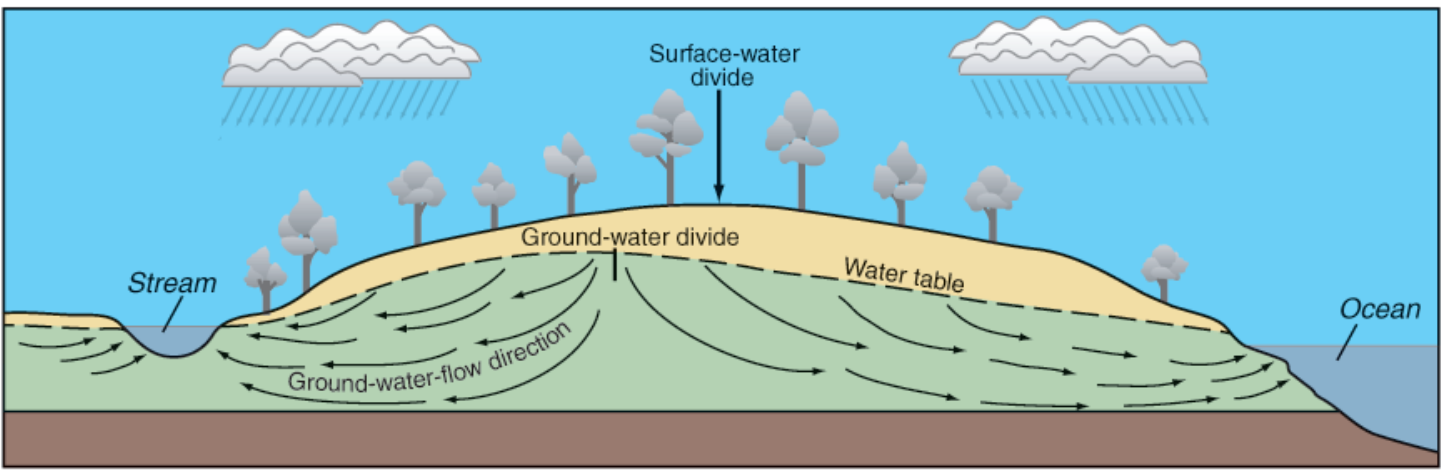

C

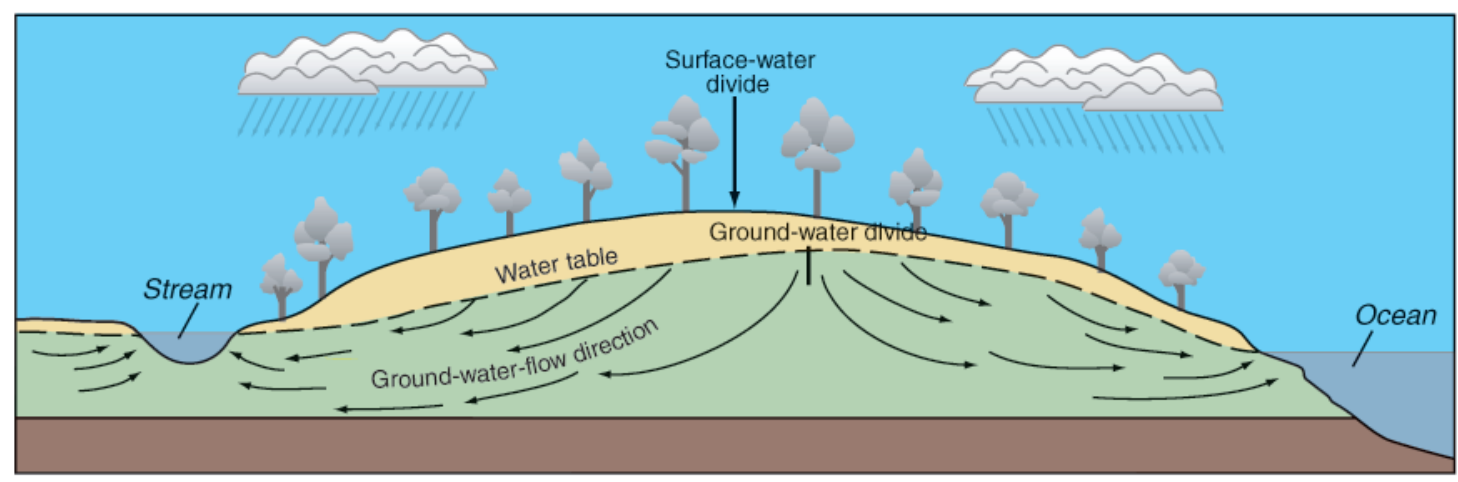

Figure 12. Diagrams showing possible ground-water flow conditions in the South Coastal Basin aquifer of southern Rhode Island where the ground-water divide is $A$, coincident with the surface-water divide; $B$, north of the surface-water divide; and $C$, south of the surface-water divide. Modified from figure 5 in Grannemann and others (2000). 


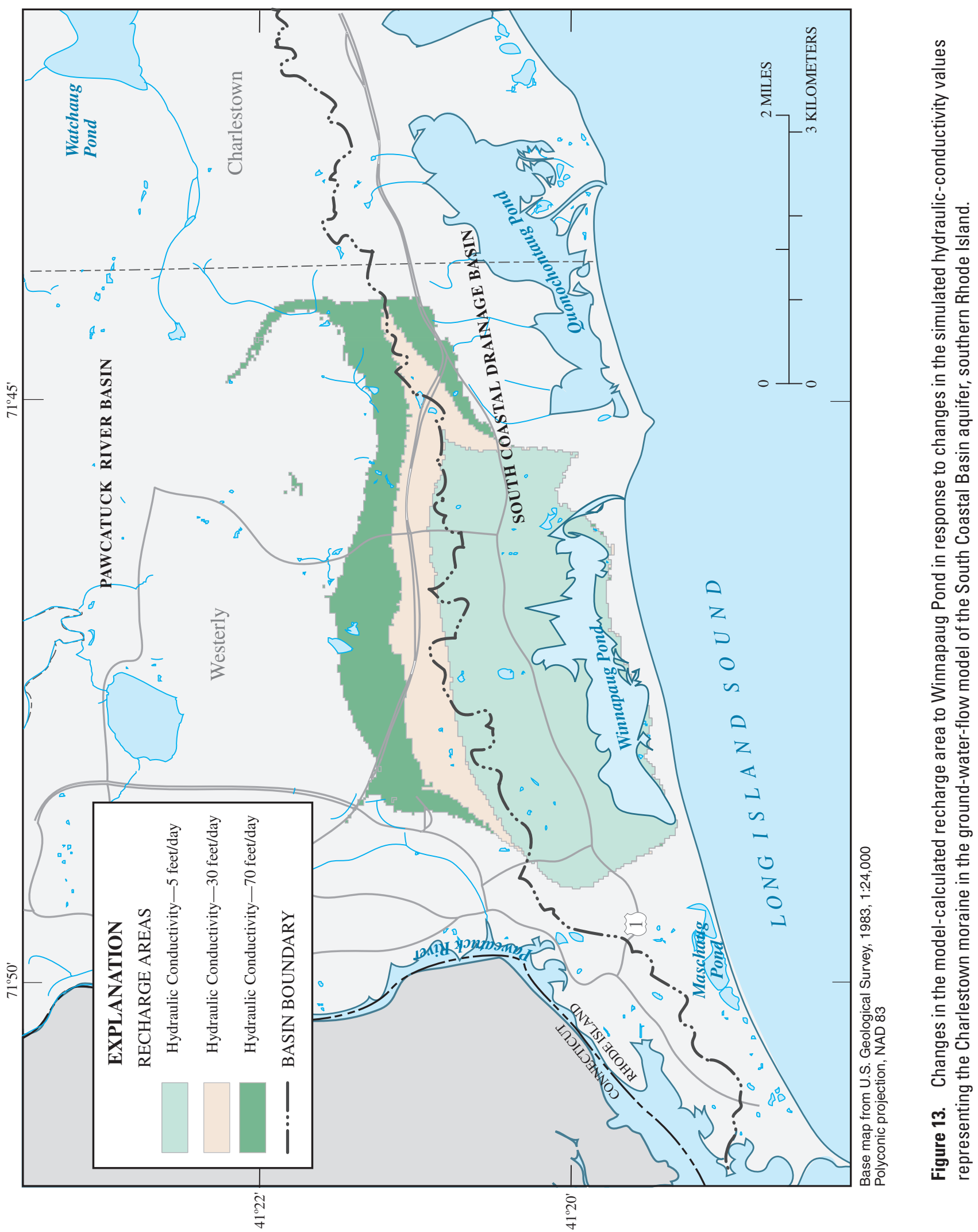


Although the changes in the simulated hydraulic conductivity resulted in substantial changes in the total discharge to several salt ponds, the changes in the model-calculated water levels were still considered calibrated when compared to the model-calibration data. More calibration data may be needed to further constrain the flow model to decrease the range in uncertainty in these model-calculated discharge values.

\section{Effects on the Distribution of Freshwater Discharge to Salt Ponds}

In addition to determining which hydraulic parameters control the total flow to the salt pond, an analysis also was made to determine the hydraulic parameters that affect the distribution of direct ground-water discharge and groundwater-derived surface-water discharge to the salt ponds. The ground-water-derived surface-water flow is referred to as streamflow. It was determined from this analysis that the hydraulic parameters substantially affecting the distribution of ground-water and surface-water flow were the simulated streambed conductance and stream stage.

Streambed conductance and stream stage are user-specified input parameters that affect the flow of water between the stream and the underlying aquifer. The streambed conductance simulates the permeability of the streambed, whereas the stream stage represents the measured water level of the stream. The difference between the specified stream stage and the model-calculated head for the model cell containing the stream multiplied by the specified streambed conductance, determines the amount of water discharging from the aquifer to the stream (eq. 1). A more detailed discussion on how these parameters were derived is provided in the section "Hydrologic Boundaries."

Given the limitations of how these parameters were derived, reasonable adjustments to these parameters were made to assess their effect on freshwater discharge to the salt ponds. The streambed-conductance value specified in the calibrated model was increased and decreased by a factor of three, and the stream stage was varied over a range of $\pm 3 \mathrm{ft}$ of the value simulated in the calibrated model. The streams in the study area were divided into two groups, one north and the other south of the Charlestown Moraine. Model simulations showed that varying the streambed conductance and stream stage in the streams north of the moraine had little effect on freshwater discharge to the salt ponds; therefore, this analysis focused on the effect of varying these parameters for the streams south of the moraine.

Model simulations showed that decreasing the streambed conductance has the same effect as increasing the stream stage - total flow to the ponds decreased slightly from the calibrated simulation and the percentage of streamflow in the total freshwater discharge decreased. This effect is the result of less total flow discharging into the streams, because more water is underflowing the streams and discharging directly to the ponds. The ponds most affected by this are those that have streams flowing to them-Ninigret, Green Hill, Point Judith, and Cards Ponds.

The slight decrease in total flow to the ponds may be the result of less ground-water flow focused toward the ponds. As less flow is captured by the streams, ground water that otherwise would have discharged to the streams discharges to the coastal areas between the ponds or to adjacent ponds. An example of this is seen in the simulation of flow near Trustom and Cards Ponds (fig. 1). Trustom Pond does not have any streams flowing into it; however, the stream flowing from Mill Pond to Cards Pond is due north of Trustom Pond and captures water that otherwise would have flowed to Trustom Pond (fig. 11). When the streambed conductance is decreased or the stream stage is increased, less water flows into the stream, but instead underflows the stream channel and discharges to Trustom Pond rather than flowing to Cards Pond. As a result, the total freshwater discharge to Trustom Pond increases as total streamflow decreases (table 8).

In Point Judith and Green Hill Ponds, streamflow accounts for most of the total freshwater discharge. As the streambed conductance and stream stage are varied so that streamflow increases, the percentage of streamflow of the total flow also increases, yet the total freshwater discharge remains nearly constant. In the case of Green Hill Pond, streamflow accounts for about 51 percent of the total freshwater flow to the pond in the calibrated model. When the stream stage is decreased from $3 \mathrm{ft}$ higher than that of the calibrated model to $3 \mathrm{ft}$ lower, the percentage of streamflow in the total freshwater flow increases from 37 to 77 percent. In the case of Point Judith Pond, streamflow accounts for about 76 percent of the total freshwater flow to the pond in the calibrated model. When the stream stage is decreased from $3 \mathrm{ft}$ higher to $3 \mathrm{ft}$ lower than that of the calibrated model, the percentage of streamflow of the total freshwater flow increases from 73 to 82 percent.

The reason for the smaller change in the percentage of streamflow to total flow in Point Judith Pond than in Green Hill Pond may be that the length and total altitude change in the Saugatucket River that flows to Point Judith is such that $\mathrm{a} \pm 3 \mathrm{ft}$ change in stream stage may affect where along the stream that ground water discharges, but does not result in a substantial change in the contribution of streamflow to the total of the freshwater flow to the pond.

An analysis of the absolute mean residual of the modelcalculated and measured water levels used for model calibration for each of these simulations suggests that all these simulated changes in streambed conductance and stream stage will provide reasonable matches to the calibration data set. Also, the changes in streamflows as a result of these changes are still within a reasonable match of the available streamflow data presented in table 5. For the ponds that receive substantial freshwater flow from streams, a better understanding of these parameters and additional measurements of streamflow over a wider range of flow than previous measurements would be required to better constrain the discharge estimates calculated by the flow model. 


\section{Effects on Ground-Water Discharge within Salt Ponds}

Understanding where submarine ground water is discharging into the salt ponds has important implications regarding nutrient transport and attenuation. In this investigation, it was assumed the ponds are underlain by a uniform deposit of low-permeability organic silts and clays except along the immediate north shoreline, where it was assumed that the pond-bottom material is similar to glaciofluvial sand and gravel deposits north of the ponds and to the deposits beneath the low-permeability material that constitutes the pond bottoms (fig. 5). Simulations made with this pond-bottom representation resulted in ground-water discharge from the pond bottom focused along the northern shore and becoming progressively less farther south from the shore, with very little discharge beyond the barrier island at the Atlantic Ocean. A simulation was then made to determine if the distribution of submarine ground-water discharge would be affected if the high-permeability zone specified along the pond shoreline was changed to that of the low-permeability material simulated throughout the ponds. The results of this simulation indicate a seaward displacement of submarine ground-water discharge beyond the northern-shore area, but no change in the total discharge to the shoreline of the Atlantic Ocean beyond the barrier island. This result suggests that ground water is still discharging to all of the ponds in spite of the low-permeability sediments simulated throughout the ponds.

The presence of this freshwater beneath the ponds is confirmed by the CRP data collected as part of this investigation (see Appendix 1); however, the distribution and amount of freshwater discharging to the ponds cannot be quantified by this geophysical technique. The CRP results served as the basis for defining the seaward extent of freshwater in the regional flow model to include the areas beneath the ponds and the barrier island to the Atlantic Ocean coastline (fig. 6). However, to characterize where freshwater discharges to an individual pond or to the ocean seaward of an individual pond requires a more detailed pond-scale study and a numerical model capable of simulating both freshwater and saltwater flow. Such an effort was beyond the scope of this investigation.

\section{Simulation of High- and Low-Flow Discharge to Salt Ponds}

The model-input parameters that provided the lowest estimates of freshwater discharge and those that provided the highest estimates of freshwater discharge were combined to assess the cumulative effect of the uncertainties of these parameters. The purpose of these simulations was to provide an estimate of the total range in flow to the ponds while satisfying the calibration criteria of an absolute mean residual in water levels of less than $3 \mathrm{ft}$ for the wells used for calibration. These parameter changes and the resulting range in flows do not necessarily represent the extreme low and high freshwater discharge calculations that could be obtained with the model while not exceeding the calibration criteria. They do, however, represent the minimum and maximum flow estimates given the range in the parameters that were considered to be reasonable for the purpose of this investigation.

The hydraulic parameters that provided low discharge values included hydraulic conductivity of the Charlestown Moraine simulated as $5 \mathrm{ft} / \mathrm{d}$, total recharge of 90 percent of the calibrated rate of $27 \mathrm{in} / \mathrm{yr}$, recharge rate in the upland till areas of $6 \mathrm{in} / \mathrm{yr}$, streambed conductance of one-third the value specified in the calibrated model, and stream stage of $3 \mathrm{ft}$ higher than that specified in the calibrated model. These input parameters will be referred to as the low-flow parameters.

The hydraulic parameters that provided high discharge values included hydraulic conductivity of the Charlestown Moraine simulated as $70 \mathrm{ft} / \mathrm{d}$, total recharge of 110 percent of the calibrated rate of $27 \mathrm{in} / \mathrm{yr}$, recharge rate in the upland till areas of $27 \mathrm{in} / \mathrm{yr}$, streambed conductance of three times the values specified in the calibrated model, and stream stage of $3 \mathrm{ft}$ lower than that specified in the calibrated model. These input parameters will be referred to as the high-flow parameters.

The total freshwater discharge to the ponds, including streamflow and direct ground-water discharge, generally increased as the model inputs were adjusted from the low-flow parameters to the high-flow parameters. This trend is shown in the change in freshwater discharge to Ninigret Pond in response to changes in the simulated hydraulic parameters (fig. 14a). An exception to this general trend is the change in the model-calculated freshwater discharge to Green Hill Pond, where the direct ground-water discharge component of the total freshwater flow decreased between the low-flow and calibrated simulations (fig. 14b). Although the direct groundwater discharge to Green Hill Pond decreased between the low-flow and calibrated simulations, the streamflow increased from about 1.0 to $5.3 \mathrm{ft}^{3} / \mathrm{s}$, and the total flow increased from about 6.3 to $9.2 \mathrm{ft}^{3} / \mathrm{s}$ (table 8 , fig. 14b). These results indicate that the changes in the hydraulic parameters that control the amount of streamflow have the largest effect on the total amount of freshwater to the pond.

The change in freshwater discharge to the ponds in response to the change in the flow parameters ranged from as low as a total range of about 18 percent in Potters Pond to as high as a range of 600 percent in Maschaug Pond. The ponds that had a change in total flow of more than 50 percent as the input parameters were adjusted from low flow to high flow include Maschaug, Little Maschaug, Winnapaug, Green Hill, Ninigret, and Cards Ponds. These ponds also were the ones most affected by changes in the hydraulic conductivity of the Charlestown Moraine.

Simulated streamflow varied by at least a factor of two between the low-flow and high-flow simulations in streams flowing to Green Hill, Ninigret, and Cards Ponds, which showed the largest range in model-calculated streamflow while still satisfying the calibration criteria specified for this 
$\boldsymbol{A}$

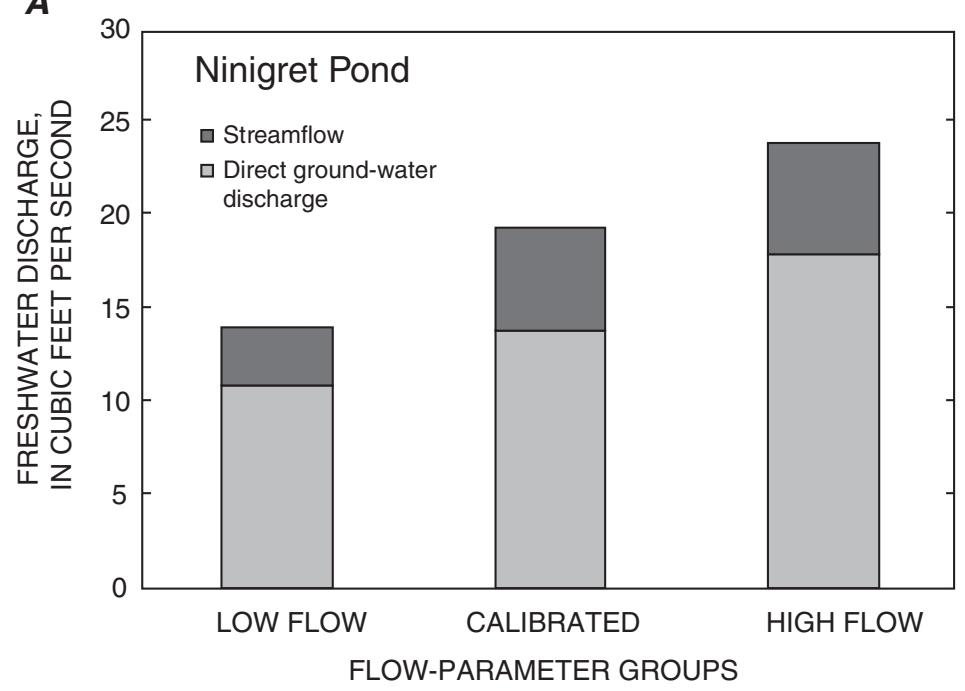

B

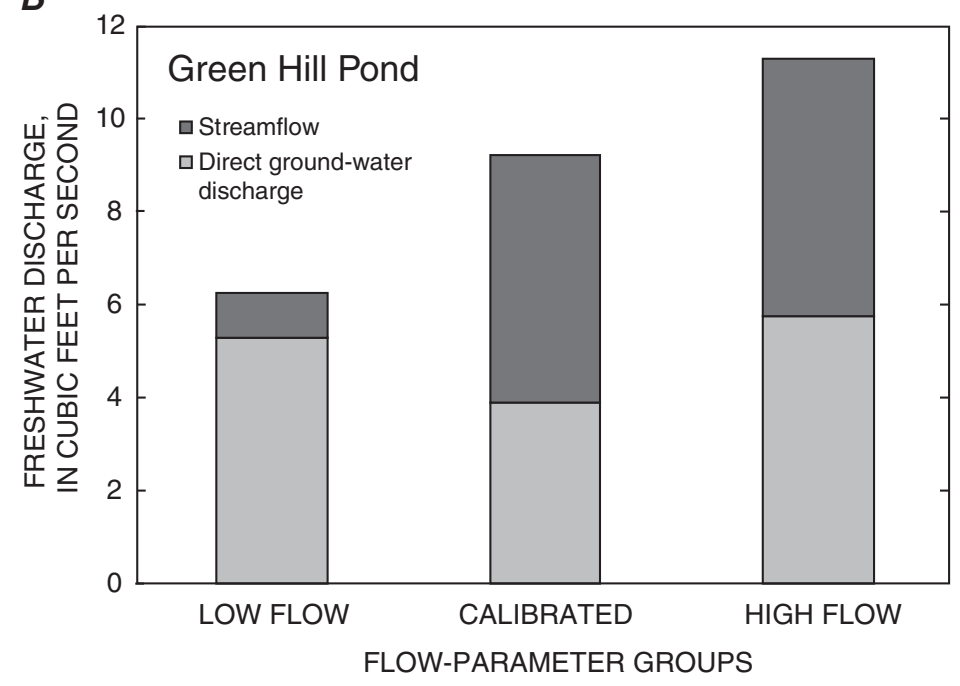

Figure 14. A, Changes in model-calculated freshwater flow to Ninigret Pond in response to changes in simulated hydraulic parameters from low- to high-flow values; and $B$, changes in model-calculated freshwater flow to Green Hill Pond in response to changes in simulated hydraulic parameters from low- to high-flow values. Both ponds are in southern Rhode Island. 
analysis. The streamflow data used as part of the model calibration included the flow measurements made from July 1994 to May 1995 (Ernst, 1996). The range in streamflow estimates from these low- and high-flow simulations compares favorably with the range in measured values for the 1994-95 period; however, a longer period of measurements would be needed to determine more accurate long-term average flows for these streams.

\section{Summary and Conclusions}

The Salt Pond region of southern Rhode Island extends from Westerly to Narragansett and forms the natural boundary between the Atlantic Ocean and the shallow, highly permeable freshwater aquifer of the South Coastal Basin. This is one of the fastest growing areas in the State, and development pressure is such that undeveloped areas continue to be converted to residential uses. Ground-water discharge from the South Coastal Basin aquifer to the salt ponds is an important though poorly quantified source of contaminants, such as dissolved nutrients. Large inputs of freshwater discharge and the low flushing rates to the open ocean make the salt ponds particularly susceptible to eutrophication and bacterial contamination. Because of the limitations in previous methods used to characterize the sources of water to the salt ponds and the growing concerns over the deleterious effects of eutrophication to this coastal resource, the U. S. Geological Survey began a 2-year investigation in 2003 in cooperation with the Rhode Island Coastal Resources Management Council to improve the regional understanding of the hydrogeologic framework and ground-water flow in the Salt Pond region of southern Rhode Island.

The coastal region of southern Rhode Island consists of thick deposits of glacially derived boulders, sands, silts, and clays. The predominant geologic feature in the region is the east-west trending Charlestown Moraine. This moraine serves as both the ground-water and surface-water divides for water flows in the area between the Pawcatuck River and the coast. Therefore, it represents the northernmost extent of most of the watersheds for the coastal areas of the Salt Pond region.

A ground-water-flow model was developed and used to delineate the areas that contribute ground-water recharge to the salt ponds and the streams that flow into them, and to calculate ground-water fluxes to these coastal areas for long-term average conditions. A detailed interpretation of the geologic setting of southern Rhode Island and a field investigation that used continuous resistivity profiling to determine the seaward extent of submarine ground-water discharge were incorporated into a simplified numerical representation of the regional hydrogeologic framework.
As part of the modeling analysis, adjustments were made to model-input parameters within reasonable bounds to assess potential changes in model-calculated watershed delineations and ground-water discharge to salt ponds. The ground-waterflow model also was used for evaluating the appropriateness of the existing map-drawn watersheds of the salt ponds, providing estimates of ground-water fluxes to the salt ponds, and identifying reasonable uncertainties in these model-calculated flux values in light of the limited hydrogeologic data for the study area.

All the methods used to determine watershed delineations and estimates of ground-water discharge to the salt ponds are subject to simplifying assumptions, and their accuracy is controlled by the available hydrogeologic data from which the delineations are derived. Unlike the mapdrawn watershed-delineation approach, a ground-water-model approach allows for evaluating the effects of selected hydraulic parameters on the model simulations within the context of the existing hydrogeologic data. This approach allows a reasonable determination of the uncertainty of the simulation results.

The uncertainty in the predictions of ground-water discharge to the salt ponds can be reduced by collecting additional hydrogeologic data, such as water levels, streamflows, and lithologic borings. This information would help constrain the model parameters that appear to have the greatest effect on the simulation results.

Simulated results indicate that:

(1) Simulated total flow to the salt ponds is affected primarily by the ease with which water is transmitted through the Charlestown Moraine. When the moraine was assigned a lower transmissivity, the ground-water divide shifted toward the coast and discharge to the salt ponds decreased. Conversely, when the moraine was assigned a higher transmissivity, the ground-water divide shifted away from the coast, and discharge to the salt ponds increased.

(2) Changes in the specified recharge rate also affect the total flow to the salt ponds, but the areas that contribute ground water to the salt ponds remain unchanged.

(3) Simulated stream characteristics, including the streambed-aquifer connection and the stream stage, affect the distribution in the total freshwater flow between direct ground-water discharge and ground-water-derived surfacewater (streamflow) discharge to the salt ponds. Changes in simulated stream characteristics do not have a substantial effect on the total freshwater flow to the coast.

(4) Reasonable changes in simulated hydraulic parameters can have substantial effects on total freshwater discharge, the distribution of direct ground-water discharge, and streamflow discharge to the salt ponds, but can still provide a reasonable match to the hydrologic data available for model calibration. 


\section{Acknowledgments}

The authors wish to thank USGS colleagues Robert F. Breault, John A. Colman, Timothy D. McCobb, and Eric White for their assistance throughout the investigation, and Jeff Meunier, of Express, Inc., for his assistance in the collecting and processing geophysical data. Also, the authors wish to thank the staff at Ocean House Marina in Charlestown, RI, for the use of their boat launch throughout the investigation.

\section{References Cited}

Anderson, M.P., and Woessner, W.W., 1992, Applied groundwater modeling: Academic Press, Inc., San Diego, CA, 381 p.

Barlow, P.M., 2003, Ground water in freshwater-saltwater environments of the Atlantic Coast: U.S. Geological Survey Circular 1262, 113 p.

Barlow, P.M., and Dickerman, D.C., 2001, Numerical-simulation and conjunctive-management models of the HuntAnnaquatucket-Pettaquamscutt stream-aquifer system, Rhode Island: U.S. Geological Survey Professional Paper $1636,88 \mathrm{p}$.

Bierschenk, W.H., 1956, Ground-water resources of the Kingston quadrangle, Rhode Island: Rhode Island Water Resources Board Geological Bulletin 9, 60 p., 3 pls., scale 1:24,000.

Boothroyd, J.C., Friedrich, N.E., and McGinn, S.R., 1985, Geology of microtidal coastal lagoons: Rhode Island, in Oertel, G.F., and Leatherman, S.P., eds., Barrier Islands: Marine Geology, v. 63, p. 35-76.

Boothroyd, J.C., Freedman, J.H., Brenner, H.B., and Stone, J.R., 1998, The glacial geology of southern Rhode Island, in Murray, D.P., ed., 1998 New England Intercollegiate Geological Conference, 90th annual meeting, Kingston, RI, October 9-11, 1998, Guidebook for fieldtrips in Rhode Island and adjacent regions of Connecticut and Massachusetts: trip C5, 25 p.

Charette, M.A., Buesseler, K.O., and Andrews, J.E., 2001, Utility of radium isotopes for evaluating the input and transport of groundwater-derived nitrogen to a Cape Cod estuary: Limnology and Oceanography, v. 46, p. 465-470.

DeSimone, L.A., 2004, Simulation of ground-water flow and evaluation of water-management alternatives in the Assabet River Basin, Eastern Massachusetts: U.S. Geological Survey Scientific Investigations Report 2004-5114, 142 p.
DeSimone, L.A., Walter, D.A., Eggleston, J.R., and Nimiroski, M.T., 2002, Simulation of ground-water flow and evaluation of water-management alternatives in the upper Charles River Basin, eastern Massachusetts: U.S. Geological Survey Water-Resources Investigations Report 02-4234, 94 p.

Dickerman, D.C., Kliever, J.D., and Stone, J.R., 1997, Hydrogeology, water quality, and simulation of ground-waterdevelopment alternatives in the Usquepaug-Queen groundwater reservoir, southern Rhode Island: U.S. Geological Survey Water- Resources Investigations Report, 97-4126, $48 \mathrm{p}$.

Dickerman, D.C., Todd, E.C.T., and Russell, J.P., 1990, Hydrogeology, water quality, and ground-water development alternatives in the Lower Wood River ground-water reservoir, Rhode Island: U.S. Geological Survey WaterResources Investigations Report 89-4031, 109 p.

Dillon, W.P., 1970, Submergence effects on a Rhode Island barrier and lagoon and inferences on migration of barriers: Journal of Geology, v. 78, p. 94-106.

Ernst, L.M., Miguel, L. K., and Willis, J., 1999, Rhode Island's Salt Pond Region: A special area management plan: Wakefield, Rhode Island, Rhode Island Coastal Resources Management Council, 224 p.

Ernst, L.M., 1996, The cumulative impacts of management decisions on nitrogen loading to the Rhode Island salt ponds: University of Rhode Island, Master of Arts in Marine Affairs, variously paged.

Ernst, L. M. and Lee, V., 1995, Field measurements: Narragansett, R.I., University of Rhode Island Coastal Resources Center.

Farnsworth, R.K., Thompson, E.S., and Peck, E.L., 1982, Evaporation atlas for the contiguous 48 United States: U.S. Department of Commerce, National Oceanic and Atmospheric Administration, Technical Report NWS 33, 26 p., 4 pls.

Friesz, P.J., 2004, Delineation of areas contributing recharge to selected public-supply wells in glacial valley-fill and wetland settings, Rhode Island: U.S. Geological Survey Scientific Investigations Report 2004-5070, 64 p.

Giblin, A.E., and Gaines, A.G., 1990, Nitrogen inputs to a marine embayment: the importance of groundwater: Biogeochemistry, v. 10, p. 309-328.

Gonthier, J.B., Johnston, H.E., and Malmberg, G.T., 1974, Availability of ground water in the Lower Pawcatuck River Basin, Rhode Island: U.S. Geological Survey Water-Supply Paper 2033, 40 p., 4 pls. 
Grace, J., and Kelley, W., 1981, Fresh water input to Rhode Island coastal ponds: Narragansett, R.I, Report to University of Rhode Island Coastal Resources Center, 16 p.

Granato, G.E., Barlow, P.M., and Dickerman, D.C., 2003, Hydrogeology and simulated effects of ground-water withdrawals in the Big River area, Rhode Island: U.S. Geological Survey Water-Resources Investigations Report 03-4222, 76 p.

Grannemann, N.G., Hunt, R.J., Nicholas, J.R., Reilly, T.E., and Winter, T.C., 2000, The importance of ground water to the Great Lakes Region: U.S. Geological Survey Water-Resources Investigations Report 00-4008, 12 p.

Hahn, G.W., 1959, Narragansett Pier quadrangle, Rhode Island: Rhode Island Water Resources Board Ground-Water Map 5, 1 pl., scale 1:24,000.

Hermes, O.D., Gromet, L.P., and Murray, D.P., comps., 1994, Bedrock geologic map of Rhode Island: Rhode Island Map Series No. 1, University of Rhode Island, Kingston, scale 1:100,000.

Harbaugh, A.W., and McDonald, M.G., 1996, User's documentation for MODFLOW-96, an update to the U.S.Geological Survey modular three-dimensional finite difference ground-water-flow model: U.S. Geological Survey Open-File Report 96-485, 56 p.

Hussain, N., Church, T.M., and Kim, G., 1999, Use of 222Rn and 226Ra to trace groundwater discharge into the Chesapeake Bay: Marine Chemistry, v. 65, p. 127-134.

Johannes, R.E., 1980, The ecological significance of submarine discharge of groundwater: Marine Ecology Progress Series, v. 3, p. 365-373.

Johnson, K.E., 1961a, Watch Hill quadrangle, Connecticut-Rhode Island: Rhode Island Water Resources Board Ground-Water Map 14, 1 pl., scale 1:24,000.

Johnson, K.E., 1961b, Rhode Island part of the Ashway quadrangle and some areas of Connecticut: Rhode Island Water Resources Board Ground-Water Map 16, 1 pl., scale 1:24,000.

Johnson, K.E., and Marks, L.Y., 1959, Wickford quadrangle, Rhode Island: Rhode Island Water Resources Board Ground-Water Map 1, 1 pl., scale 1:24,000.

Kaye, C.A., 1960, Surficial geology of the Kingston quadrangle, Rhode Island: U.S. Geological Survey Bulletin 1071I, scale 1:24,000, with accompanying text.

Kelly, R.P., and Moran S.B., 2002, Seasonal changes in groundwater input to a well-mixed estuary estimated using radium isotopes and implications for coastal nutrient budgets: Limnology and Oceanography, v. 47, no. 6, p. 1796-1807.
Krest, J.M., Moore, W.S., Gardner, L.R., and Morris, J.T., 2000, Marsh nutrient export supplied by groundwater discharge - evidence from radium measurements: Global Biogeochemical Cycles, v. 14, p. 167-176.

Konikow, L.F., and Reilly, T.E., 1999, Groundwater modeling, in Delleur, J.W., ed., The handbook of groundwater engineering: Boca Raton, Fla., CRC Press, 40 p.

Lang, S.M., Bierschenk, W.H., and Allen, W.B., 1960, Hydraulic characteristics of glacial outwash in Rhode Island: Rhode Island Water Resources Board Hydrologic Bulletin 3, 38 p.

LaSala, A.M., Jr., and Hahn, G.W., 1960, Carolina quadrangle, Rhode Island: Rhode Island Water Resources Board Ground-Water Map 9, 1 pl., scale 1:24,000.

LaSala, A.M., Jr., and Johnson, K.E., 1960, Quonochontaug quadrangle, Rhode Island: Rhode Island Water Resources Board Ground-Water Map 11, 1 pl., scale 1:24,000.

Lee, V., and Olsen, S., 1984, Eutrophication and the management initiatives for the control of nutrient inputs to Rhode Island Coastal lagoons: Estuaries, v. 8, p. 191-202.

Masterson, J.P., 2004, Simulated interaction between freshwater and saltwater and effects of ground-water pumping and sea-level change, Lower Cape Cod aquifer system, Massachusetts: U.S. Geological Survey Scientific Investigations Report 2004-5014, 78 p.

Masterson, J.P., and Walter, D.A., 2000, Delineation of groundwater recharge areas, western Cape Cod, Massachusetts: U.S. Geological Survey Water-Resources Investigations Report 00-4000, 1 pl.

Masterson, J.P., Stone, B.D., Walter, D.A., and Savoie, Jennifer, 1997, Hydrogeologic framework of western Cape Cod, Massachusetts: U.S. Geological Survey HydrologicInvestigations Atlas 741, $1 \mathrm{pl}$.

McDonald, M.G., and Harbaugh, A.W., 1988, A modular three-dimensional finite-difference ground-water flow model: U.S. Geological Survey Techniques of WaterResources Investigations, book 6, chap. A1, 586 p.

Melvin, R.L., de Lima, Virginia, and Stone, B.D., 1992, The stratigraphy and hydraulic properties of till in southern New England: U.S. Geological Survey Open-File Report 91-481, 53 p.

Moore, W.S., 1996, Large groundwater inputs to coastal waters revealed by $226 \mathrm{Ra}$ enrichments: Nature, v. 380 , p. 612-614.

Moore, W.S., 1997, 226Ra, 228Ra, 223Ra, and 224Ra in coastal waters with application to coastal dynamics and groundwater input: Radioprotection, v. 32, no. C2, p. 137-146. 
Moore, W.S., 1999, The subterranean estuary-a reaction zone of ground water and sea water: Marine Chemistry, v. 65, p. 111-125.

Mullaney, J.R., 2004, Water use, ground-water recharge and availability, and quality of water in Greenwich area, Fairfield County, Connecticut, and Westchester County, New York, 2000-2002: U.S. Geological Survey Water-Resources Investigations Report 03-4300, 71 p.

National Oceanic and Atmospheric Administration, 2003, Normals, means, and extremes: Providence, R.I., accessed December 10, 2003, at http://www.erh.noaa.gov/box/ climate/PROVIDENCE_RI_html

Needell, S.W., and Lewis, R.S., 1984, Geology and structure of Block Island Sound, R.I. and N.Y.: U.S. Geological Survey Miscellaneous Field Studies Map MF-1621, scale 1:125,000.

Nixon, S.W., Furnas, B., Chinman, R., Granger, S., and Hefferman, S., 1982, Nutrient inputs to Rhode Island coastal lagoons and salt ponds: Narragansett, RI, Final report to Rhode Island Statewide Planning, variously paged.

Olsen, S., and Lee, V., 1984, The Salt Pond Region Special Area Management Plan: Wakefield, Rhode Island, Rhode Island Coastal Resources Management Council, variously paged.

Peck, J.A., and McMaster, R.L., 1991, Stratigraphy and geologic history of Quaternary sediments in lower West Passage, Narragansett Bay, Rhode Island: Fort Lauderdale, Fla., Journal of Coastal Research, v. SI-11, p. 25-37.

Persky, J.H., 1986, The relation of groundwater quality to housing density, Cape Cod, Massachusetts: U.S. Geological Survey Water-Resources Investigations Report 86-4093, $22 \mathrm{p}$.

Pollock, D. W., 1994, User's guide to MODPATH/MODPATH_PLOT, version 3-A particle tracking post-processing package for MODFLOW, the U. S. Geological Survey modular three-dimensional finite-difference groundwaterflow model: U.S. Geological Survey Open-File Report 94-464, 234 p.
Rama and Moore, W.S., 1996, Using the radium quartet for evaluating groundwater input and water exchange in salt marshes: Geochimica et Cosmochimica Acta, v. 60, p. 4645-4652.

Reilly, T.E., and Harbaugh, A.W., 2004, Guidelines for evaluating ground-water flow models: U.S. Geological Survey Scientific Investigations Report 2004-5038, 30 p.

Reilly, T.E., 2001, System and boundary conceptualization in ground-water flow simulation: U.S. Geological Survey Techniques of Water-Resources Investigations, book 3, chap. B8, 38 p.

Rhode Island Sea Grant Program, 2001, South Shore Research Collaborative-Outcomes of the December 3rd and 4th Workshops: accessed on July 21, 2005, at http://seagrant. gso.uri.edu/coasts/workshopoutputs.pdf

Savoie, J.G., 1995, Altitude and configuration of the water table, western Cape Cod, Massachusetts, March 1993: U.S. Geological Survey Open-File Report 94-462, 1 sheet, scale $1: 50,000$.

Scott, M.K., and Moran, S.B., 2001, Groundwater input to coastal salt ponds of southern Rhode Island estimated using 226Ra as a tracer: Journal of Environmental Radiation, v. 54, p. 163-174.

Schafer, J.P., 1961, Surficial geology of the Narragansett Pier quadrangle, Rhode Island: U.S. Geological Survey Quadrangle Map GQ-140, scale 1:24,000, with accompanying text.

Schafer, J.P., 1965, Surficial geology of the Watch Hill quadrangle, Rhode Island: U.S. Geological Survey Quadrangle Map GQ-410, scale 1:24,000.

Sewell, P.L., 1982, Urban groundwater as a possible nutrient source for an estuarine benthic algal bloom: Estuaries, Coastal and Shelf Science, v. 15, p. 569-576.

Socolow, R.S., Comeau, L.Y., and Murino, Domenic, 2004, Water resources data, Massachusetts and Rhode Island, Water Year 2004: U.S. Geological Survey Water Data Report MA-RI-04-1, 326 p. 
Stone, B.D., and Borns, H., 1986, Pleistocene glacial and interglacial stratigraphy of New England, Long Island, and adjacent Georges Bank and Gulf of Maine, in Sibrava, Vladimir, Bowen, D.Q., and Richmond, G.M., eds., Quaternary glaciations in the Northern Hemisphere: Oxford, United Kingdom, Pergamon Press, p. 39-52.

Walter, D.A., Masterson, J.P., and Hess, K.M., 2004, Groundwater recharge areas and travel times to pumped wells, ponds, streams, and coastal water bodies, Cape Cod, Massachusetts: U.S. Geological Survey Scientific Investigations Map I-2857, 1 sheet.

Walter, D.A., and Whelan, A.T., 2004, Simulated water sources and effects of pumping on surface and ground water, Sagamore and Monomoy flow lenses, Cape Cod, Massachusetts: U.S. Geological Survey Scientific Investigations Report 2004-5181, 85 p.
Wild, E.C., and Nimiroski, M.T., 2004a, Estimated water use and availability in the Pawcatuck River Basin, southern Rhode Island and southeastern Connecticut: U.S. Geological Survey Scientific Investigations Report 2004-5020, $72 \mathrm{p}$.

Wild, E.C., and Nimiroski, M.T., 2004b, Estimated water use and availability in the South Coastal Drainage Basin, southern Rhode Island, 1995-99: U.S. Geological Survey Scientific Investigations Report 2004-5288, 46 p.

Zarriello, P.J., and Bent, G.C., 2004, A precipitation-runoff model for the analysis of the effects of water withdrawals and land-use change on streamflow in the UsquepaugQueen River Basin, Rhode Island: U.S. Geological Survey Scientific Investigations Report 2004-5139, 86 p. 
Table 3. Measured water levels for selected observation wells in the modeled area (1954-61), and the model-calculated waterlevel altitudes for simulated current (1995-99) pumping and recharge conditions, South Coastal Basin aquifer, southern Rhode Island.

[Well locations shown on figure 10. ID: identifier. Residual: Residual equals measured minus model-calculated. Water-level values are in feet relative to NGVD29.]

\begin{tabular}{|c|c|c|c|c|c|c|}
\hline \multirow{2}{*}{ Well ID } & \multicolumn{3}{|c|}{ Model cell } & \multicolumn{3}{|c|}{ Water levels } \\
\hline & Row & Column & Layer & Measured & Model-calculated & Residual \\
\hline \multicolumn{7}{|c|}{ South Coastal Basin Observation Wells } \\
\hline SNW-1-33 & 114 & 182 & 1 & 33.00 & 31.90 & 1.10 \\
\hline SNW-1-34 & 114 & 188 & 1 & 34.00 & 30.54 & 3.46 \\
\hline CHW-280 & 117 & 154 & 1 & 20.00 & 13.05 & 6.95 \\
\hline SNW-1-26 & 117 & 183 & 1 & 26.00 & 26.19 & -.19 \\
\hline SNW-1-28 & 117 & 192 & 1 & 28.00 & 27.06 & .94 \\
\hline CHW-290 & 118 & 170 & 1 & 17.00 & 17.99 & -.99 \\
\hline CHW-202 & 119 & 149 & 1 & 17.00 & 13.31 & 3.69 \\
\hline CHW-139 & 119 & 156 & 1 & 9.00 & 8.12 & .88 \\
\hline CHW-124 & 119 & 159 & 1 & 15.00 & 10.84 & 4.16 \\
\hline SNW-1-24 & 119 & 183 & 1 & 24.00 & 21.32 & 2.68 \\
\hline CHW-121 & 120 & 166 & 1 & 13.00 & 12.66 & .33 \\
\hline SNW-1-5 & 120 & 229 & 1 & 5.00 & 6.76 & -1.76 \\
\hline SNW-1-17 & 121 & 182 & 1 & 17.00 & 15.79 & 1.21 \\
\hline SNW-1-20 & 121 & 185 & 1 & 20.00 & 17.95 & 2.05 \\
\hline SNW-1-22 & 121 & 192 & 1 & 22.00 & 21.95 & .05 \\
\hline SNW-1-29 & 121 & 202 & 1 & 29.00 & 26.39 & 2.61 \\
\hline CHW-132 & 122 & 163 & 1 & 13.00 & 9.64 & 3.36 \\
\hline SNW-1-13 & 123 & 176 & 1 & 13.00 & 9.51 & 3.49 \\
\hline SNW-1-10 & 123 & 180 & 1 & 10.00 & 10.71 & -.71 \\
\hline CHW-1-011 & 124 & 172 & 1 & 11.00 & 10.36 & .64 \\
\hline SNW-1-20 & 124 & 216 & 1 & 20.00 & 22.01 & -2.01 \\
\hline CHW-282 & 125 & 140 & 1 & 15.00 & 17.09 & -2.09 \\
\hline CHW-020 & 125 & 143 & 1 & 16.00 & 15.15 & .84 \\
\hline SNW-1-10 & 125 & 223 & 1 & 10.00 & 12.59 & -2.59 \\
\hline SNW-1-5 & 126 & 182 & 1 & 5.00 & 5.37 & -.37 \\
\hline CHW-140 & 127 & 152 & 1 & 2.00 & 2.25 & -.25 \\
\hline SNW-1-7 & 127 & 185 & 1 & 7.00 & 8.89 & -1.89 \\
\hline CHW-018 & 128 & 144 & 1 & 8.24 & 11.37 & -3.13 \\
\hline CHW-216 & 128 & 150 & 1 & 4.00 & 3.60 & .40 \\
\hline CHW-1-002 & 128 & 171 & 1 & 2.00 & 5.14 & -3.14 \\
\hline SNW-1-15 & 128 & 206 & 1 & 15.00 & 11.21 & 3.79 \\
\hline SNW-1-2 & 129 & 181 & 1 & 2.00 & 2.20 & -.20 \\
\hline CHW-218 & 130 & 160 & 1 & 2.00 & 3.19 & -1.19 \\
\hline CHW-220 & 130 & 163 & 1 & 5.00 & 4.45 & .55 \\
\hline SNW-1-8 & 130 & 215 & 1 & 8.00 & 12.14 & -4.14 \\
\hline CHW-164 & 131 & 131 & 1 & 4.00 & 5.10 & -1.10 \\
\hline CHW-201 & 131 & 149 & 1 & 3.00 & 3.10 & -.10 \\
\hline CHW-129 & 131 & 168 & 1 & 3.00 & 3.95 & -.95 \\
\hline SNW-1-2 & 131 & 183 & 1 & 2.00 & 3.00 & -1.00 \\
\hline SNW-1-3 & 131 & 202 & 1 & 3.00 & 6.60 & -3.60 \\
\hline
\end{tabular}


Table 3. Measured water levels for selected observation wells in the modeled area (1954-61), and the model-calculated waterlevel altitudes for simulated current (1995-99) pumping and recharge conditions, South Coastal Basin aquifer, southern Rhode Island._-Continued

[Well locations shown on figure 10. ID: identifier. Residual: Residual equals measured minus model-calculated. Water-level values are in feet relative to NGVD29.]

\begin{tabular}{|c|c|c|c|c|c|c|}
\hline Well ID & \multicolumn{3}{|c|}{ Model cell } & \multicolumn{3}{|c|}{ Water levels } \\
\hline CHW-330 & 132 & 146 & 1 & 4.00 & 4.18 & -0.18 \\
\hline CHW-113 & 134 & 168 & 1 & 1.00 & 2.14 & -1.14 \\
\hline SNW-1-0 & 134 & 179 & 1 & 0.00 & 1.53 & -1.53 \\
\hline SNW-1-1 & 135 & 211 & 1 & 1.00 & 3.46 & -2.46 \\
\hline SNW-1-2 & 135 & 221 & 1 & 2.00 & 3.07 & -1.07 \\
\hline CHW-1-003 & 137 & 168 & 1 & 3.00 & 1.81 & 1.18 \\
\hline SNW-1-1 & 137 & 211 & 1 & 1.00 & 2.35 & -1.35 \\
\hline SNW-1-1 & 138 & 215 & 1 & 1.00 & 2.20 & -1.20 \\
\hline WEW-392 & 143 & 59 & 1 & 1.00 & 3.30 & -2.30 \\
\hline CHW-111 & 144 & 114 & 1 & 1.00 & 3.88 & -2.88 \\
\hline WEW-388 & 145 & 67 & 1 & 5.00 & 7.60 & -2.60 \\
\hline CHW-150 & 145 & 107 & 1 & 3.00 & 2.02 & .97 \\
\hline WEW-395 & 146 & 52 & 1 & 1.00 & 1.93 & -.92 \\
\hline WEW-389 & 146 & 63 & 1 & 3.00 & 3.61 & -.61 \\
\hline CHW-142 & 147 & 116 & 1 & 1.00 & 1.81 & -.81 \\
\hline CHW-143 & 148 & 115 & 1 & 3.00 & 2.05 & .95 \\
\hline CHW-192 & 156 & 104 & 1 & 3.00 & 1.80 & 1.20 \\
\hline \multicolumn{7}{|c|}{ Pawcatuck River Basin Observation Wells } \\
\hline SNW-1-98 & 43 & 246 & 1 & 98.00 & 101.44 & -3.44 \\
\hline SNW-1-97 & 53 & 233 & 1 & 97.00 & 94.41 & 2.59 \\
\hline CHW-305 & 55 & 150 & 1 & 54.00 & 59.19 & -5.19 \\
\hline CHW-285 & 55 & 164 & 1 & 65.00 & 63.23 & 1.77 \\
\hline CHW-154 & 56 & 149 & 1 & 57.00 & 55.63 & 1.37 \\
\hline CHW-307 & 62 & 165 & 1 & 70.00 & 78.39 & -8.39 \\
\hline SNW-1-136 & 65 & 247 & 1 & 136.00 & 134.50 & 1.50 \\
\hline CHW-255 & 67 & 177 & 1 & 83.00 & 83.19 & -.19 \\
\hline CHW-262 & 68 & 169 & 1 & 88.00 & 89.23 & -1.23 \\
\hline SNW-1-91 & 69 & 227 & 1 & 91.00 & 91.97 & -.97 \\
\hline SNW-1-146 & 69 & 243 & 1 & 146.00 & 130.35 & 15.65 \\
\hline SNW-1-141 & 69 & 248 & 1 & 141.00 & 158.34 & -17.34 \\
\hline CHW-226 & 70 & 132 & 1 & 43.00 & 43.77 & -.77 \\
\hline SNW-1-96 & 70 & 226 & 1 & 96.00 & 93.75 & 2.25 \\
\hline
\end{tabular}


Table 3. Measured water levels for selected observation wells in the modeled area (1954-61), and the model-calculated waterlevel altitudes for simulated current (1995-99) pumping and recharge conditions, South Coastal Basin aquifer, southern Rhode Island.-Continued

[Well locations shown on figure 10. ID: identifier. Residual: Residual equals measured minus model-calculated. Water-level values are in feet relative to NGVD29.]

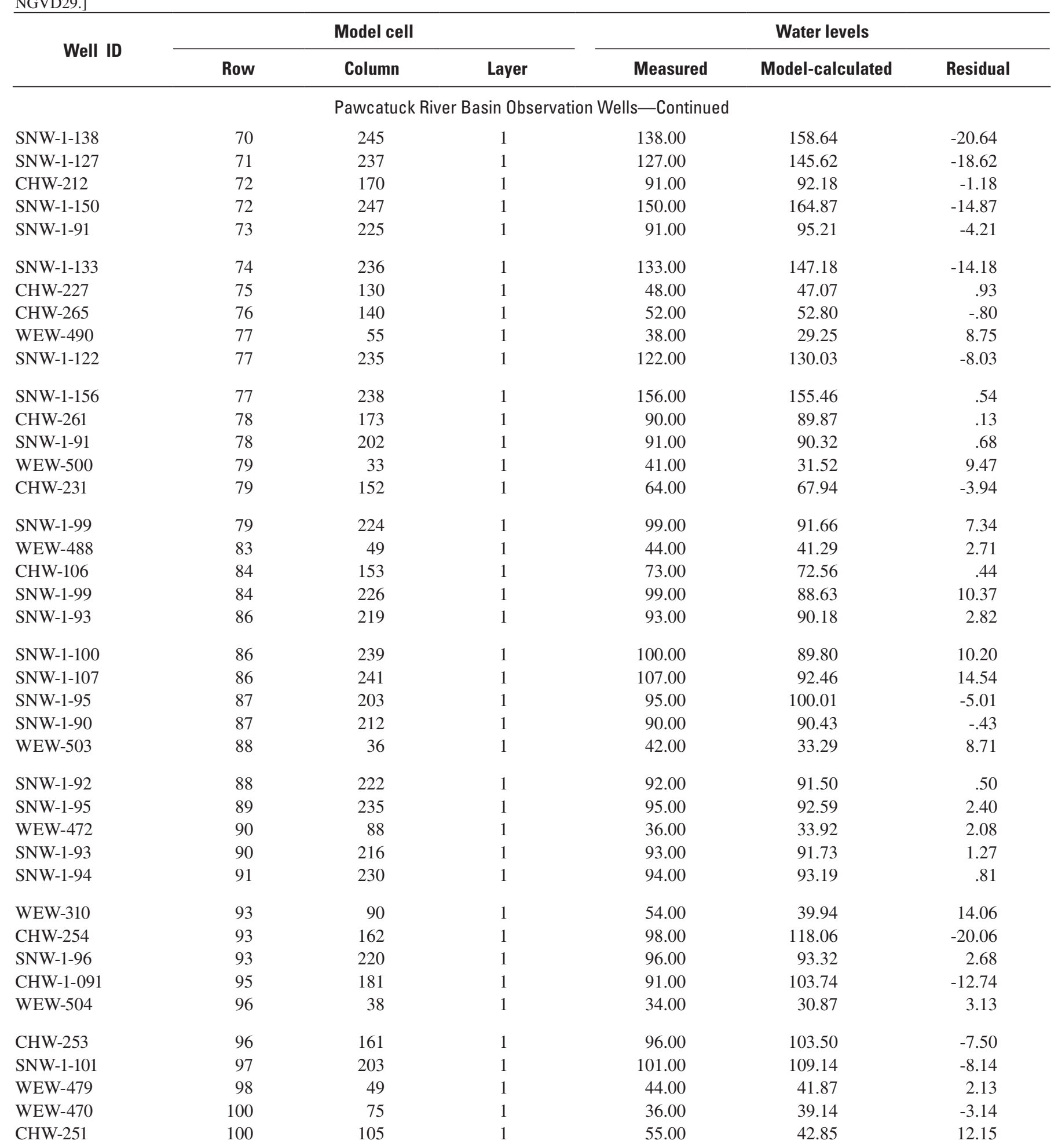


Table 3. Measured water levels for selected observation wells in the modeled area (1954-61), and the model-calculated waterlevel altitudes for simulated current (1995-99) pumping and recharge conditions, South Coastal Basin aquifer, southern Rhode Island.-Continued

[Well locations shown on figure 10. ID: identifier. Residual: Residual equals measured minus model-calculated. Water-level values are in feet relative to NGVD29.]

\begin{tabular}{|c|c|c|c|c|c|c|}
\hline Well ID & \multicolumn{3}{|c|}{ Model cell } & \multicolumn{3}{|c|}{ Water levels } \\
\hline \multicolumn{7}{|c|}{ Pawcatuck River Basin Observation Wells_-Continued } \\
\hline HOW-197 & 102 & 62 & 1 & 36.00 & 30.27 & 5.73 \\
\hline WEW-469 & 105 & 74 & 1 & 36.00 & 41.16 & -5.16 \\
\hline CHW-016 & 108 & 132 & 1 & 39.00 & 40.63 & -1.63 \\
\hline WEW-341 & 111 & 30 & 1 & 17.00 & 15.07 & 1.93 \\
\hline WEW-358 & 117 & 58 & 1 & 34.00 & 34.29 & -.29 \\
\hline WEW-352 & 117 & 71 & 1 & 41.00 & 39.61 & 1.39 \\
\hline WEW-426 & 119 & 29 & 1 & 42.00 & 36.34 & 5.66 \\
\hline WEW-356 & 119 & 63 & 1 & 34.00 & 35.32 & -1.32 \\
\hline CHW-245 & 123 & 109 & 1 & 67.00 & 64.06 & 2.93 \\
\hline WEW-349 & 125 & 66 & 1 & 34.00 & 36.39 & -2.39 \\
\hline WEW-300 & 125 & 96 & 1 & 121.00 & 98.29 & 22.70 \\
\hline WEW-401 & 126 & 49 & 1 & 37.00 & 38.20 & -1.20 \\
\hline CHW-246 & 126 & 109 & 1 & 64.00 & 66.66 & -2.66 \\
\hline WEW-412 & 127 & 30 & 1 & 1.00 & 10.97 & -9.97 \\
\hline WEW-293 & 127 & 89 & 1 & 106.00 & 100.62 & 5.38 \\
\hline WEW-413 & 129 & 36 & 1 & 32.00 & 32.59 & -.59 \\
\hline WEW-417 & 142 & 22 & 1 & 1.00 & 5.05 & -4.05 \\
\hline
\end{tabular}





\section{Appendix 1}

Use of Continuous Resistivity-Profiling Techniques to Characterize the Freshwater Beneath the Coastal Waters of the Salt Pond Region of Southern Rhode Island 


\section{Contents}

Use of Continuous Resistivity-Profiling Techniques to Characterize the Freshwater Beneath the Coastal Waters of the Salt Pond Region of

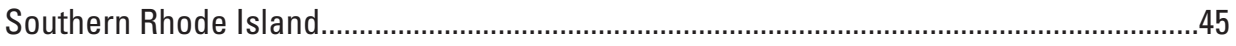

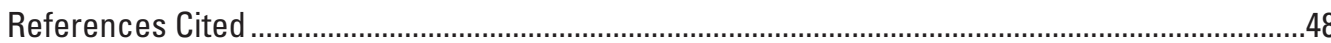

\section{Figures}

1-1. Diagram showing continuous resistivity-profiling technique

1-2. Photograph showing pontoon boat and water-quality sampling equipment for measurements made in Ninigret Pond, southern Rhode Island, along section $C$ - $C^{\prime}$ (figure 1-4)

1-3. Map showing section lines of continuous resistivity profiling in Ninigret and Green Hill Ponds. Sections are shown in figures 1-4, 1-5, and 1-9.

1-4-1-5. Sections showing:

1-4. Continuous resistivity profiling with salinities measured at three sampling locations along line $C$ - $C^{\prime}$ in the Fort Neck section of Ninigret Pond.

Sections are shown on figure 1-3

1-5. Continuous resistivity profiling $D-D^{\prime}, E-E^{\prime}$, and $F-F^{\prime}$ in Ninigret Pond. Sections are shown on figure 1-3.

1-6. Map showing section lines of continuous resistivity profiling in Winnapaug and

Quonochontaug Ponds. Sections are shown in figures 1-7 and 1-8

1-7-1-9. Sections showing:

1-7. Continuous resistivity profiling $J-J^{\prime}, K-K^{\prime}$, and $L-L^{\prime}$ in Winnapaug Pond. Sections are shown on figure 1-6.

1-8. Continuous resistivity profiling $M-M^{\prime}, N-N^{\prime}$, and $0-O^{\prime}$ in Quonochontaug Pond. Sections are shown on figure 1-6

1-9. Continuous resistivity profiling $G-G^{\prime}$ and $H-H^{\prime}$ in Green Hill Pond. Sections are shown on figure 1-3.

1-10. Map showing section lines of continuous resistivity profiling in Point Judith Pond. Sections are shown in figure 1-11

1-11. Section showing continuous resistivity profiling $P-P^{\prime}$ and $Q-Q^{\prime}$ in Point Judith Pond.

Sections are shown on figure 1-10. 


\section{Appendix 1}

\section{Use of Continuous Resistivity- Profiling Techniques to Characterize the Freshwater Beneath the Coastal Waters of the Salt Pond Region of Southern Rhode Island}

A geophysical technique known as continuous resistivity profiling (CRP) was used in this investigation to characterize the offshore extent of the ground-water discharge (submarine ground-water discharge) beneath the coastal waters. CRP surveys were made in the salt ponds and along the shoreline of the Atlantic Ocean south of the salt ponds to detect freshwater in the subsurface and to improve the understanding of submarine ground-water discharge in these offshore areas.

In the CRP surveys, the seaward extent of submarine ground-water discharge is determined on the basis of the apparent resistivity in the subsurface beneath nearshore coastal waters (Manheim and others, 2004; Masterson, 2004). The CRP technique is based on the premise that, although resistivity is a function of the subsurface lithology, porosity, and pore-water salinity, freshwater-saturated sediments will have a much higher resistivity than similar sediments saturated with saltwater.

CRP surveys consist of towing an array of electrodes that inject an electrical current every 3 seconds and measuring the resulting electric potential at several depths as it is towed behind a boat (fig. 1-1). The surveys provide the opportunity to collect data over large areas in a relatively short period of time (for example, several miles per day).

The measurement depth of the electrical signal in the CRP surveys depends on the distance between electrodes and, to some extent, the subsurface lithology (Manheim and others, 2004), but is typically about 20 percent of the electrodespacing length. In this investigation, 160-ft and $360-\mathrm{ft}$ long streamers consisting of 11 stainless-steel electrodes spaced $6 \mathrm{ft}$ apart provided data from measurement depths of about 43 and $89 \mathrm{ft}$, respectively. Once the CRP data were collected, the postprocessing of these apparent resistivity profiles was done by an inversion-modeling technique in which the raw data, water depth, and global-positioning data were synchronized and subdivided into linear sections. A more detailed descrip-

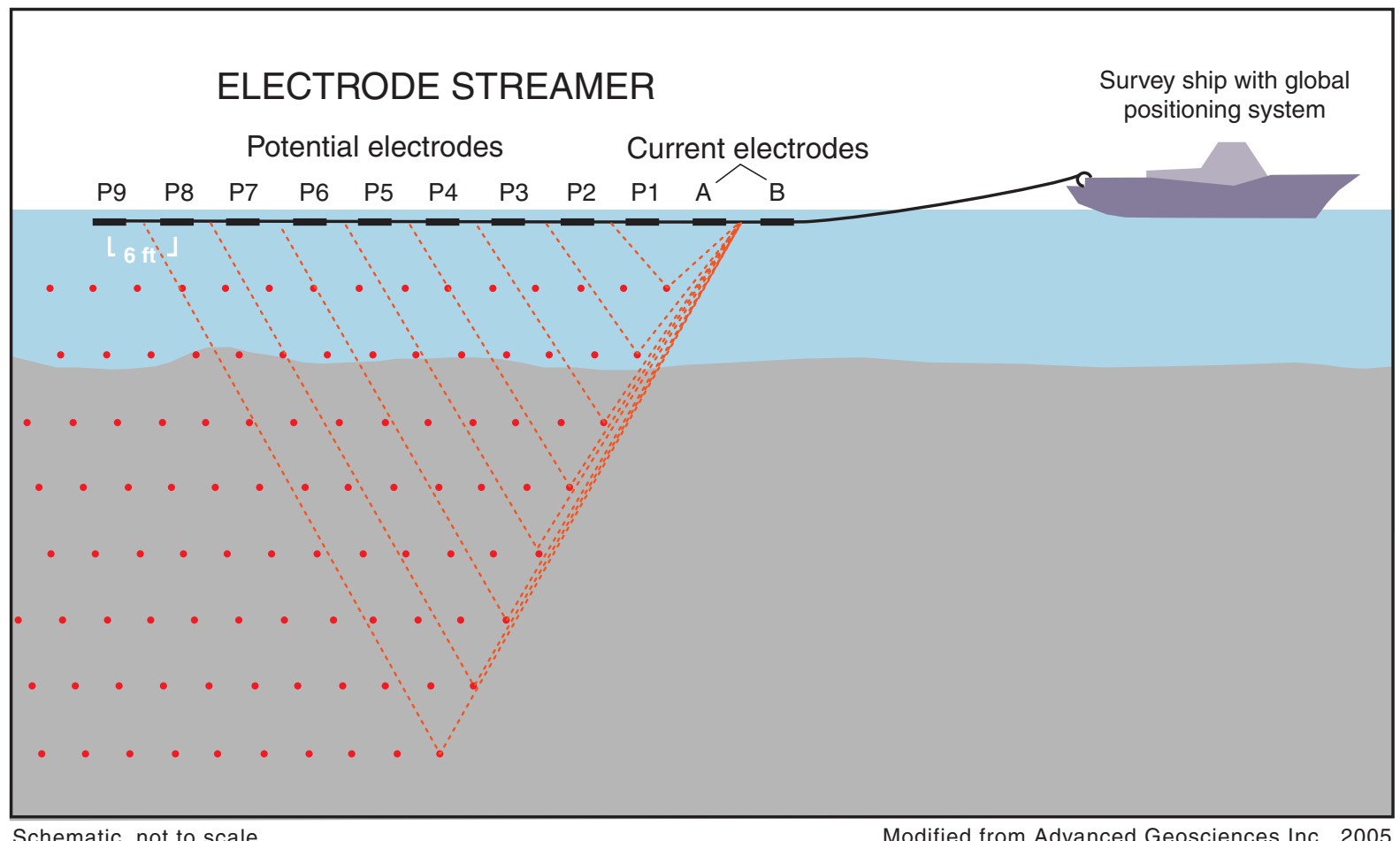

1-1. Diagram showing continuous resistivity-profiling technique. 


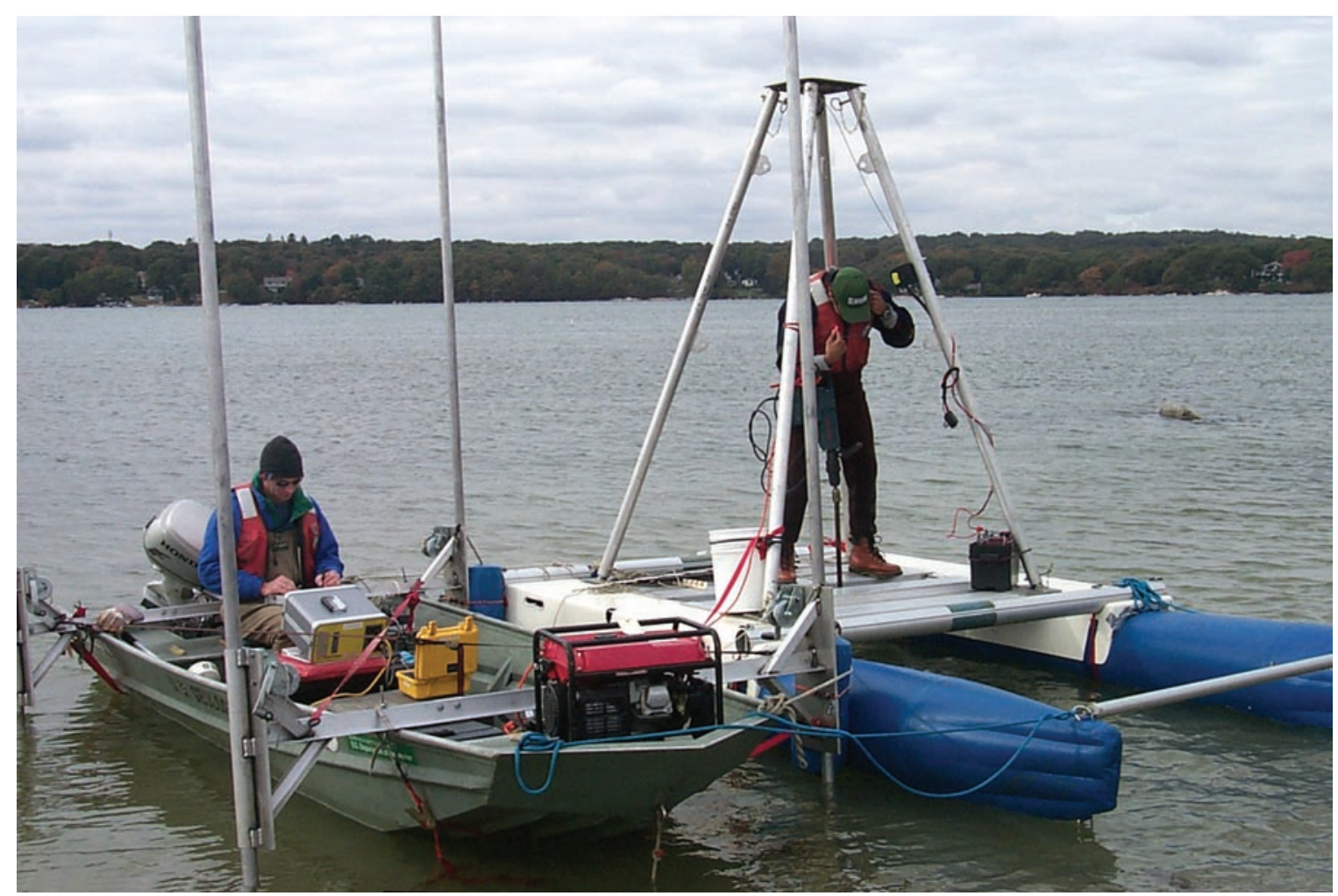

1-2. Pontoon boat and water-quality sampling equipment for measurements made in Ninigret Pond, southern Rhode Island, along section $C$ - $C^{\prime}$ (figure 1-4).

tion of the CRP methodology can be found Snyder and Wightman (2002) and Manheim and others (2004).

Interpretation of the postprocessed CRP sections requires an understanding of the hydrogeologic setting, as well as the issues inherent to the inversion software. For instance, the measurement depth seen in the profiles was not measured directly during the data-collection process but instead was calculated by the inversion-coding software. The calculated depths could be affected by the conditions under which the data were collected (such as weather conditions, subsurface lithology, and electrode oxidation).

Because of the issues associated with the processing of the CRP sections, pore-water samples also were collected at selected locations to verify the modeled resistivity values. The samples were collected by using a drive-point sampling method previously used on Ashumet Pond and Red Brook Harbor, Cape Cod, MA (McCobb and LeBlanc, 2002; McCobb and others, 2003). The equipment includes a steel pipe with a 0.625-in-diameter, slotted-steel temporary wellpoint sampler, which was driven into the pond-bottom sediments by a jackhammer from a pontoon-type boat equipped with a stable working deck, four-legged support frame, and retraction winch (fig. 1-2).

Once the sampling screen was driven to the desired depth, the drive pipe was pulled back to expose the slotted well screen. After the well screen was exposed, a 3/16-in- diameter polyethylene tube was slipped down the inside of the drive pipe to the depth of the exposed 0.85-ft-long slotted screen, and a peristaltic pump was used to pump ground water from the sand and gravel sediments in the subsurface. After several volumes of the tubing were purged through the pump, measurements of salinity and specific conductance were made with a hand-held multimeter until these values remained constant.

The drive-point sampler was driven through the soft fine-grained silt and clay sediments into the underlying coarsegrained sands and gravel. This depth was generally about 20-25 ft below the pond bottom at the three locations where measurements were made (fig. 1-3). These pore-water values were compared to the modeled resistivity values calculated for the CRP section shown on figure 1-4. The section labeled $C$ to $C^{\prime \prime}$ (fig. 1-3) in Ninigret Pond had a maximum penetration depth of about $43 \mathrm{ft}$ and resistivity values ranging from 0.3 ohm-meter $(\Omega-\mathrm{m})$ in the saline surface water to $7 \Omega-\mathrm{m}$ in the subsurface (fig. 1-4). The modeled resistivity values increased with depth; in the upper 20 to $25 \mathrm{ft}$ of the pond-bottom subsurface, the values ranged from 0.1 to $3 \Omega-\mathrm{m}$. At depths greater than $25 \mathrm{ft}$, the values increased to a maximum of about $7 \Omega-\mathrm{m}$ (light blue areas, fig. 1-4).

A previous investigation in Ninigret Pond determined that the upper $20 \mathrm{ft}$ of subsurface sediments consists of organics and fine-grained materials such as clays, silts, and fine sands 


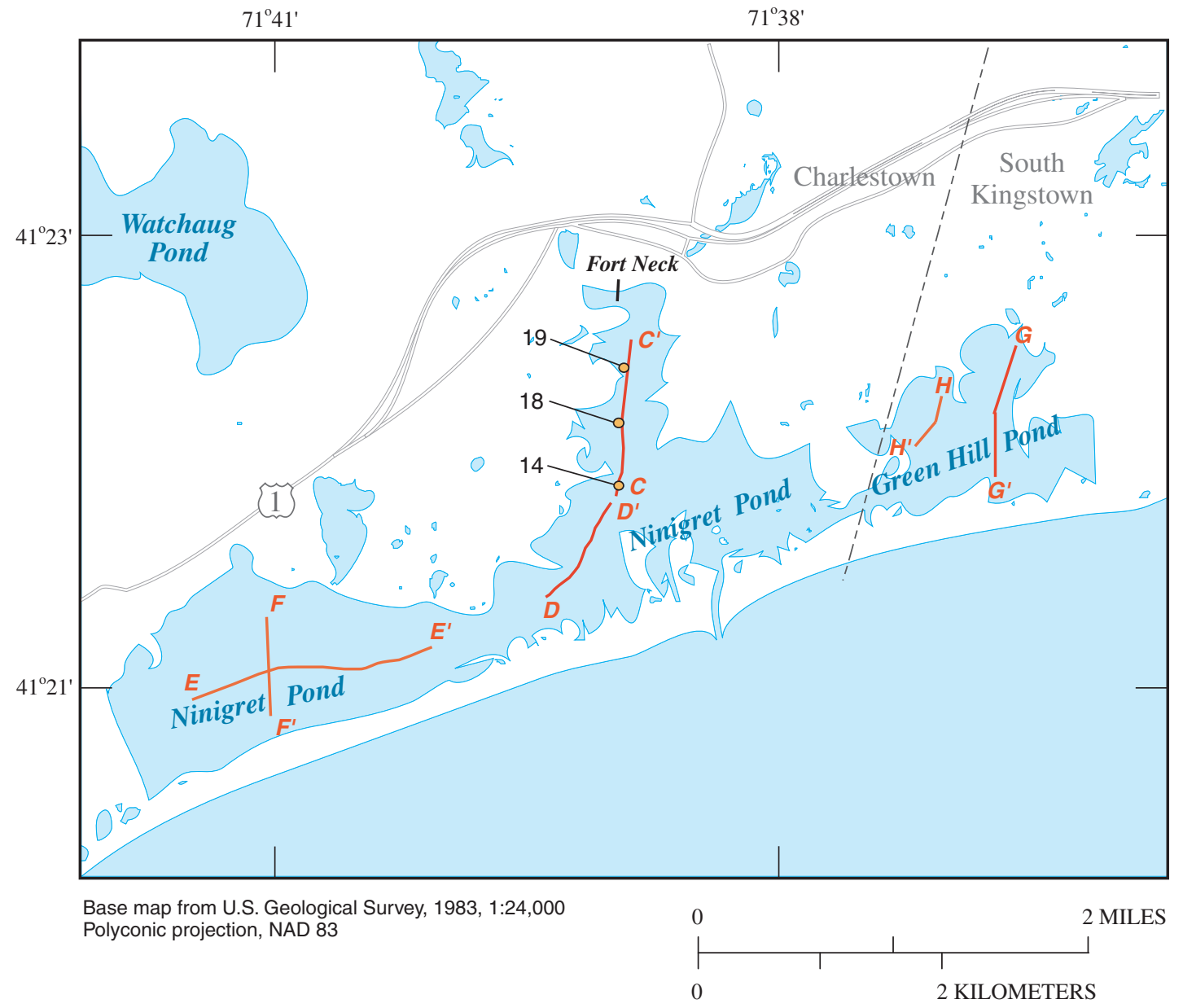

EXPLANATION

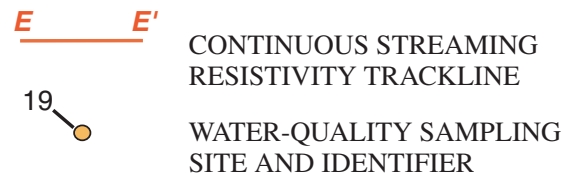

1-3. Section lines of continuous resistivity profiling in Ninigret and Green Hill Ponds, southern Rhode Island. Sections are shown in figures 1-4, 1-5, and 1-9.

saturated with saline water (Dillon, 1970). At a depth of about $25 \mathrm{ft}$ below the pond bottom, the lithology changes from a fine-grained material to poorly sorted coarse-grained sands and gravel (fig. 5). Beneath the coarse-grained deposits is the underlying crystalline bedrock that is inferred to be about 100 $\mathrm{ft}$ below the pond bottom in this area (fig. 3).

Results of the CRP surveys conducted in Ninigret Pond suggest that the pond appears to be completely underlain by freshwater. The large contrast in modeled resistivity values $(0.3-7 \Omega-m)$ in areas inferred to be shallower than the regional bedrock surface indicate that a contrast in pore-water salinity, rather than a change in the subsurface lithology, is the primary controlling factor of resistivity magnitudes. Manheim and others (2004) analyzed the effect of changes in lithology on the modeled resistivity values and determined that changes in lithology would account for only as much as a four-fold change in resistivity. This effect of the subsurface lithology on the modeled resistivity is referred to as the formation factor. Therefore, the large changes (greater than 20X) in modeled resistivity in the CRP sections of Ninigret Pond are most likely the result of changes in pore-water salinity rather than changes in subsurface lithology.

The pore-water samples collected along the CRP section $C$ to $C^{\prime}$ (fig. 1-4) confirmed that the green-shaded areas (modeled resistivity values between 2-4 $\Omega$-m) represent brackish water. The dark green to light blue areas on the section are assumed to represent fresher ground water beneath the ponds; however, no pore-water samples were obtained 


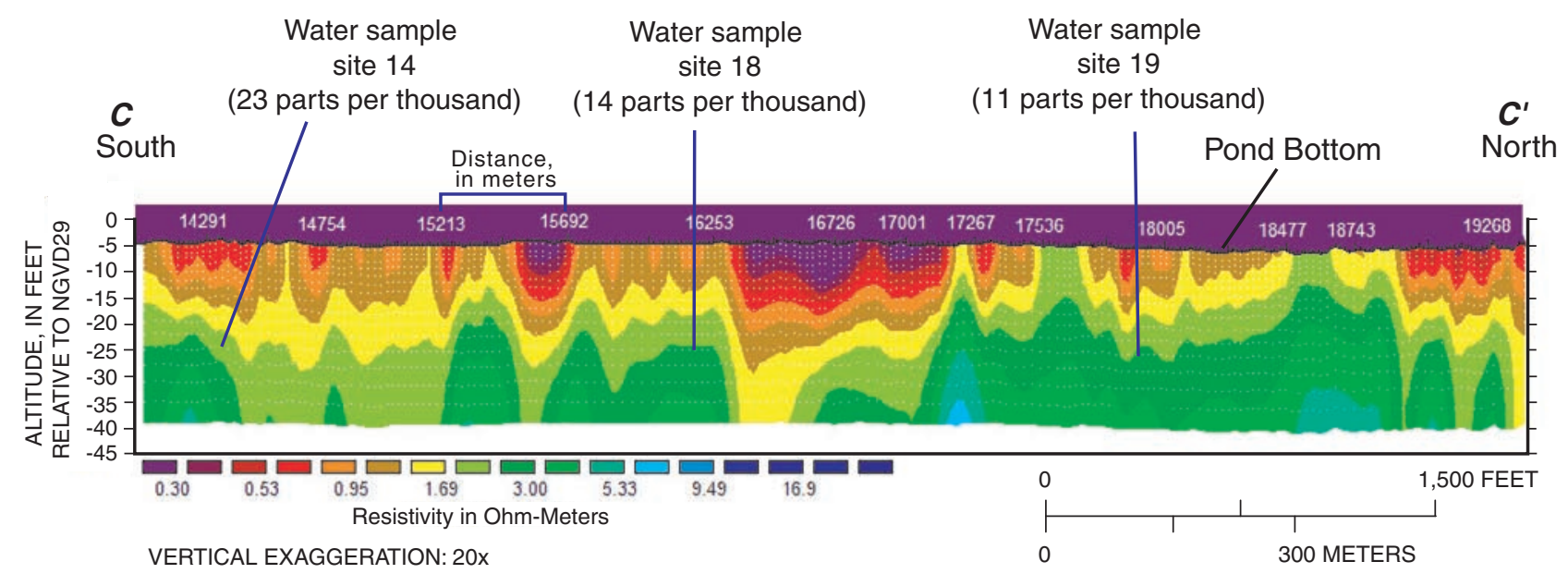

1-4. Continuous resistivity profiling with salinities measured at three sampling locations along line $C$ - $C^{\prime}$ in the Fort Neck section of Ninigret Pond, in southern Rhode Island. Sections are shown on figure 1-3.

from these deeper areas to confirm this hypothesis. It was therefore assumed that in areas where the modeled resistivity shown on the CRP sections exceeds $3 \Omega$-m, and no other lithologic evidence is available, freshwater is beneath the ponds (E.A. White, U.S. Geological Survey, oral commun., 2005).

The purpose of establishing this relation between porewater samples and the CRP modeled resistivity values was to qualitatively assess whether changes in modeled resistivity in the CRP sections represent changes in salinity in the subsurface beneath the ponds; a similar relation was established by Manheim and others (2004). The relation between the measured pore-water salinity and the resistivity values calculated from the inverse modeling process in section $C$ - $C^{\prime}$ was then applied to CRP sections from similar hydrogeologic settings throughout the salt ponds where pore-water samples were not available for comparison.

The salinity of ground water increases as the water flows from the northern shores of the ponds to the coast (Barlow, 2003). Thus, in the Salt Pond region, the areas most likely to have freshwater in the subsurface would be the northern shores of the ponds.

In the southwestern part of Ninigret Pond (section $F$ to $F^{\prime}$, figs. 1-3, 1-5), however, the resistivity values at the northern end of the section were much lower than those found in the CRP section in the northeastern area of the pond (section $C$ to $C^{\prime}$, fig. 1-4). A possible explanation for this is that the shallow saltwater-saturated fine-grained clay and silt deposits found throughout the pond extend deeper into the subsurface in this area than in other areas and the freshwater that underlies the fine-grained sediments is below the maximum mea- surement limit for the CRP equipment. Another geophysical technique-seismic reflection profiling - would have been useful in assessing the thickness of these fine-grained deposits; however, this area of the pond was too shallow to conduct these surveys.

The CRP sections of surveys collected in Winnapaug, Quonochontaug, Green Hill, and Point Judith Ponds are shown in figures 1-6 through 1-11. The CRP sections in Winnapaug, Green Hill, and Point Judith Ponds generally showed a distribution of modeled resistivity values similar to those collected in Ninigret Pond, indicating that although the surface waters of these ponds are saline, the subsurface sediments appear to be saturated with freshwater (figs. 1-7, 1-9, 1-11). The CRP sections did not show areas where freshwater is discharging to the ponds through the pond bottom, only that freshwater appears to be present in the subsurface beneath the ponds. Determining areas where ground water may be discharging into a given pond would require a detailed pond-scale level investigation, which was beyond the scope of this regional analysis.

In the case of Quonochontaug Pond, where the depth to bedrock is shallow (Hermes and others, 1994), and where bedrock is exposed in some areas within the pond (as seen on fig. 3), the freshwater is most likely flowing through fractures in the underlying bedrock rather than the overlying unconsolidated sediments. As a result, the saltwater-saturated finegrained sediments directly overlie bedrock with no intervening freshwater-saturated coarse-grained sand and gravel deposits, as seen in the other salt ponds (sections $N-N^{\prime}$ and $O-O^{\prime}$, fig. 1-8). 

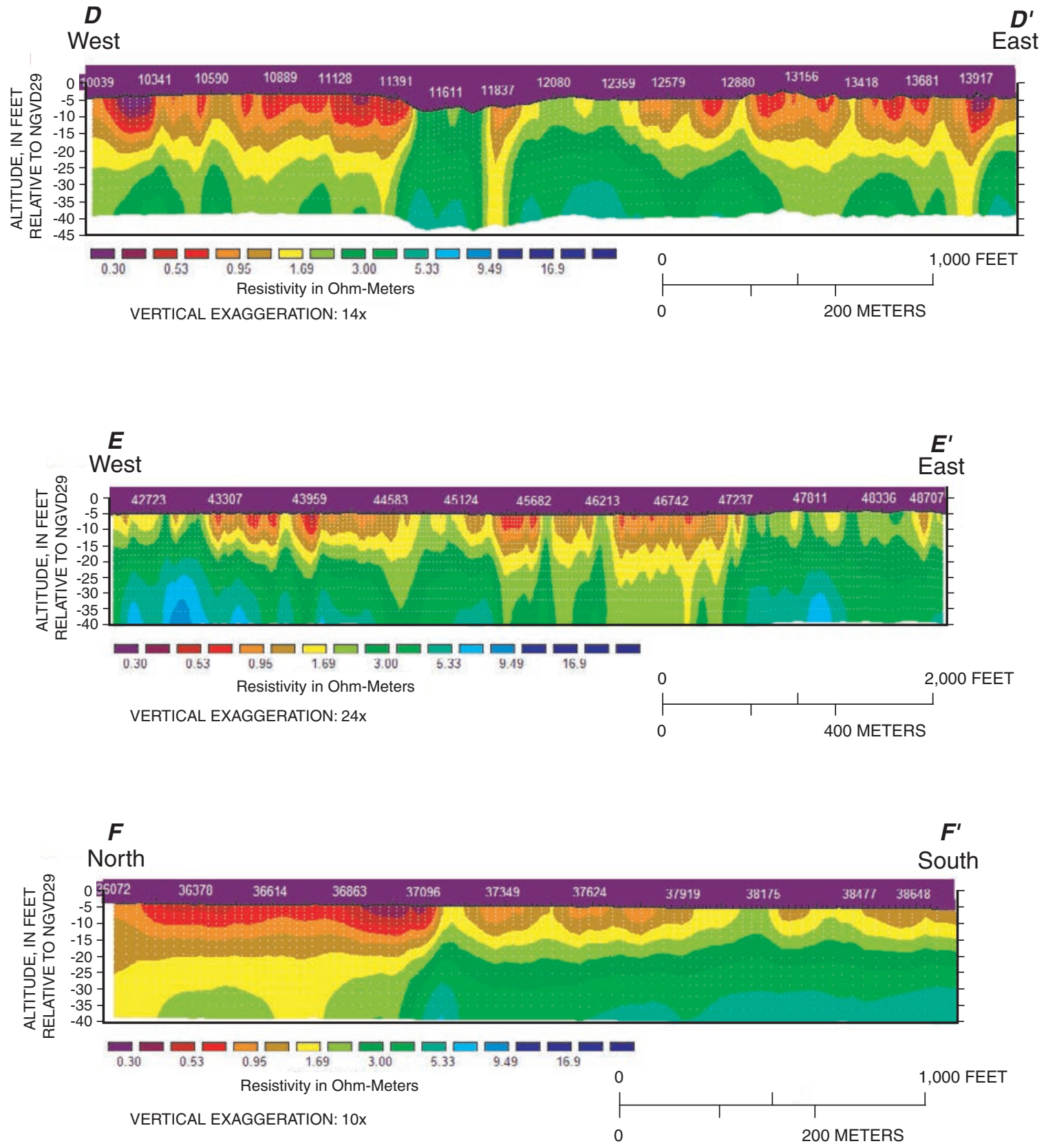

1-5. Continuous resistivity profiling $D-D^{\prime}, E-E^{\prime}$, and $F-F^{\prime}$ in Ninigret Pond, southern Rhode Island. Sections are shown on figure 1-3. 


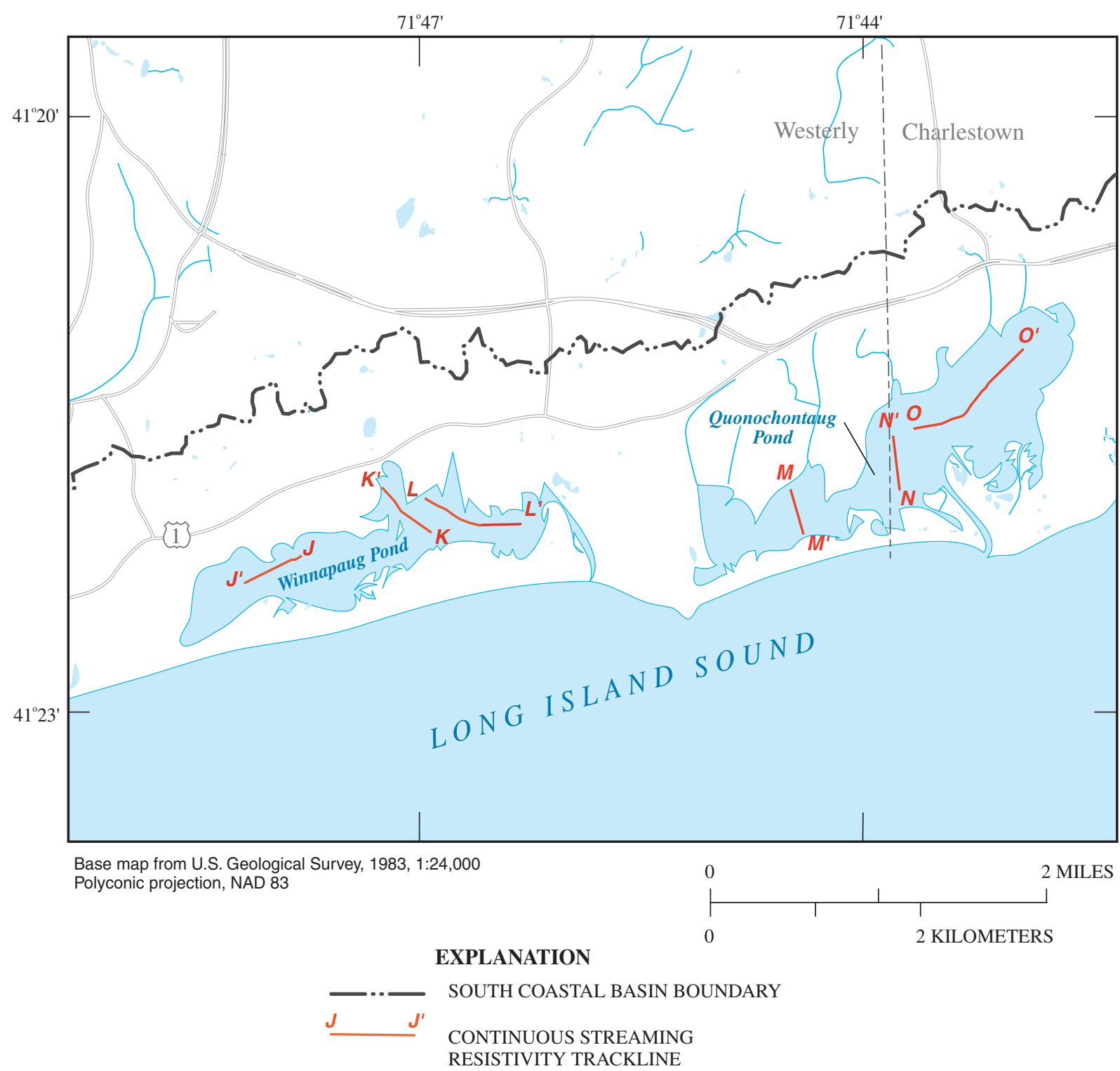

1-6. Section lines of continuous resistivity profiling in Winnapaug and Quonochontaug Ponds, southern Rhode Island. Sections are shown in figures 1-7 and 1-8.

Unlike the CRP surveys in the salt ponds, the CRP survey conducted along the Atlantic Ocean coastline offshore from Quonochontaug to Point Judith Ponds (not shown in report) did not detect freshwater in the subsurface (to a depth of approximately $50 \mathrm{ft}$ ). Whether this finding indicates that the trackline was beyond the seaward-most extent of submarine ground-water discharge in the study area, or that freshwater is deeper in the subsurface than the maximum penetration depth of the CRP equipment, could not be determined from this analysis. Therefore, for the purpose of this investigation, it was assumed that all the salt ponds are underlain by freshwater and that the seaward extent of submarine ground- water discharge is along the coast between the Atlantic Ocean shoreline and the position of the offshore CRP track line.

The geophysical surveys described in this section were conducted to improve the understanding of ground-water flow and discharge into and beneath the salt ponds. The CRP technique is a useful tool to detect the presence of submarine ground-water discharge in offshore coastal waters and to help direct more detailed investigations, but it cannot quantify the amount of discharge in these coastal waters. The information obtained from the CRP surveys was used to develop the ground-water-flow model, which was then used to quantify ground-water discharge into the salt ponds. 

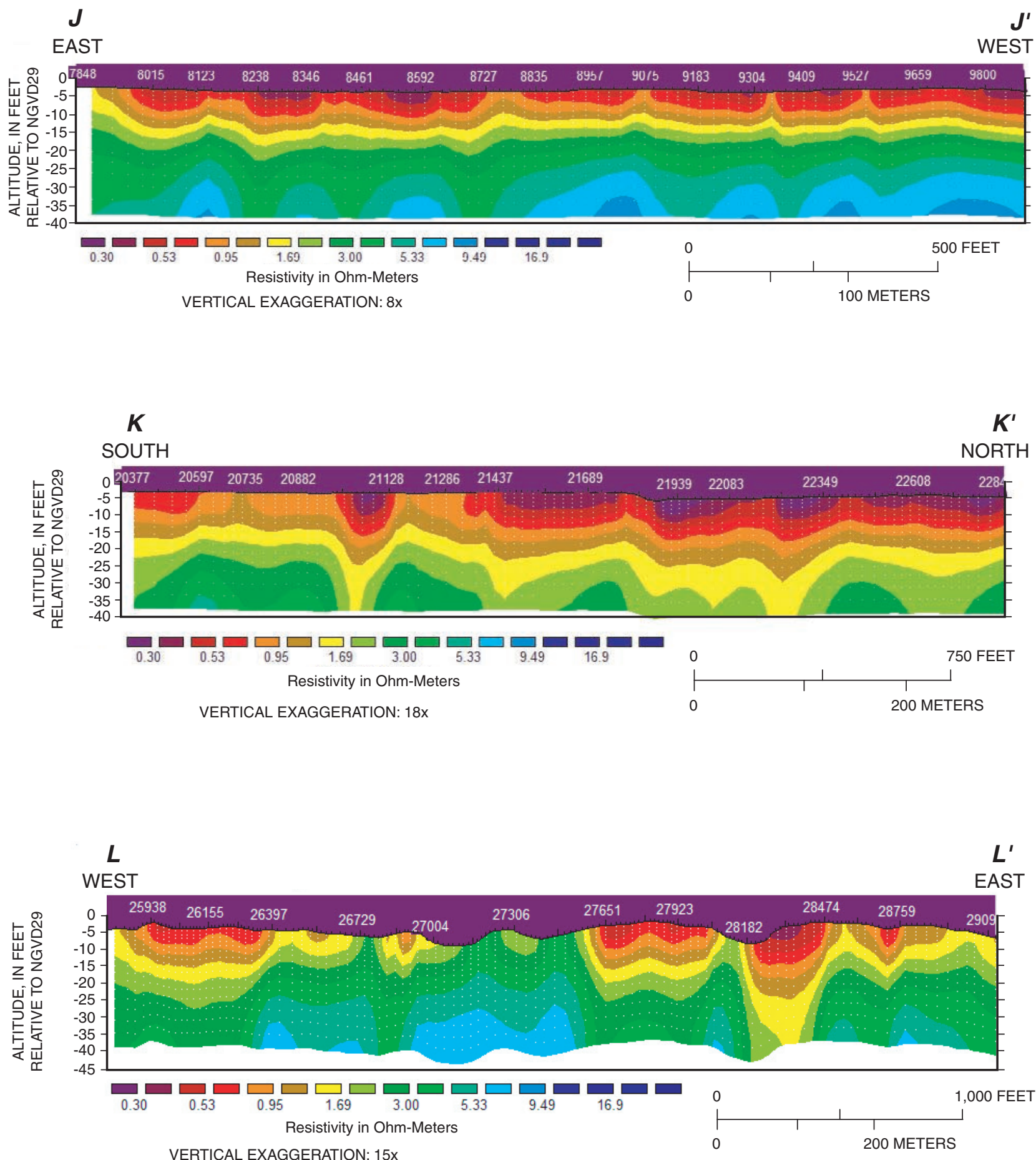

1-7. Continuous resistivity profiling $J-J^{\prime}, K-K^{\prime}$, and $L-L^{\prime}$ in Winnapaug Pond, southern Rhode Island. Sections are shown on figure 1-6. 

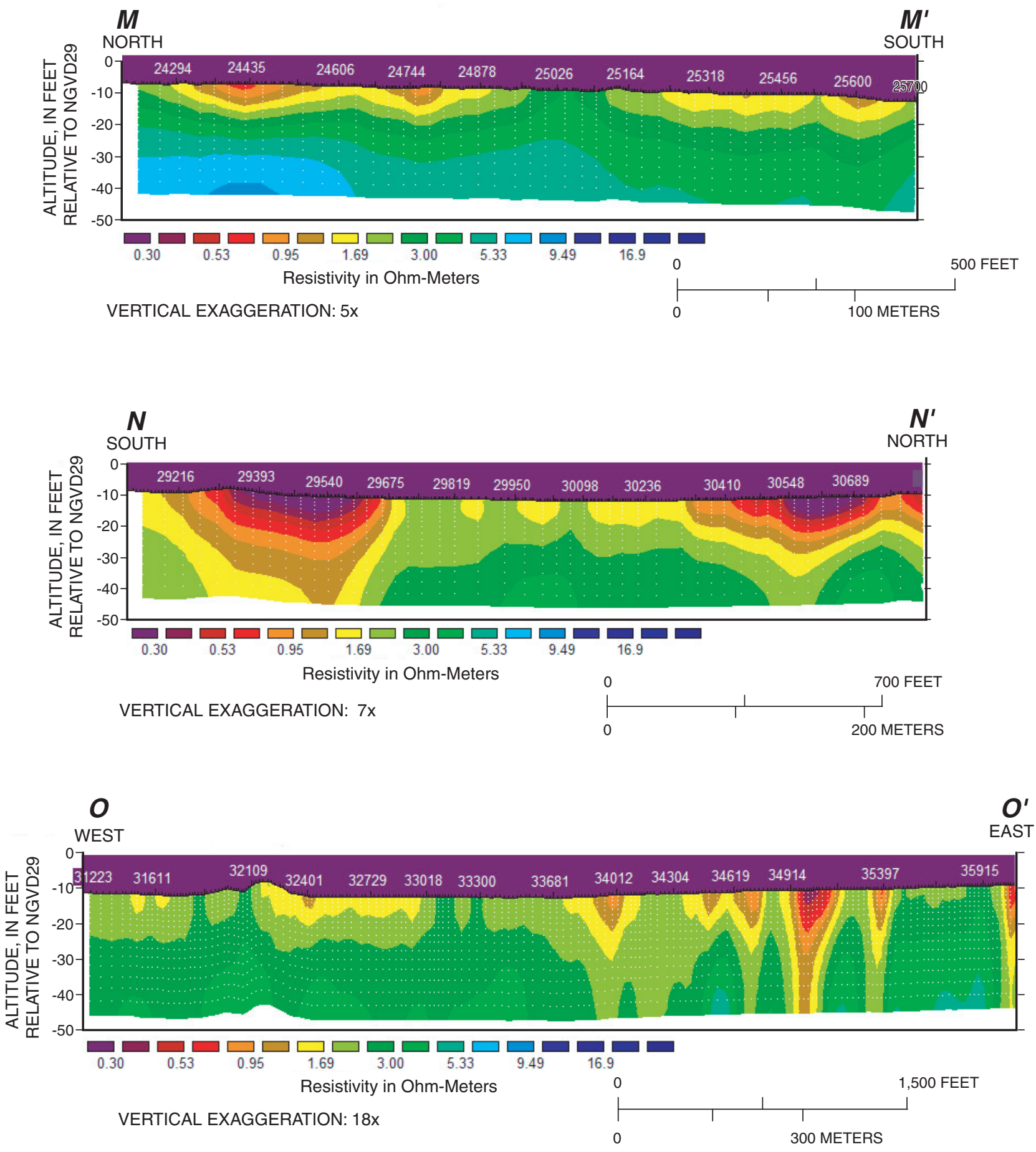

1-8. Continuous resistivity profiling $M-M^{\prime}, N-N^{\prime}$, and $O-O^{\prime}$ in Quonochontaug Pond, southern Rhode Island, Sections are shown on figure 1-6. 
G

NORTH

SOUTH
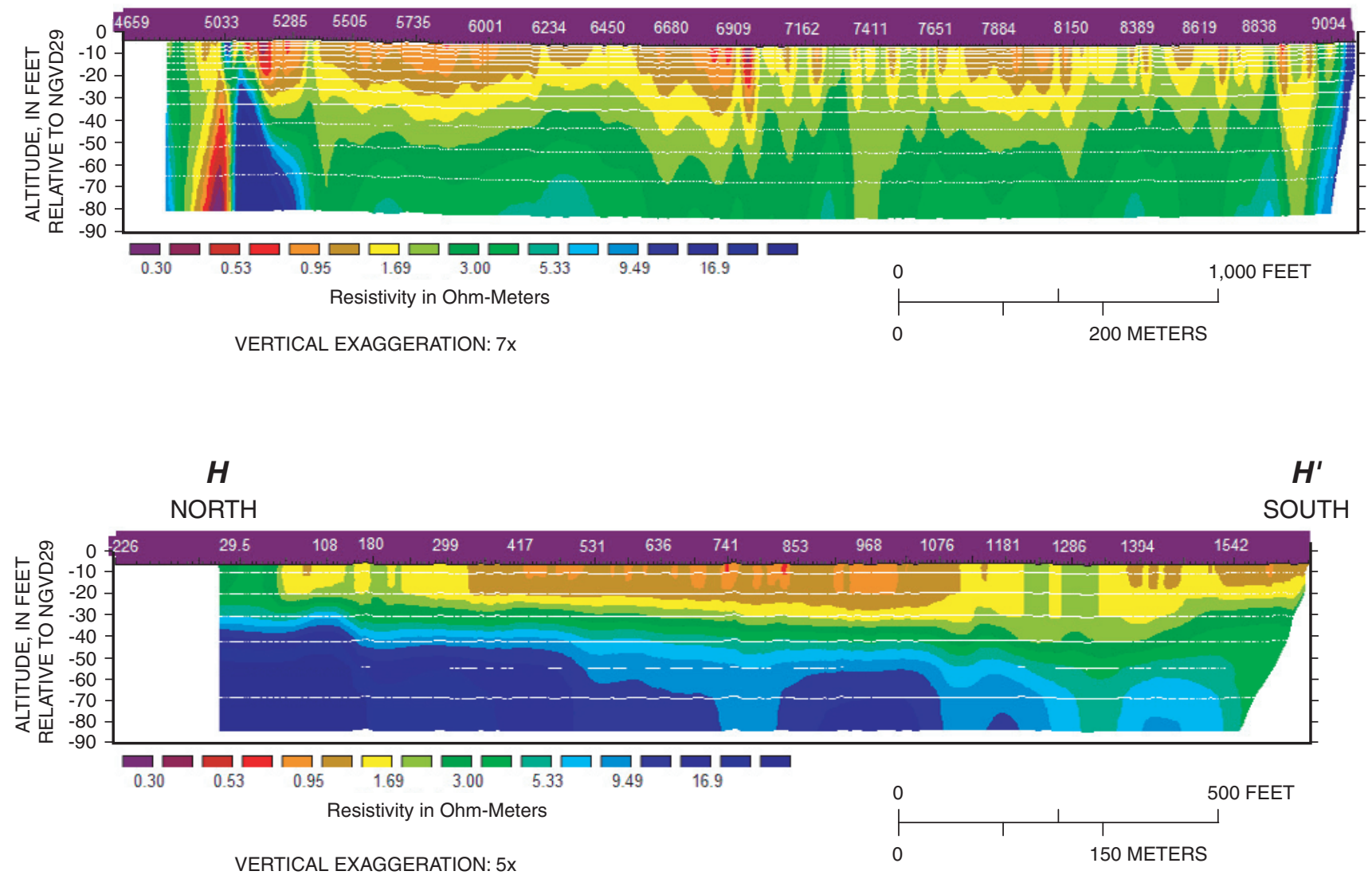

1-9. Continuous resistivity profiling $G-G^{\prime}$ and $H-H^{\prime}$ in Green Hill Pond, southern Rhode Island. Sections are shown on figure 1-3. 


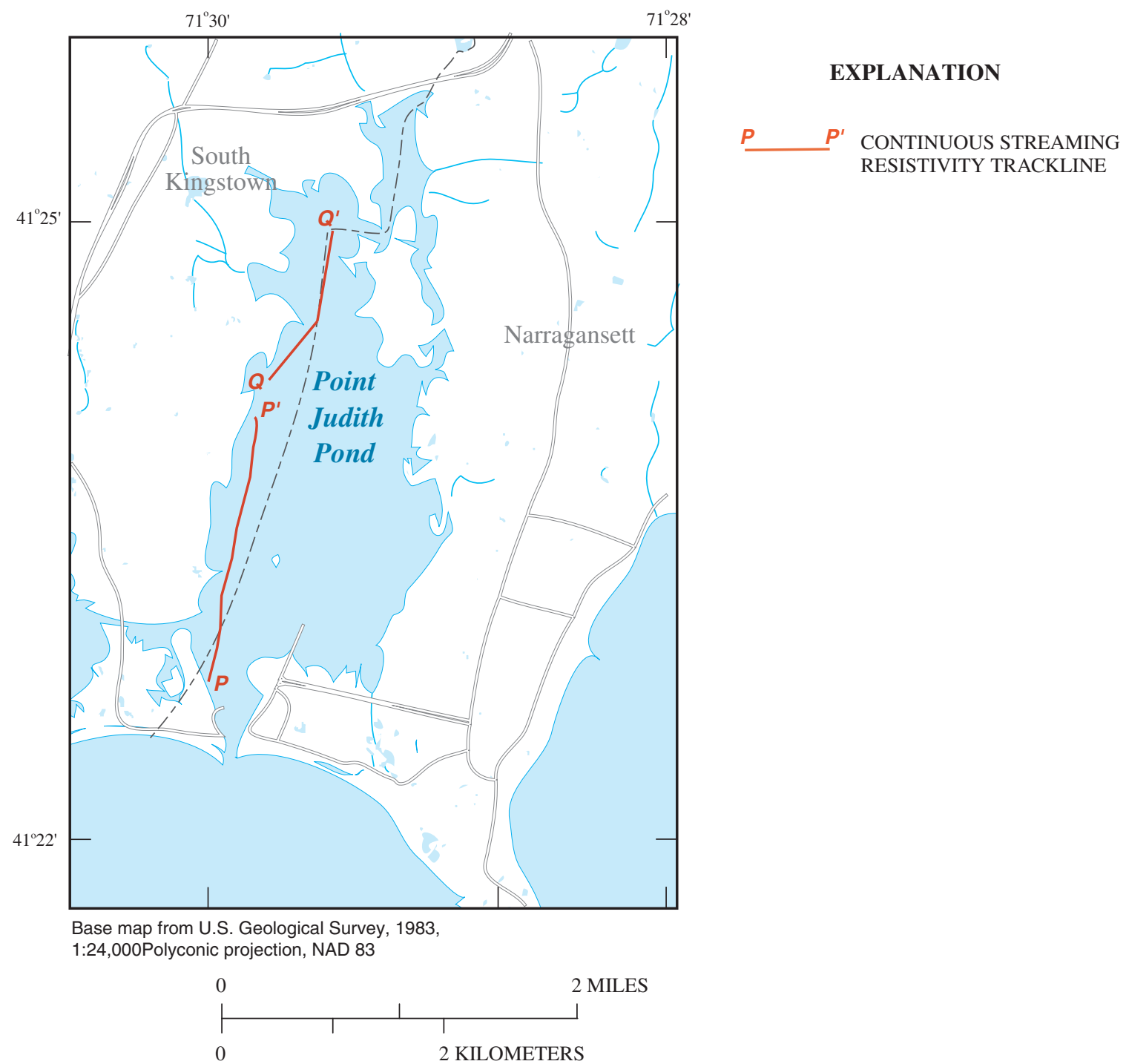

1-10. Section lines of continuous resistivity profiling in Point Judith Pond, southern Rhode Island. Sections are shown in figure 1-11. 

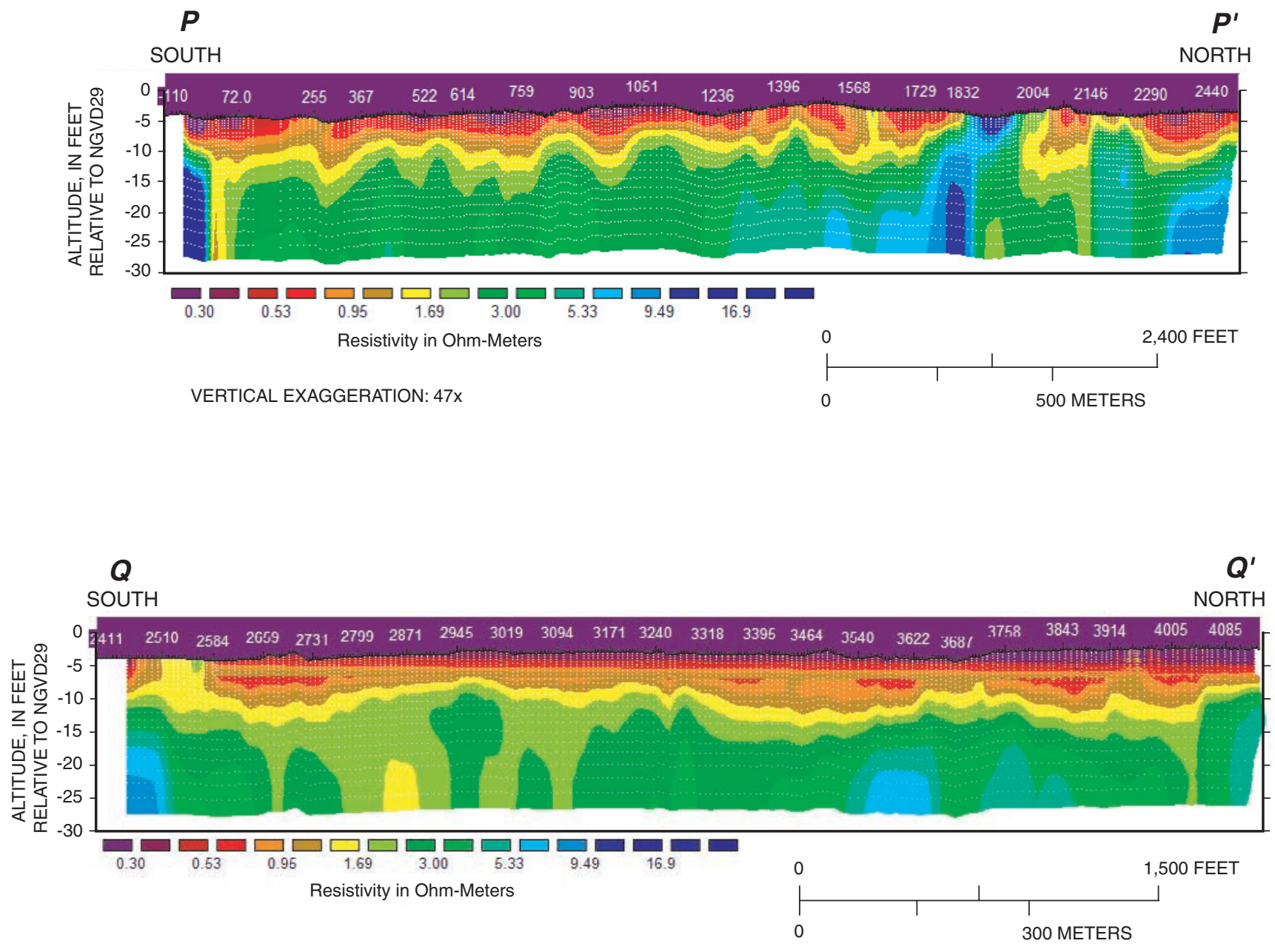

VERTICAL EXAGGERATION: 26x

1-11. Continuous resistivity profiling $P-P^{\prime}$ and $Q-Q^{\prime}$ in Point Judith Pond, southern Rhode Island. Sections are shown on figure 1-10. 


\section{References Cited}

Advanced Geosciences, Inc., 2005, SuperSting R8 Marine Logging System - Online Brochure: accessed June 8, 2005, at http://www.agiusa.com/marinesystem.shtml

Barlow, P.M., 2003, Ground water in freshwater-saltwater environments of the Atlantic Coast: U.S Geological Survey Circular 1262, $113 \mathrm{p}$.

Dillon, W.P., 1970, Submergence effects on a Rhode Island barrier and lagoon and inferences on migration of barriers: Journal of Geology, v. 78, p. 94-106.

Hermes, O.D., Gromet, L.P., and Murray, D.P., comps., 1994, Bedrock geologic map of Rhode Island: Rhode Island Map Series No. 1, University of Rhode Island, Kingston, scale 1:100,000.

Manheim, F.T., Krantz, D.E., and Bratton, J.F., 2004, Investigations of submarine ground-water discharge in Delmarva coastal bays by horizontal resistivity surveying and ancillary techniques, in McKenna, T.E., and Martin J.B., eds., Ground water discharge to estuarine and coastal ocean environments: Ground Water, v. 42, no. 7, p. 1-17.
Masterson, J.P., 2004, Simulated interaction between freshwater and saltwater and effects of ground-water pumping and sea-level change, Lower Cape Cod aquifer system, Massachusetts: U.S. Geological Survey Scientific Investigations Report 2004-5014, 78 p.

McCobb, T.M., and LeBlanc, D.R., 2002, Detection of fresh ground water and a contaminant plume beneath Red Brook Harbor, Cape Cod, Massachusetts, 2000: U.S. Geological Survey Water-Resources Investigations Report 02-4166, $36 \mathrm{p}$.

McCobb, T.M., LeBlanc, D.R., Walter, D.A., Hess, K.M., Kent, D.B., and Smith R.L., 2003, Phosphorus in a groundwater contaminant plume discharging to Ashumet Pond, Cape Cod, Massachusetts, 1999: U.S. Geological Survey Water-Resources Investigations Report 02-4306, 69 p.

Snyder, D.D., and Wightman, W.E., 2002, Application of continuous resisitivity profiling to aqueous characterization, in Proceeding of the Symposium on the Application of Geophysics to Environmental and Engineering Problems (SAGEEP), February 10-14, 2002, Las Vegas, Nevada, Paper 13 GSL. 
For more information contact:

Deputy Director

USGS Massachusetts-Rhode Island

Water Science Center, Rhode Island Office

275 Promenade Street, Suite 150

Providence, RI 02908

or visit our Web site at

http://ri.water.usgs.gov 